\title{
Brothers in Arms: Soldiers in Early Christianity
}

So far as our sources permit us to judge, this kind of career has little or no relevance for the first generations of Christians, although later on Christians in the army would constitute a problem both for the empire and for the church's leaders. ${ }^{1}$

This is what Wayne A. Meeks has to say about Christian soldiers in his groundbreaking study First Urban Christians (1983), which mapped the social world of the Pauline churches (for example, pointing out that Philippi was a Roman colony consisting of veterans). A quarter of a century later, Meeks' book has been critically revisited in After the First Urban Christians (2009), but a gap remains unfilled. Raymond Hobbs is right when he says: "Many studies of the Roman-Hellenistic social world of the New Testament offer a strange silence on things military."

Why are soldiers passed over? The answer flickers brightly through Meeks' comment that soldiers are a problem, especially a moral one. This is the way in which scholars usually discuss the military. Nearly all scholars focusing on soldiers in early Christianity basically consider them in a modern sense, not a historical one. More precisely, this motivation springs from the needs of modern Christian ethics, in which soldiers, wars and armies represent nothing but a problem. ${ }^{3}$ Such a viewpoint surely makes soldiers a less attractive theme for the more historically oriented scholar. The present situation of scholarly discussion makes me treat earlier studies with caution. In the words of David G. Hunter, soldiers and early Christianity are "a field where ideological bias seems so often to affect one's interpretation of the evidence."4 However, these studies are not worthless. As Roland Bainton puts it, the "various contentions are not to be dismissed simply because they support the views of those who propose them. Some may be right."

1 Meeks 1983, 20.

2 Hobbs 2001, 334; see also Zeichmann 2019, 42.

3 Helgeland $(1974,149 ; 1979,725)$ puts the scholars discussing soldiers into three categories: Roman Catholics, Protestant pacifists, and "establishment" Protestants, mainly Lutherans. The fact that the categorization is based on religious confessions illustrates the modern point of view.

4 Hunter 1992, 92.

5 Bainton 1986, 67 . 
To give an example, C. John Cadoux's The Early Christian Attitude to War: A Contribution to the History of Christian Ethics (first published in 1919) is a classic in its area, which contains rich source material of great value for anyone interested in the topic. The book surveys biblical and other early Christian texts, both pro- and antimilitary, and yet it has Christian pacifism as its underlying mission. ${ }^{6}$ Cadoux criticizes non-pacifistic readings of the sources, among others Adolf Harnack's Militia Christi: The Christian Religion and the Military in the First Three Centuries (German orig. 1905; English trans. 1981), which is also a classic. Cadoux thought that there was an original antimilitary ethos in early Christianity, which he traced back to Jesus. Interestingly, Harnack shared this view. ${ }^{7}$ Both scholars were unanimous that this original ethos was then gradually changed to a more positive attitude toward Christian participation in the army. Both avoid falling prey to the popular misconception that the existence of a Christian soldier would be a possibility only after the Constantinian turn in the fourth century. Unlike Harnack, Cadoux thought that the positive attitude was a minor trend even after the Constantinian turn. He criticized Harnack and other scholars for overestimating the approval given to Christian soldiers in the early Church. ${ }^{8}$

In the early Church Cadoux found what he needed to provide an arguable ethical judgment against any participation in bloodshed. ${ }^{9}$ However, he was no blinkered pacifist. He was also sensitive to the fact that there were Christian soldiers in the early Church and that they were more or less tolerated..$^{10}$ This fact does not destroy his pacifist argumentation, however, as he traces pacifism back to Jesus and shows witnesses from the early Church who understood Jesus' words in an antimilitaristic sense. Cadoux explains the participation of early Christians in the army as the result of a certain immaturity of reflection, noting that there was no exigent reason for such reflection: Christians could easily avoid enlistment in the army, if they liked. But the lack of reflection also made room for various compromises. Cadoux explains, "This, of itself, meant

$6 \quad$ Hunter 1992, 92. Gero (1970, 285 n. 1) speaks of Cadoux's "doctrinaire pacifism."

7 Harnack 1981, 65 .

8 Cadoux 1919, 254; McInnes Gracie 1981, 9-10. Recently, Despina Iosif (2013) has strongly questioned the pacifistic readings. She tends to read sources as approving of military service.

$9 \quad$ McInnes Gracie 1981, 9.

10 Shean $(2010,76)$ goes too far when claiming that "Cadoux refused to acknowledge any Christian participation in the military" and that "Cadoux's arguments represent the most extreme pacifist position and are the least convincing historically." 
that at any time after the inception of Christianity, the existence of Christian soldiers was at least a possibility."11

This seems to be a historical result as long as a reader forgets Cadoux's interest in the search for a norm for modern Christian ethics. He can admit early Christian participation in the army as long as he can find an authoritative pacifistic tradition originating in Jesus and looming large enough in the early Church. After the horrors of World War I, Cadoux found a modern function for the tradition he constructed. This, however, is not my interest. Reading his book, I prefer to place more emphasis on the historical side, asking a further question: if Christian soldiers possibly existed since "the inception of Christianity," as Cadoux admits, did any really exist? What can we say about them in historical terms? My aim is to make a shift from applied exegesis to a more historically oriented one.

The earliest indisputably documented Christian soldiers served in the late second century. ${ }^{12}$ The scholarly discussion on the participation of early Christians in the army deals mainly with sources from that time or later. This is mostly the case with the recent study Soldiering for God by John F. Shean, whose viewpoint is largely historical without any overt theological or ethical program. He engages in groundbreaking work at the crossroads of Christianity and the Roman army. However, the time before Marcus Aurelius' reign (late second century) only occupies a minor place in his learned study. Unfortunately, historically oriented research mainly moves from covering soldiers from earlier times to instead discuss what Jesus' words on love, nonresistance, and so on mean for Christian ethics today. Yet, even the earlier documents should undergo scrutiny from a historical standpoint.

In the historical approach, one should be open to differing views instead of searching for one, in particular only one, authoritative Christian stance; it is typical for many studies to pursue the Christian view on war and soldiers. As Shean rightly notes, early Christianity was not a unanimous movement. He continues:

This also means that there was no effective control over who could be a member of these different groups and that it is not possible to say with any assurance that soldiers could not be found among those calling

11 Cadoux 1919, 244-249. Similarly, Hays acknowledges that military figures were presented in a favorable light in the New Testament, but thinks it inconsistent with the overall message of the New Testament: "The place of the soldiers within the church can only be seen as anomalous" (Hays 2004, 335-337). Hays treats the subject openly from a modern ethical point of view. 
themselves Christians. Nor can it be said that all Christian groups would have had the same attitude towards the use of violence. ${ }^{13}$

The core of my interest does not lie in the general ethics of love and nonviolence, although I will take a short look at these in the Sermon on the Mount. There is a more direct road in our quest to discover early Christian soldiers: those passages where soldiers are mentioned. How true these passages are in terms of the historical record is another matter, however. Fortunately, the question of the historicity of the descriptions is not of primary importance. What is important is the fact that the descriptions surely bear the values of their Christian authors. ${ }^{14}$ If a soldier is described positively, or described even as a Christian, it certainly betrays something of the actual practice or at least the values of the author. One must be careful not to conclude too much based on scanty evidence, for the values that the portrayals express are not straightforward. In this sense there is a danger of interpreting the values anachronistically, if one does not realize that value judgments always represent opinions within a certain social situation. Focusing on the social situation brings us out of the abstract domain of values and grounds us in a more historically reliable context. Such a position helps to anticipate with greater accuracy the actual practices within early Christianity.

In 2014, two studies were published that have contributed to a greater understanding of the picture of soldiers in the New Testament: Laurie Brink's Soldiers in Luke-Acts: Engaging, Contradicting, and Transcending the Stereotypes and Alexander Kyrychenko's The Roman Army and the Expansion of the Gospel: The Role of the Centurion in Luke-Acts. Brink's and Kyrychenko's approaches are close to mine. They do not concentrate on what modern Christians should think about war and soldiers, but how Luke's description can be understood in its historical context. Brink and Kyrychenko scrutinize the picture of soldiers and the Roman army in the ancient sources so that the cultural background of Luke's portrayal becomes more apparent. Brink concludes that Luke piggybacks on the negative picture of soldiers in order to let Jesus exonerate them, like tax collectors and sinners. The soldier functions in Luke's treatment "as a parabolic exemplum of a good disciple, and as the author's optimistic expectation of imperial benevolence."15 Kyrychenko also sees that Luke-Acts gives a favorable portrayal of the Roman military, especially

\footnotetext{
13 Shean 2010, 9.

14 See Zeichmann 2019, 45: "Though some of these depictions are fantastical, they nevertheless elucidate how many civilians perceived soldiers of the Roman East."

15 See especially Brink 2014, 175 .
} 
centurions. Kyrychenko thinks that centurions represent the Empire in the narrative and that the positive picture of them proves that the Empire was a receptive mission field. ${ }^{16}$ Despite some differences between Brink's and Kyrychenko's analyses, ${ }^{17}$ their main conclusions amount to the same thing: Luke's soldiers exemplify the opportunity for a good relationship between Christians and the Empire.

Unfortunately, both studies focus only on Luke-Acts, which is just one among many early Christian sources. Moreover, I would question whether there is merely one portrayal of soldiers, even in a single ancient author's text. As I will argue, there are commonly two stereotypes in the ancient sources. The usual picture of centurions as different from the rank-and-file men is due to certain social factors. Thus, it is not enough to read just early Christian texts in the frames of the ancient stereotypes; it is also important to read behind the stereotypical representations and ask, what was the place of soldiers in the social reality of the Empire. This makes us conscious of why the stereotypes are what they are. Social reality also makes us see where and how early Christians factually encountered soldiers. In this way, we can take a step closer toward historical reality.

My thesis is that there were Christian soldiers from the very beginning of Christianity. This does not mean that all Christians accepted the military vocation. Some did, some did not, and some did not even consider the matter. There are three large aspects regarding this matter: (1) the dual view of soldiers in the gospels, (2) the use of military metaphors, and (3) the difference between the non-military views of the early Christian theologians and the actual reality in the ranks of Christians, which included soldiers.

First, I treat the dual view of soldiers in the gospels: centurions seem to be positive characters, while the rank-and-file soldiers are more ambiguous figures, mostly negative ones. The modern phrasing of the question on early Christianity and the military has left scholars to emphasize either the positive or the negative side, depending on their interests in either defending or resisting Christian participation in the military. However, because the duality of soldier characters in the gospels is actually there, the task is to explain it. I will put the gospels into their ancient social context, which shows that the duality was a common view among the ancient population. In order to properly frame the gospel material, I take a view on the presence of the military in the Eastern Mediterranean area in the first two centuries. Where did people encounter soldiers? How were the army and the rest of society interconnected? The answers

\footnotetext{
16 See especially Kyrychenko 2014, 189.

17 Kyrychenko $(2014,6)$ criticizes Brink for arguing that there was only one common set of stereotypes of soldiers "known and accepted by Luke and his intended audience."
} 
to these questions introduce us to the social context of the scattered sayings in the gospels and make visible the pattern of connections between soldiers and Christianity.

After looking at the gospels, I look at the military metaphors in the early Christian literature. Scholars have discussed whether these betray the existence of soldiers among the early Christians or not. I show that the use of military metaphors belongs to the longer philosophical tradition, which can be traced back at least to Plato. An analysis of Christian texts and how they compare with philosophical analogies leads mostly to negative results. Only in 1. Clement does the wording betray a positive identification with the Roman soldiers as "our soldiers." On the other hand, the vocabulary of Latin Christianity betrays a strong connection with the army. This is a question which I deal with on a deeper level when discussing Tertullian.

Turning from military metaphors to the theologians of the early Church, I compare their views to the other data we have on early Christians. I claim that most theologians, such as Justin Martyr, Irenaeus, and Clement of Alexandria, belonged to the philosophically minded intellectual class of the society. The intellectuals of the early Empire had rather reserved or even overtly negative attitudes toward the military. They could use military metaphors but usually without indicating any positive stance regarding the army or soldiers. The common Christians, however, lived their life in the larger social context, including the army. According to archeological evidence, the Christian soldiers seem to have had public piety as early as the beginning of the third century. This is in conflict with the reserved attitude of the Christian intellectual elite.

Interestingly, Tertullian brought the two strands together in the beginning of the third century. At the end of this chapter, I concentrate on him. Tertullian was passionately against Christian participation in the military, but when promoting his view he also openly states that there were many Christians in the Roman legions. The military influence on the North African Church seemed to have been strong, and it is indeed felt in the vocabulary of the Latin Bible translations and in Tertullian's own language. Tertullian's words prove the dual relationship to the military among the early Christians.

\section{Soldiers in the Gospels Contextualized}

1.1 The Army in Roman Society

1.1.1 Police Work

Cadoux wrote his book in a time when the trenches and bloody massacres of World War I were still fresh in memory. "The most crying and scandalous evil of our time," as he notes in the closing pages, aimed at large-scale warfare with 
mass destruction. When we turn that view toward ancient Rome, however, one sees that the imperial army had far more tasks than large-scale campaigns. ${ }^{18}$ The disasters of the Jewish War and the Bar Kokhba revolt do not tell the whole truth of the Roman army, its tasks, and its presence in the East. Actually, campaigning seems to be the exception. Roy W. Davies explains, "Many soldiers would have spent only a small part of their quarter of a century's service taking part in campaigns; there must have been quite a few who rarely, if ever, saw active service, as several writers noted about the troops in Syria and the East."19 This does not mean that soldiers spent their time peacefully. After an area was occupied, the army started to consolidate Roman control, which was often a violent process taking many years. ${ }^{20}$

In Judaea-unlike in Galilee-the local unrest was continuous. ${ }^{21}$ While it is a matter of definition how long the process of consolidation took there, it is clear that the army continued to be present even afterwards. The troops had a role in maintaining Roman control, overcoming local unrest, cooperating in judicial processes, executing punishments, and safeguarding tax collection or exacting taxes themselves. ${ }^{22}$ Davies notes that the New Testament provides a catalog of the various police jobs routinely performed by soldiers:

They arrested and flogged Christ; an execution squad of a centurion and four armed soldiers crucified Him and two brigands, detained earlier in a security operation, but not Barabbas, in custody for insurrection and murder; a small picket guarded the tomb; the rest of the cohort was drawn up in full battle kit in the governor's residence, ready to suppress any outbreaks of rioting. In Jerusalem the men of the cohors equitata commanded by Claudius Lysias had to rescue Paul from a lynch mob three times in twenty-four hours; he was arrested, almost flogged, released, taken into protective custody, and then sent under heavy armed escort to Caesarea for trial. The tribune wrote an official report and came to give evidence. In the capital he was first held in custody in the governor's residence, but was then put under open arrest under the surveillance of a centurion for two years. When the governor left, Paul was put back into protective custody, appealed to his successor, and was remanded in custody pending transport. On the sea voyage he was under open arrest,

\footnotetext{
18 Isaac 2000, 54 .

19 Davies 1989, 33 .

20 Isaac 200o, 54-67; Campbell 2002, 9o.

21 Isaac 20oo, 77-89. On Galilee, see Freyne 1998, 245-246.

22 Davies 1989, 56-57; Isaac 200o, 113; Campbell 2002, 9o; Kyrychenko 2014, 29-32.
} 
but the non-Roman prisoners were kept under close arrest by the centurion and escorts of cohors I Augusta; in Rome the latter were confined in the camp of the Praetorians by the princeps peregrinorum [the head of the castra peregrina, the headquarters of the secret police in Rome; peregrini were people without Roman citizenship], while Paul was kept under house arrest with one soldier for two years. ${ }^{23}$

Davies mentions in passing that secret police also appear to have been present in Rome, as Epictetus describes:

In this fashion the rash are ensnared by the soldiers in Rome. A soldier, dressed like a civilian, sits down by your side, and begins to speak ill of Caesar, and then you too, just as though you had received from him some guarantee of good faith in the fact that he began the abuse, tell likewise everything you think, and the next thing is-you are led off to prison in chains.

Epictetus, Disc. 4.13.5; trans. Oldfather, LCL

Epictetus is obviously describing the politically heated atmosphere of the capital city, not his immediate environment in Nicopolis in Greece. ${ }^{24}$ However, it tells how far soldiers' tasks could be from battlefield operations. It is also worth noting that soldiers are described as informers in the Gospel of Luke, where

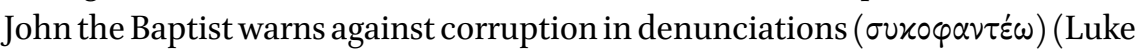
3:14). This warning fits well with the general picture of soldiers as policemen.

On the other hand, the army was not alone in policing. Christopher J. Fuhrmann points out in his Policing the Roman Empire that there were also other organizations safeguarding the order. The civil policing institutions were most developed in Egypt and in Asia Minor. In the Martyrium of Polycarp,

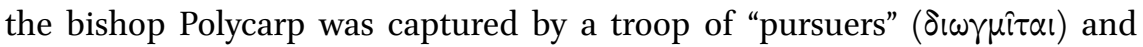
horsemen (Mart. Pol. 6.2-7.1), whose leader is called an "officer of the peace" (Eipท́vapXos). These Greek words denoted particular city officials. ${ }^{25}$ Yet, Fuhrmann also shows how the army took an increasing role in policing during the first three centuries CE. ${ }^{26} \mathrm{He}$ even sees this trend in the gospels: in the earliest ones, Jesus is arrested by armed rabble, but John writes of a military unit.

23 Davies 1989, 57.

24 Fuhrmann $(2012,143)$ notes that this is the only case when soldiers were used as agents provocateurs. Yet, the civil disguise is attested to by other sources (Fuhrmann 2012, 115).

25 Fuhrmann 2012, 66-69.

26 Fuhrmann 2012, 6-12, 93, 202. 
Fuhrmann points out that when Origen was commenting on Matthew, he did not understand the scene without soldiers and referred to John. ${ }^{27}$ By the third century, a reader of the gospel could not imagine an arrest without soldiers.

Police work, or any other paramilitary or nonmilitary tasks ${ }^{28}$ carried out by the army, did not change the fact that soldiers were, first and foremost, fighters. They regularly conducted exercises for warfare, ${ }^{29}$ but their daily drills are not described in the earliest Christian sources. There are references to military campaigns in the Jewish War (e.g., Luke 19:43-44), but Davies' words above are revealing: the New Testament primarily describes their police work, although that differs from the modern understanding. Another difference is the decentralized form of military command. In modern Western societies, usually the army is strictly under the command of the government. This was not the case in the Roman Empire. The vassal rulers had their own armies. Thus, for example, Herodian client rulers had their own military forces, as Josephus informs us. It was exceptional for Roman troops to be present in the areas of the vassal rulers. ${ }^{30}$ Moreover, the Roman army did not only consist of regular troops, but also auxiliary units, mostly made up of locally recruited manpower and possibly even Italian citizens, like Acts 10 reports. ${ }^{31}$

It is clear that soldiers and Christians did not encounter one another only in times of war, but in many other ways in everyday society. In his study Soldiers, Cities, and Civilians in Roman Syria, Nigel Pollard uses two scholarly models to show the relationship between the Roman army and the local population. The older model emphasizes the integration of the army and the rest of society, while the more recent one reconstructs their relative separation. ${ }^{32}$ Pollard himself remains halfway between these, arguing that there were elements of both separation and integration. The Romanization of soldiers-without any word of the surrounding society - was superficial. However, the army as an institution created a separate social identity. ${ }^{33}$ I will first look at the separation, which was manifested in the tensions between the army and the local people. After that I will address the integrative element visible in the positive relationships between the army and the civilians.

\footnotetext{
27 Fuhrmann 2012, 240.

28 "Soldiers were dispatched as surveyors, engineers, even judges. They built roads, supervised mines, and collected supplies" (Fuhrmann 2012, 105).

29 Davies 1989, 41-43.

30 Chancey 2007, 54. Kyrychenko (2014, 35 n. 141) lists some exceptional cases.

31 Chancey 2007, 49. I will later note that despite the name of the unit, manpower could also be recruited in the provinces.

32 Pollard 2000, $5^{-7}$.

33 Pollard 2000, 7-8.
} 


\subsubsection{Tensions between the Army and the Local People}

Roman police work was not so much aimed at protecting people than at attending to the interests of the Empire. ${ }^{34}$ The bigger detachments were usually concentrated in camps in the countryside, except in the East. There were big garrisons in Antioch, Caesarea, Jerusalem, and Alexandria. Benjamin Isaac assumes that the reason for the exceptional practice in the East was the need for tighter control over the local centers. ${ }^{35}$ From the beginning of the second century, there is increasing evidence of soldiers being widespread in outposts in both small towns and the countryside. ${ }^{36}$ One of the main purposes of these outposts was maintenance of Roman order. ${ }^{37}$ All this suggests some kind of tension between the army and the local people. This tension is clearly felt in Paul's words on earthly authorities in Romans 13. He is uncompromisingly loyal to the authorities, but his line of thought is interesting. Besides the theological reasoning — which scholars have always noted - he also provides a more "secular" interpretation: you must ( $\alpha \dot{\alpha} \gamma \gamma \chi \eta)$ obey in order to avoid wrath (Rom. 13:5). He speaks of the fear before authority, which bears a sword and executes wrath (Rom. 13:3-4). The fear that Paul describes is an emotional echo for a population that understands how the troops will overpower any resistance or unrest. ${ }^{38}$

One source of tension between soldiers and the local population was the practice of requisition. Its technical term in Greek was angareia (årapsi $\alpha$,

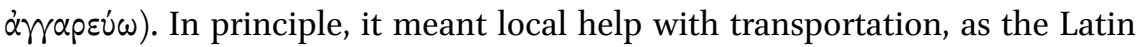
cognate vehiculatio expresses. Jonathan P. Roth explains, "Both animals and drivers, including slaves, freedmen and free persons were requisitioned for such duty. The Roman army also routinely requisitioned civilians to carry supplies." ${ }^{39}$ Demanding angareia was allowed for state officials. Soldiers could practice it only with an official permit, but in reality this limitation was just theoretical. Soldiers often exercised requisition without any permit. They could confiscate clothes, foodstuff for men and animals, firewood - practically anything. Angareia also made it possible to commission local people or their animals. The latter could be returned or not. ${ }^{40}$ Fuhrmann notes that "the very

\footnotetext{
34 Campbell 2002, 88; Fuhrmann 2012, 8, 91, 119.

35 Isaac 2000, 269-282.

36 Fuhrmann 2012, 10.

37 Davies 1989, $5^{6-57}$.

38 Hobbs 2001, 334-335.

39 Roth 1999, 110.

40 Rostovtzeff 1971, 381-388; Wink 1988, 215-218; Davies 1989, 51; Isaac 200o, 282-297. A picture of angareia is presented in a funeral stele (Rostovtzeff, plate LXXIV). Angareia or vehiculatio was officially different from annona (grain provisions) and taxation.
} 
expansion of military policing increased soldiers' abuse of civilians, evident in several sources." Emperors tried to limit the malpractice in vain. ${ }^{41}$

The work compelled of the people is exemplified by Simon of Cyrene, whom the soldiers forced ( $\alpha \gamma \gamma \alpha \rho \varepsilon v$ ovov) to carry Jesus' cross (Mark 15:21; cf. Matt. 27:32). In the Sermon on the Mount, not only did Jesus exhort his followers not to resist angareia, but to do even more than was required (Matt. 5:41). The alternative that Jesus rejects is a scuffle (i.e., "if anyone strikes you ..." in Matt. 5:39). Angareia is described in a lively manner by Apuleius in Metamorphoses. The main character of this comic novel is Lucius, who is transformed from a man into a donkey and tells about his adventures. Once, being in the possession of a gardener, he met with a soldier who was clearly doing what I call angareia. ${ }^{42}$ The soldier says to the gardener that he needed the donkey. He took it by the halter and would have taken it away if the gardener had not started to beg and finally fight. The soldier was overcome, and to avoid further battery he feigned death. The gardener fled and hid himself with the donkey (Apuleius, Metam. 9.39-40). Overcoming a soldier may have been an exceptional case, of course. Juvenal reports the advantages of being a soldier as follows.

First, let's deal with the advantages shared by all soldiers. Not the least of these is that no civilian will have the nerve to beat you up. Instead, if he gets beaten up himself, he'll pretend he wasn't, and he won't be eager to show the praetor his teeth that have been knocked out, or the black lump on his face with the swollen bruises, or the eye he still has, though the doctor isn't making any promises.

Juvenal, Sat. 16.7-12; trans. BROUND, LCL

Epictetus shares general wisdom about the right attitude to express when a soldier might require a donkey: "If it be commandeered ( $\alpha \nu \delta$ ' $\alpha \gamma \alpha$ p a soldier lay hold of it, let it go, do not resist nor grumble. If you do, you will get a beating and lose your little donkey just the same" (Disc. 4.1.79; trans. Oldfather, LCL). Roth claims that Epictetus' advice "was sound common sense for provincials wishing to avoid bodily injury."43 Interestingly, Didache 1.4 seems to share Epictetus' pessimism. The passage roughly follows Matthew 5:38-41 with its reference to angareia. There are small differences, however; of

41 Fuhrmann 2012, 11, 159-161. See Pollard 200o, 85; Fuhrmann 2012, 133-134, 232-237.

42 There is no technical term for angareia in the story, either in the Latin or in the Greek version of it (Ps.-Lucian, Asin. 44-45). One may also note that before entering Jerusalem in a kingly fashion, even Jesus seems to have practiced something like angareia, commanding disciples to take a donkey and a colt with a promise of their return (Matt. 21:2-3) (see Derrett 1971, 243-249).

Roth 1999, 145. 
these, the concluding words catch the eye: "If anyone seizes what is yours, do

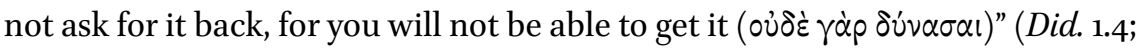
Trans. Ehrman, LCL). The author seemingly thinks it an impossibility to resist angareia. ${ }^{44}$ Even in Apuleius' story the soldier finally gets the donkey after a home search, which is based on a false denunciation by the soldier and his comrades. Later the soldier sells the donkey for eleven denarii (Metam. 9.4142; 10.1, 13). In Apuleius' story, angareia became robbery. Similar malpractices are reported frequently in the Roman sources. ${ }^{45}$

The reason for such robbery was not always pure greed. A soldier's pay was not generous, being little more than the wages of a laborer. We have information of corrupt officers who kept the pay of their men ${ }^{46}$ while pay was deducted for necessities organized by the troops. Furthermore, the pay of auxiliary troops was less than that of the regular army. ${ }^{47}$ So, what Sirach complained about some centuries earlier could indeed have been true: "a warrior in want through poverty." Interestingly enough, Sirach did not view soldiers with contempt, comparing the poor soldier with "intelligent men who are treated contemptuously" (Sir 26:28). Percennius, a rebellious soldier under Emperor Tiberius, also provides an impression of the difficulties a soldier could encounter. According to Tacitus, he lamented the following iniquities:

In fact, the whole trade of war was comfortless and profitless: ten asses a day was the assessment of body and soul: with that they had to buy clothes, weapons and tents, bribe the bullying centurion and purchase a respite from the duty.

Tacitus, Ann. 1.17; trans. JACKSON, LCL ${ }^{48}$

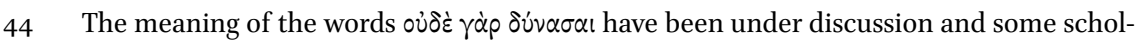
ars prefer textual emendation. Niederwimmer $(1998,79)$, however, considers the meaning to be obvious: "Let yourself be robbed, because you cannot really defend yourself, no matter what!" I would like to add that the robbery may be angareia — at least if we look at the textual context, which explicitly speaks of angareia.

45 Campbell 2002, 91-92. Zeichmann (2019, 47) also notes these practices, although he strangely misunderstands what Paul says in 1 Cor. 9:7: "Who at any time pays the expenses

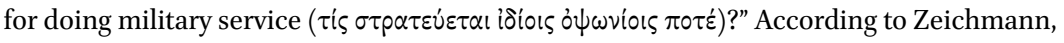
Paul suggests that soldiers do not spend money earned in their service ( $\dot{\psi} \psi \omega \dot{\omega} v 1 \alpha)$. Yet, as the parallel examples in the same verse (planting a vineyard and tending a flock) show, Paul must have thought that soldiers used the money earned in their service for their subsistence. Indeed, this was the normal practice in the army. What Paul denies is that the soldiers should cover their subsistence by any "own money" received outside of their service.

46 Isaac 200o, 273; Williams 1999, 244 n. 156.

47 Pollard 2000, 179-182.

48 The rates of the payment varied considerably during the course of the empire, depending on costs and circumstances. See, e.g., MacMullen 1963, 155-156; Campbell 2002, 83-89. 
Tacitus describes how respite from duty laid an economic burden on the shoulders of the rank and file. No one cared how the soldiers got their money. Tacitus continues: "In reality, it was through highway robbery, petty thieving, and by menial occupations that the soldiers purchased rest from military service" (Tacitus, Hist. 1.46; trans. Moore, LCL). ${ }^{49}$

These miseries were just one side of the coin. There were also advantages to be had in the Roman army, which drew one to enlist. No laborer could dream of a contract for 25 years, complete with medical care, a pension, and Roman citizenship. ${ }^{50}$ The prevalence of voluntary recruitment surely attests to the fact that the average soldier was content with his occupation, ${ }^{51}$ and the opportunities for some extra income via private angareia probably helped with this contentment. But it was for this very reason that a soldier encountered tensions with the local population of the area.

\subsubsection{Positive Relationships between Soldiers and Civilians}

The tension between soldiers and local people is only one part of the picture. At the same time, one has to recognize that the army recruited soldiers from around a vast empire, and these recruits were not necessarily brought from their original home area. ${ }^{52}$ In such cases, the tensions with local people were lighter. Another factor that lessened tension was marriages made with local women (see, e.g., Tacitus, Hist. 2.80). Until Septimius Severus, who reigned in 193-211, Roman soldiers were forbidden by law from contracting a marriage; in practice, however, concubinage was common and widely tolerated. The ban on marriage caused perpetual problems, since the status of a soldier's child was that of a bastard, making it impossible to be an heir of the father. For soldiers, the unofficial status of family ties was hard to accept and there were attempts to reduce the obstacles caused by the ban on marriage. For instance, families settled close to the garrisons. ${ }^{53}$

Among the auxiliary troops, marital unions were acknowledged. After twenty-five years of service, an auxiliary and his family received Roman citizenship, ${ }^{54}$ and centurions of the auxiliary troops were often citizens already during their service. The soldiers of vassal rulers were also free from the marriage ban. For example, Herod's soldiers could have families. I will later discuss

\footnotetext{
49 Sometimes soldiers simply changed career from the military to robbery (Kloppenborg 2009, 469-471).

$50 \quad$ Campbell 2002, 34 .

$51 \quad$ Davies 1989, 68.

$5^{2} \quad$ Pollard 2000, 115, 132, 133; Campbell 2002, 25-32.

53 Campbell 1978, 153-159; Campbell 2002, 96-97; Kyrychenko 2014, 168-170.

54 Saddington 1996, 2411.
} 
the case of the centurion in Capernaum, which was under Herod's rule, but I note here that according to Matthew (8:6) he had a son (as we should translate the word $\pi \alpha \hat{\imath}) .{ }^{55}$ Moreover, Fuhrmann supposes that soldiers who were detached from their legions and given posts among civilians created more or less lasting relationships with local women. This is the social background of Celsus' claim that Jesus was a son of a soldier called Panthera. ${ }^{56}$

Though one should not exaggerate the economic effects of the army, its presence surely stimulated trade..$^{57}$ Supplying the army did not happen only through requisition, but also via the open market. If soldiers had wealth, they could take part in business, contract debts, or lend money. A document from the Judean desert dated $124 \mathrm{CE}$ reveals that a centurion in the camp of En Gedi lent money to a Jewish owner of a local palm grove, ${ }^{58}$ thus showing the economic resources of centurions. In the early first century $\mathrm{CE}$, centurions earned about fifteen times the salary of a legionary. This does not mean, however, that centurions were from wealthy families. While the rank and file came from low social backgrounds, the centurionate was socially heterogeneous. Centurions were in the main the most experienced soldiers in the army, and they were often destined to rise to more senior posts and then into the civil administration. ${ }^{59}$ Service in the army was a way of climbing the social ladder.

Local communities could honor centurions as benefactors in inscriptions. For example, the people in the Syrian village of Phaena thus distinguished a centurion as "friend and benefactor." ${ }^{60}$ Sometimes centurions acted as judges. ${ }^{61}$ Centurions were often asked for help in situations that were officially not their tasks, ${ }^{62}$ and Richard Alston has illustratively described the confidence which local people could feel toward them. Soldiers could act on behalf of locals in legal cases or present petitions to the emperor, representing the population. In addition to the official cult, they could also worship diverse deities, including local ones. ${ }^{63} \mathrm{John}$ F. Shean writes on the cult of local deities:

55 Luz 2001, $10 \mathrm{n} .17$; cf. John 4:46. Saddington (2006) shows that the meaning of "boy love" is anything but evident. Later I will address the historicity of the story.

56 Fuhrmann 2012, 229-230.

57 MacMullen 1963, 90-95; Pollard 200o, 182-191; Campbell 2002, 92-96.

58 Campbell 2002, 100. For a close reading of the document, see Oudshoorn 2007, 156-168.

59 Wegner 1985, 61-63; Campbell 2002, 32-33, 41, 103; Fuhrmann 2012, 242.

6o Pollard 2000, 88.

61 Pollard 2000, 94.

62 Alston 1995, 86-96. The evidence is from Egypt. See also Kyrychenko 2014, 86-89.

63 Helgeland, Daly, and Burns 1981, 48; Campbell 2002, 100. 
In the course of moving from one area of the empire to another, a soldier was conscious of the fact that he could encounter and unwittingly offend various local spirits who were unknown to him but, nevertheless, could potentially harm him out of pique. To ensure peace-of-mind, soldiers recently arrived at a new, alien post would set-up altars to the genius loci ('spirit of the locality'), a generic term used by Romans for any unknown spirits in a given area, however, those spirits already known by name would be directly addressed. ${ }^{64}$

One should not overestimate, however, the attraction of the local deities among the soldiers. Pollard's analysis of the archeological evidence shows only limited partaking by soldiers in the local cults. ${ }^{65}$ Of these, there are some dedications to local deities. For example, a former centurion of Moesian extraction offered to the Phoenician god Baetocaece. ${ }^{66}$ Shean points out that centurions belonged to the itinerant officer corps; often changing posts actively, they became acquainted with numerous deities and were the most open to new ones. ${ }^{67}$ In this context, the picture of the centurion who had funded a synagogue in Capernaum is credible (Luke 7:4), as is Cornelius the centurion, called a God-fearer (Acts 10:2); of course, this does not prove the historicity of these accounts. ${ }^{68}$ There were also Jewish soldiers in the imperial army. ${ }^{69}$ From this economic and religious background, Shean concludes:

From the point of view of the church soldiers, especially officers, would have been too attractive from a sociological perspective to reject out of hand considering the important role of the Roman military in imperial society. Roman army officers were a positive asset due to their leadership skills and their financial resources. They also would have been amenable to taking up the faith given their proclivity to be religious innovators. ${ }^{70}$

In sum, soldiers in the world of the early Christians were doing something that today is called police work. Because the army attended more to the interests of the Empire than to the population, the latter could feel the army as a

\footnotetext{
64 Shean 2010, 39.

65 Pollard (2000, 142-149) points out that there were three dimensions in the religiosity of the soldiers: state cults, unofficial military cults (like that of Mithra), and local cults.

66 Pollard 2000, 148.

67 Shean 2010, 41.

68 See Shean 2010, 139-140.

69 Schoenfeld 2006.

70 Shean 2010, 141.
} 
threat. At the same time, there were also traces of more positive interaction. This twofold experience of soldiers comprises the context of that described by the early Christian sources (all early Christian authors seem to have been civilians). These give voice to encounters with soldiers which were both positive and negative. The accounts do not necessarily include any principled comments on pacifism, conscientious objection, military service, just war, or other moral matters that interest many modern scholars. The accounts mirror more the civil experience of soldiers in their everyday life. The image of centurions presented in the ancient sources is quite often better than that of the rankand-file men. Although there are exceptions to this general rule, I claim that this division is decisive for our understanding of the attitudes toward soldiers in the gospels. ${ }^{71}$

While I do not mean to deny that the sources can also include more principled views, one should be careful not to search too hard for a moral statement in any verse referring to soldiers. The sources are primarily an echo of the diverse social experience. What Mark says about soldiers is partly colorless, partly negative, and partly positive. One cannot find traces of any principled view, for instance. Matthew strengthens the ambiguity between good and bad soldiers, but the value judgments do not seem to mirror any judgment on having a military calling as such, though scholars usually tend to think so. Luke whitewashes the dark side of the soldiers. Compared with Matthew, Luke has a more positive picture, which becomes even clearer in Acts. Regarding John, his comments on soldiers are limited to the Passion narrative, not appearing elsewhere. Among the gospels, John seems to have the most negative attitude toward soldiers. The Gospel of Peter offers an interesting development of the gospel tradition; in a story that is parallel to that in Matthew, soldiers are mentioned at the tomb. It is noteworthy that Matthew paints a very negative

71 See Fuhrmann 2012, 231. Brink $(2014,139)$ claims that the picture of centurions was less favorable than I claim. First, her examples from Tacitus speak of the relationship between centurions and the rank and files. I have cited a similar example above. My aim is to speak of the relationship between centurions and civilians. Second, Brink refers to Juvenal's Satires 16, which I also cited above. This text speaks of the bullying rank and file defended by a centurion judge. The centurion is just a side figure, but he admittedly acts against the civilian. Certainly centurions also acted negatively, but it is less frequently noted than Brink claims. Actually, Brink (2014, 74-77) herself notes that centurions also had quite a good reputation and refers, for example, to Alston's study, which I have also cited. Third, a negative picture of centurions reflects an upper-class and intellectual view, because the literary sources come mostly from that background (see Zeichmann 2019, 44). I will show later that early Christian theologians belonged to that social group, for whom military issues were quite unattractive. 
picture of the soldiers in this story, but the Gospel of Peter changes them into positive figures.

\section{$1.2 \quad$ Soldiers in the Gospels}

\subsubsection{Military Characters in Mark}

Mark mentions soldiers in four passages. Two of them are unique, as soldiers are not mentioned in the parallel stories of the other gospels. The first is the story of the death of John the Baptist (Mark 6:21-29), which is retold by Matthew (14:6-12) and briefly noted by Luke (9:9) without mentioning soldiers. Mark mentions soldiers twice, initially the ranking officers ( $\chi \imath \lambda i \alpha p \times \circ)$ among the guests and then the speculator $(\sigma \pi \varepsilon \kappa 00 \lambda \dot{\alpha} \tau \omega \rho)$, who beheads John in the prison. The latter term is a Latin loanword in Mark, which can mean a scout,

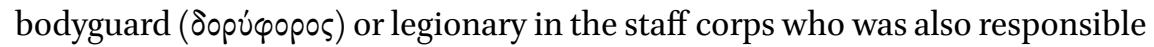
for executions. ${ }^{72}$ These soldiers in Mark's story are just extra characters. The officers included among the other exalted guests in Herod's banquet are just there to add color to the high society around the tetrarch. ${ }^{73}$ The speculator carries out Herod's command. Neither Matthew nor Luke mentions these extra characters, about whom Mark has nothing more to say. Yet, we must note that although these soldiers are quite colorless, from the evangelist's point of view they belong to a remote environment, that is, to Herod's court. Mark seems to have no closer relationship with the soldiers.

This is also the impression given by the synoptic apocalypse. It does not even mention soldiers, though it speaks of wars. Wars are the basic elements of an apocalyptic vision of the future: "When you hear of wars and rumours of wars, do not be alarmed; this must take place, but the end is still to come. For nation will rise against nation, and kingdom against kingdom" (Mark 13:7-8). Nevertheless, the outbreak of wars is far beyond the power of Christians, and the wars are encountered with simple perseverance as are all the other eschatological sufferings: "But the one who endures to the end will be saved" (Mark 13:13). In this vast apocalyptic vision, soldiers as persons disappear from sight: wars like earthquakes and famines are powers independent of human agency. In the story of the death of John the Baptist, soldiers are just tools in Herod's hand. It is a question of Herod's and his wife's agency, not that of the soldiers. Therefore, Matthew could easily leave soldiers out of his version.

72 Liddell, Scott, and Jones 2011, $\sigma \pi \varepsilon \kappa 00 \lambda \dot{\alpha} \tau \omega \rho$; Lewis and Short 1969, speculator; Saddington 1996, 2413; Fuhrmann 2012, 193; Kyrychenko 2014, 32.

73 Verbally $\chi$ i $\lambda$ i $\alpha p X 0 เ$ are leaders of 1000 men. "It may not mean more than 'senior officer' in this context" (Saddington 1996, 2413). 
Raymond Hobbs, who has studied the soldiers in the gospels from a socialscientific point of view, thinks that Mark mirrors the threat felt by the rural people vis-à-vis the urban environment and its soldiers. Hobbs adds that the strategies for dealing with this threat vary from outright rebellion to apathetic non-involvement. ${ }^{74}$ If one follows Hobbs' distinction of the strategies, one must conclude that a colorless or non-existent depiction of soldiers expresses the apathetic strategy. However, the gospel does not primarily mirror the Palestinian rural viewpoint-as Hobbs seems to think—but Mark's own (urban?) environment. ${ }^{75}$ The story of John the Baptist's death presents Herod as a slightly sympathetic figure, who vaguely believes in John's message but is compelled to follow the will of his capricious wife. Thus, one cannot depict Mark's story as a black-and-white opposition between urban nobility and rural peasants. The story of John's death is more of a glance into the exotic but somewhat dangerous feasts of high society. Ranking officers and bodyguards belonged to this environment, which was remote from the author and his readers.

Besides the soldiers at Herod's feast, there are two other soldiers mentioned in Mark. In the Passion narrative, he depicts soldiers twice. First, there are the soldiers who mock Jesus (Mark 15:16-20), take him to Golgotha (15:20-22), and then crucify him and two robbers (15:23-27). Mark clearly describes the soldiers in a brutal light. After Jesus' death, a centurion makes a Christian-sounding confession: "Truly this man was God's Son!" (15:39.) A little later, the centurion corroborates to Pilate that Jesus is really dead (15:44-45). The reader may see an inconsistency between the behavior of the rank-and-file men and the confessing centurion. How could Mark describe soldiers in such a different light so close to each other? Or to ancient eyes was there any clear difference between them? Hobbs reminds us not to read our modern values into the story and criticizes the imposition of hasty moral judgments on the mocking soldiers:

They were, states Hagner, "rough men" and "immature" (Hagner 2.829832). Similarly Lane (Lane 559) characterizes this whole episode as an "impious masquerade," reflecting a "perverted sense of humor" on the part of the soldiers. The presuppositions of these judgments are, of course, modern and western. Such roughness and "immaturity" is expected of soldiers, and quite common in their acknowledged roles in first century politics (see Tacitus, Histories). Soldiers in all societies are trained to do

74 Hobbs 2001, 346.

75 Brown (1997, 161-163) discusses the place where the gospel is written. Although he leaves the location open, he is quite sure that it is not Galilee. 
harm to others, and nowhere was this clearer than in the Roman army (Watson 1969). It should come as no surprise then that soldiers inflict harm in the story of the crucifixion. ${ }^{76}$

Hobbs' evaluation bears some truth: one should expect nothing but this procedure from soldiers. They behaved just as soldiers are supposed to behave. Mark describes soldiers in a way that is familiar from other ancient sources: rank-and-file men are brutal. Thus, a modern evaluation of the mocking soldiers is not as wrong as Hobbs maintains. Though the ancient people expected brutality, it is not to say that this brutality was seen as being morally neutral. The Passion narrative surely expresses that Jesus experienced something negative. Robert M. Fowler claims that the vivid portrayal of their ironic mockery of Jesus is important for our understanding of the confession of the centurion. Fowler concludes that in light of the soldiers' irony, the confession is also easy to see as an ironic one: "the centurion utters the last of all the mockery committed by the soldiers and the passersby." Noting that the centurion sees the death of Jesus and the curtain of the temple being torn in two, Fowler asks rhetorically: "Why should we be surprised if he mocks the demise of both with cruel, insincere flattery?"77

Fowler's conclusion rests on the supposition that the centurion shares the brutality of the rank-and-file men. This presupposition can be questioned on the basis of the ancient point of view, however. As the picture of centurions was much more positive than that of the rank-and-file men, one should not be surprised by the different attitudes. Actually, it is noteworthy that Mark seems to differentiate the centurion from the rank-and-file men in his narrative. As Fowler says, the centurion is probably thought to be in charge of the execution squad, ${ }^{78}$ but he is not visible when the rank-and-file men mock Jesus, bring him to Golgotha, and put him on the cross. It is as if the rank-and-file men execute Jesus without supervision. They do the dirty work, while the centurion enters into the story to utter the Christological confession. Contrary to Fowler's supposition that the centurion is as brutal as the rank-and-file men, the ancient reader would have expected more civilized behavior from the officer. This is also what Mark seems to tell us. Fowler points out that the readers have "almost universally" understood the confession of the centurion as "the grand denouement in the Gospel."79

$\begin{array}{ll}76 & \text { Hobbs 2001, 333. } \\ 77 & \text { Fowler 1991, 207. } \\ 78 & \text { Fowler 1991, 203. } \\ 79 & \text { Fowler 1991, 204. }\end{array}$ 
I have here described what kind of characters the soldiers are in the Gospel of Mark. It does not, however, directly inform about any Christian soldiers in Mark's Christian community. What Mark tells of the rank-and-file men makes it improbable that there were any such soldiers in his Christian circle. If there were, they surely were centurions. At least Mark regarded it as credible that a centurion might confess Christ as the Son of God.

\subsubsection{Ambiguous Matthew}

Many readers of the Bible have seen a kernel of early Christian pacifism in the Sermon on the Mount. Even the word 'pacifist' is derived from the Latin translation of beati pacifici (Matt 5:9). If Matthew actually means an adherent of pacifism, it would be a strong value judgment, making it improbable that there were soldiers among the Matthean Christians. However, the beatitude on socalled pacifists does not make explicit what kind of peacemaking was at stake.

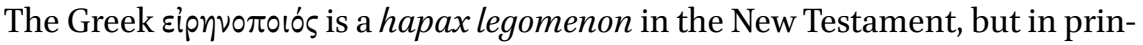
ciple it can bear overtones of making peace during war or maintaining peace in contrast to war (Xenophon, Hell. 6.3.4; Plutarch, Nic. 11.3), though not necessarily (Prov 10:10 LXX). The title was sometimes used of emperors. Cassius Dio claims that among the several superb titles that Commodus assumed, one was

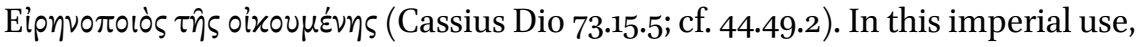

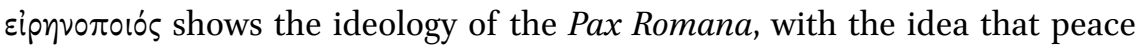
was brought by the Roman army. ${ }^{80}$ The character of this kind of peacemaking is famously described by the British Calgacus, who criticized Roman peace by means of the sword: "they make a desolation and they call it peace" (Tacitus, Agricola 30.5; trans. Hutton and Peterson, LCL). In the Jewish-Christian usage, the word 'peace' had a far broader meaning than the mere absence of war. ${ }^{81}$ This also makes peacemaking a broader concept. In Colossians and Ephesians peacemaking refers to Christ unifying Jews and gentiles (Col 1:20; Eph 2:15). For James, peacemaking means shunning quarrels in social relationships, but there is also the certain metaphorical weight of warfare.

A harvest of righteousness is sown in peace for those who make peace

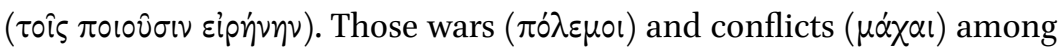

\footnotetext{
8o Swartley 1996, 2311-2314.

81 Swartley (1996) shows this in his article. He also demonstrates that similar ideas were present in the ideology of the Pax Romana: "Clearly the Pax Romana was celebrated as an ideal state of affairs, a time of one worldwide Greco-Roman language and culture, a time of prosperity and order. These latter features accord with the Hebrew notion of shalom." Swartley continues that the situations where the subjugated peoples suffered oppression "oppose and mock shalom" (Swartley 1996, 2312).
} 
you, where do they come from? Do they not come from your cravings that are at war $(\tau \hat{\omega} \nu \sigma \tau \rho \alpha \tau \varepsilon v \sigma \mu \varepsilon \dot{\varepsilon} \omega \nu)$ within your members? You want something and do not have it; so you commit murder. And you covet something and cannot obtain it; so you engage in conflicts and wars $(\mu \alpha \dot{\alpha} \chi \varepsilon \sigma \theta \varepsilon$ xai $\pi 0 \lambda \varepsilon \mu \varepsilon i \tau \varepsilon)$.

Jas 3:18-4:2

James, Plutarch, and Xenophon attest that the wording of Matt 5:4 may refer to the idea of making peace during war. Conversely, Prov 10:10, Colossians, and Ephesians attest to such an idea being anything but tenable. Everything depends on the textual context, where many have found a clear reference to pacifism, namely in the fifth and the sixth antitheses:

You have heard that it was said, "An eye for an eye and a tooth for a tooth." But I say to you, Do not resist an evildoer. But if anyone strikes you on the right cheek, turn the other also; and if anyone wants to sue you and take your coat, give your cloak as well; and if anyone forces you to go one mile, go also the second mile. Give to everyone who begs from you, and do not refuse anyone who wants to borrow from you.

You have heard that it was said, "You shall love your neighbour and hate your enemy." But I say to you, Love your enemies and pray for those who persecute you, so that you may be children of your Father in heaven; for he makes his sun rise on the evil and on the good, and sends rain on the righteous and on the unrighteous. For if you love those who love you, what reward do you have? Do not even the tax collectors do the same? And if you greet only your brothers and sisters, what more are you doing than others? Do not even the Gentiles do the same? Be perfect, therefore, as your heavenly Father is perfect.

Matt 5:38-48

On such words, Michel Desjardins comments: "The message found in these antitheses, if carried out, would make it virtually impossible for Christians to support war or to participate in most forms of violence, however broadly defined. This cannot be said strongly enough." ${ }^{\prime 2}$ Desjardins is not alone in this opinion, ${ }^{83}$ and this is obviously why he dares to state his view without any further grounds. Gerd Theissen is more sensitive to the social context presented

82 Desjardins 1997, 42.

83 See, e.g., Cadbury 1918, 86-88; Cadoux 1919, 22-25; Harnack 1981, 66; Luz 1989 with further references. 
here, which he traces back to the historical Jesus. According to him, the enemy that Matthew speaks of is a national enemy. Matthew perceived in Jesus' words an injunction against resistance in the manner of King Agrippa's speech in Josephus (Bell. 2.350-352). The words expressed a means to get through the bitter time after the defeated Jewish uprising. ${ }^{84}$

Theissen is right in claiming that Matthew understood Jesus' words as a way to get by. However, I would like to question his claim that they are closely connected to the post-war era. The references to a lawsuit and to lending imply that Matthew is speaking of normal peace-time activities. The reference to angareia presumes an encounter with a soldier, but even this does not indicate warfare; instead it deals with advice on how to get through an unpleasant situation in normal everyday life. ${ }^{85}$ As I have shown, the (mal)practice of angareia was a well-known burden at any time and in any place in the Empire. Matthew's negative tone-he speaks of an evildoer ${ }^{86}$ - merely presumes an encounter with any soldier compelling a civilian to his service. ${ }^{87}$ The forbidden resistance could mean the kind of physical coercion which Apuleius describes, probably without any positive results, as Didache and Epictetus point out. Even the word $\dot{\chi} \chi \theta$ pós in the sixth antithesis fails to refer to warfare. It does not primarily mean a foe in war, which has a word of its own ( $\pi 0 \lambda \varepsilon \dot{\mu} \mu \varsigma)$, but rather a personal enemy. ${ }^{88}$ While this differentiation is not a strict one and there are examples of $\dot{\varepsilon} \chi \theta$ pós being used for a foe in war (e.g., Luke 19:43), ${ }^{89}$ the context here, lacking any reference to war, speaks for the basic meaning.

One further point in the Sermon on the Mount should be treated: the ban on killing in the first antithesis (Matt 5:21-26). Eager to promote pacifism, Cadoux cannot but admit that in the Hebrew Bible the commandment does not cover

84 Theissen 1979, 176-180, 182.

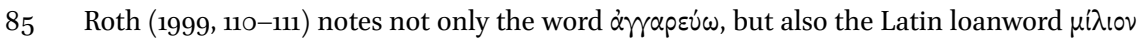
(Lat. mille). He continues by saying: "In first-century Palestine, a Latin loan-word in such a context strongly suggests the 'whoever' in this case represents a military officer. The army was practically the only Latin-speaking Roman institution encountered by common people in Palestine at that time." Roth speaks as if the Greek text would transmit Jesus' actual words, although the gospel is written later and possibly not in Palestine.

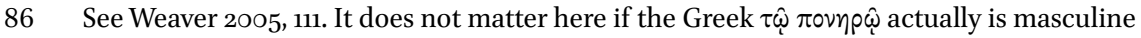
(as the NRSV understands) or neuter (when it should be understood as evil in an abstract and general sense). In both cases, Matthew is describing negative encounters.

87 Brink (2014a, 117) rightly notes that even some civilians could practice angareia. This leads her to an unusual interpretation. According to Brink (2014a, 124-126), the text should be understood metaphorically, referring to the load the scribes and the Pharisees put on others. In reality, angareia was usually associated with soldiers. Because nothing indicates civilians practicing angareia, one should read the common association.

88 This is attested to by Ammonius in his dictionary (Diff. 208) from the 1st or 2nd century.

89 Cadoux 1919, 23 n. 1. 
war, as the word רצח never means killing in the context of military engage-

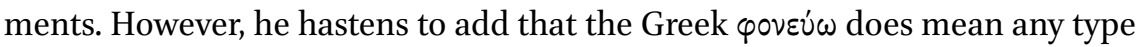
of killing, including killing in war, and that Jesus extended the meaning of the commandments of the Torah. ${ }^{90}$ While this is true, Jesus (as presented by Matthew) extends the meaning of the commandment only in personal relationships: even anger and verbal insults should be counted as killing. There is no hint of war in the antithesis, and I cannot see any intimations in this direction. I thus conclude that the Sermon on the Mount does not bear pacifistic overtones. In this sense it does not speak against the possibility that soldiers belonged to the Matthean community. On the other hand, the implied audience of the Sermon on the Mount consisted of civilians who had to cope with the (mal)practice of angareia. The evangelist gives no advice to soldiers, who are counted as evildoers. Soldiers are evil others for Matthew, though for different reasons than the pacifistic reading suggests. Does this negative picture make it probable that there were no soldiers among the Matthean Christians?

One should not hasten to any such conclusions. An unambiguously positive military figure can be found just after the Sermon on the Mount: the centurion of Capernaum (Matt 8:5-13). Jesus appreciates his faith, which is above all faith in Israel. The centurion is clearly prefiguring gentiles who "will come from east and west and will eat with Abraham and Isaac and Jacob in the kingdom of heaven, while the heirs of the kingdom will be thrown into the outer darkness" (Matt 8:11-12). Who is this centurion? We have to differentiate between the centurion as a possible historical person in Capernaum in Jesus' time and the centurion as a literary figure in the Gospel of Matthew. When speaking of a historical person, we have to be aware that the Roman army was not present in Galilee in Jesus' time when the area was under the rule of Herod Antipas. This is due to the fact that Rome did not station its own army in the client kingdoms. There is no evidence of either Roman troops or coloniae of veterans in this area during Jesus' time. ${ }^{91}$ If the centurion is a historical figure, he cannot be a Roman. Actually, both Matthew and Luke (the other evangelist reporting on the centurion) only assume that the centurion is a gentile. ${ }^{92}$ They do not claim that he is a Roman soldier.

Mark A. Chancey has helpfully analyzed the passage on the centurion in Capernaum. He notes that the Greek word behind the English 'centurion' is not the Latin loanword $x \varepsilon v \tau u p i \omega v$ (cf. Mark 15:39, 44-45), but dependent on

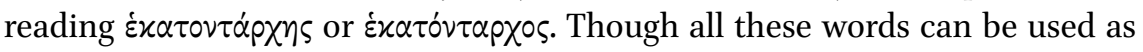

90 Cadoux 1919, 21-22.

91 Chancey 2002, 53-54; 2005, 47-5०, 53; Sanders 2002, 9-13.

92 Saddington 1996, 2413. 


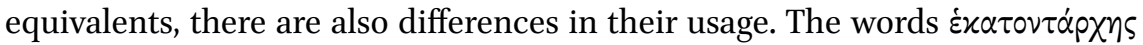

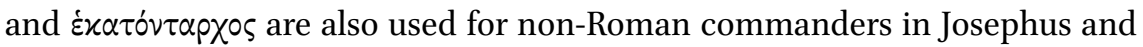
the Septuagint (e.g., Exod 18:21; Num 31:14). ${ }^{93}$ Chancey concludes: "In short, the gospels themselves do not present the centurion at Capernaum as the commander of Roman forces, and it is far more likely that he was a Herodian officer." ${ }^{94}$ It is no surprise that the centurion is a gentile. Antipas' father, Herod the Great, recruited troops from the gentile areas of his kingdom; his bodyguards consisted of Gauls, Thracians, and Germans. It is probable that Antipas also had foreign forces. ${ }^{95}$ What, then, might have been the tasks of a centurion in a fishing village like Capernaum? The presence of a centurion does not indicate any large-scale military troops. The number of soldiers in the command of a centurion could be more or-probable in this case-less than one hundred. As we have seen, centurions had tasks in the local administration. Possibly the centurion in Capernaum was coordinating or safeguarding the toll collection in the nearby border region between Antipas' and Philip's territories. ${ }^{96}$

So much for the possible historical person. Primarily here we can discuss a literary person presented in the gospels. Matthew (or Luke) was conscious of the fact that Galilee was under Antipas' vassal rule during Jesus' lifetime. The changes in the government were rapid after Antipas' reign. Galilee continued to remain under the Herodian dynasty for a couple of years, but then fell to the governance of the Roman procurator (Josephus, Bell. 2.183, 247). These later circumstances may be reflected in the story which Matthew found in the $\mathrm{Q}$ document. Matthew may or may not be thinking of a Roman soldier. In the last analysis, the answer is quite unimportant. Concretely belonging to the Herodian or Roman army seems to make no difference to Matthew. ${ }^{97}$ For him, the centurion is just one person whom Jesus encounters. He lives among

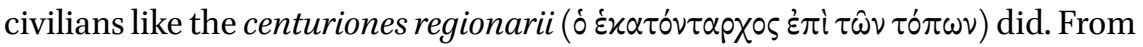
circa $100 \mathrm{CE}$ we have information of this kind of centurionate, whose task was mostly policing. At least in one case a centurio regionarius received praise from the local authorities of the community. ${ }^{98}$ It is possible that Matthew (and Luke) thought of the centurion in Capernaum as a centurio regionarius. Thinking about this happening at the time of the writing of the gospel, this is certainly within the limits of possibility.

\footnotetext{
93 Chancey $2007,5^{2}$.

94 Chancey 2007, 55 .

95 Chancey $2007,51-52$.

96 Chancey 2007, 54-55.

97 See Fuhrmann 2012, 232; Brink 2014, 137.

98 On the centuriones regionarii, see Fuhrmann 2012, 222-224.
} 
From Matthew's point of view, the centurion's profession does not seem to pose a problem. Cadoux is not convinced, however. He points out that it is an argument from silence to claim that a military profession is acceptable. ${ }^{99}$ True, there is no explicit approval of a centurion's profession. However, in this case, the argument from silence has a certain weight. The centurion is clearly an exemplary figure. Could he still be exemplary if his profession were dubious? The calling of Matthew the tax collector makes for a good point of comparison (Matt 9:9-13). Tax collecting was viewed as a dubious profession, coupled with sinning (cf. Matt 11:19), and yet Matthew followed Jesus in an exemplary way. There is, however, a difference between the centurion and Matthew the tax collector: only tax collectors are paralleled with sinners. On the other hand, nothing indicates that the centurion left his post and followed Jesus, while Matthew the tax collector does. Is this an indication that the centurion was left out of the Jesus movement? Probably not. He represents the pagans eating with Abraham and the other patriarchs in the kingdom of heaven.

The centurion is presented as a good guy, while soldiers are hinted at as evil just before in the Sermon on the Mount. This ambiguity is characteristic of the gospel. The reader encounters a similar ambiguity in Matthew's Passion narrative. A whole cohort of soldiers - between 500 and 600 men!100_-mocks Jesus in the most brutal way (Matt 27:27-30). Soldiers mock Jesus as a pretender, however, not as a Son of God. Their ridicule lacks all the religious overtones which are so clear in the comments of the Jewish leaders (Matt 26:59-68). This by no means mitigates the brutality of the soldiers, but it shows up as a meaningful detail when one reads the narrative that follows. After mocking Jesus, the soldiers lead him to Golgotha and crucify him (Matt 27:31-37). Bypassers deride him. The chief priests, scribes, and elders mock him. Even the two crucified bandits taunt him. There are clear religious overtones-even satanic: the phrase "if you are the Son of God" (Matt 27:40) is word-for-word the same as Satan stated earlier (Matt 4:3, 6). ${ }^{101}$ Yet, the soldiers are quiet until the miracles after Jesus' death.

Suddenly the reader encounters a centurion (Matt 27:54). Before that the evangelist has told only of "soldiers" (oi $\sigma \tau p \alpha \tau i \hat{\omega} \tau \alpha)$ in the Passion narrative. Like the centurion of Capernaum, this centurion at the cross represents an exemplary gentile, in opposition to the Jews who abandon Jesus. He and "those with him" — seemingly the rank-and-file men under his command—utter the

99 Cadoux 1919, 33-34.

$100 \operatorname{Luz}(2005,513)$ understands this as an exaggeration.

101 Luz 2005, 538. This is part of Matthew's theological anti-Judaism. See further in Räisänen 2010, 268. 
Christological confession that is reminiscent of the confessions of the disciples (cf. Matt 14:33; 16:16). ${ }^{102}$ The narrative points toward the idea that soldiers can be Christians. They represent gentiles, who can be accepted into the Christian community. In this theological structure their profession is a secondary issue. There is no particular statement on the military profession. Yet, we can again point to what Cadoux falsely discounted as the argument from silence: if these gentiles can prefigure gentile Christianity, then their profession is no stumbling block.

Matthew found the mocking soldiers and the centurion at the cross in Mark. Matthew gave to these figures a distinctive theological role, making two small changes to Mark's story. First, he adds that even the rank-and-file men uttered the Christological confession, while in Mark this was done only by the centurion. Second, Matthew leaves out of his story Mark's account of a centurion who ex officio confirms Jesus' death (Mark 15:44-45). The latter change has no theological weight; it makes the narrative sleeker, as the centurion plays just a technical role in Mark's story, for the agency is in Pilate's hands. The former change, however, cannot be explained as a streamlining of the narrative. The centurion says the essential thing. Why did Matthew make "those with him" join in the Christological confession? The most natural explanation is Matthew's theological agenda regarding Jews and gentiles, which becomes visible when this account is compared to the account of the centurion in Capernaum. When presenting the centurion in Capernaum as an example, Matthew gives a lesson on two groups: "many will come from east and west" (i.e., many gentiles), but "the heirs of the kingdom" (i.e., Jews) are thrown out (Matt 8:11-12). In the Passion narrative, he again presents two groups, Jews and gentiles, with their different relationships to Jesus. The centurion at the cross is not the sole gentile to confess Jesus as the Son of God.

If this was all that Matthew said of soldiers, it would be quite probable that soldiers were welcome to join the Matthean community. The picture, however, becomes more ambiguous because of the epilogue of the resurrection story, which is probably Matthew's own invention. ${ }^{103}$ Here soldiers remind of dark figures in the gospel. First, the soldiers are like the false witnesses whom the Jewish leaders presented in the trial scene (cf. Matt 26:59-61). In

\footnotetext{
102 Luz 2005, 569-570.

103 Luz 2005, 585-587. Luz discusses Crossan's and Koester's hypothesis of the "Cross gospel," which Matthew and the author of the gospel of Peter have used. Luz regards the hypothesis as implausible and thinks that, despite some possible earlier traditions, the pericope is essentially Matthew's creation.
} 
the epilogue, the leaders pay off the guards ${ }^{104}$ of Jesus' tomb to give false testimony (Matt 28:11-15). Second, soldiers are like Judas. They take a large sum of

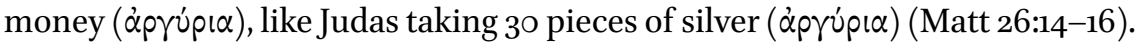
Third, they are counterimages of disciples. The soldiers follow the teaching of the Jewish leaders: "they took the money and did as they were directed $(\delta 1 \delta \alpha \chi \theta \eta \sigma \alpha v)$. And this story is still told among the Jews to this day" (Matt 28:15). Matthew's wording bears the clear weight of biblical language, which he otherwise uses in a positive sense (Matt 1:24; 21:6; 26:19); soldiers are counterimages for the right attitude. ${ }^{105}$

The word $\delta 1 \delta \alpha \sigma \kappa \omega$ is usually translated in biblical texts by the word 'teach.' As the translation of the New Revised Standard Version (the verb 'direct') indicates, this is not the only possibility. Even a less directing tone is possible (e.g., 'advise,' 'inform').106 This makes understandable the use of the verb $\delta 1 \delta \alpha \sigma x \omega$ here. Yet, the choice of the word becomes striking if the reader remembers that it denotes spiritual teaching earlier in the gospel (e.g., Matt 4:23; 5:2, 19; $7: 29 ; 9: 35 ; 13: 54 ; 21: 23)$. The word is even more poignant after one has read the theologically significant ending of the gospel, which follows immediately after the pericope on the bribed soldiers.

Now the eleven disciples went to Galilee, to the mountain to which Jesus had directed ( $\dot{\varepsilon} \tau \dot{\alpha} \xi \alpha \tau 0)$ them. When they saw him, they worshipped him; but some doubted. And Jesus came and said to them, "All authority in heaven and on earth has been given to me. Go therefore and make disciples of all nations, baptizing them in the name of the Father and of

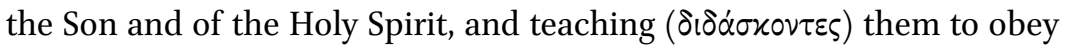
everything that I have commanded you. And remember, I am with you always, to the end of the age."

Matt 28:16-2o

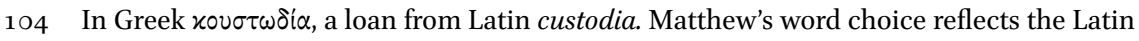
spread by the Roman army.

105 Luz 2005, 611.

106 "At first the soldier resisted and threatened to kill him with his sword, if ever he got to his

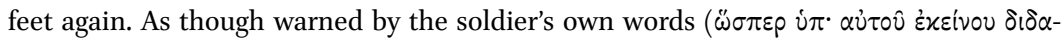
$\chi \theta \varepsilon i(\zeta)$, my master chose the safest course, drew the soldier's sword and threw it a long way off, before ..." (Ps.-Lucian, Asin. 44; trans. MacLeod, LCL). "It was the people itself, as everybody knows, which voted for the government of the Four Hundred, being advised ( $\left.\delta 1 \delta \alpha \sigma \chi^{\prime} \mu \varepsilon v \circ \varsigma\right)$ that the Lacedaemonians would trust any form of government sooner than a democracy" (Xenophon, Hell. 2.3.45; trans. Brownson, LCL). Cf. Liddell, Scott and

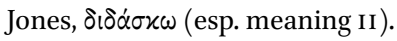


Soldiers are counterimages of Jesus' disciples. Matthew's use of the word $\delta เ \delta \dot{\alpha} \sigma \alpha \omega$ sketches a hazy picture of soldiers sitting at the feet of the Jewish leaders. Soldiers obey the false "mission commandment" of the Jewish leaders-and this is a conscious betrayal, as they saw the miracle at Jesus' tomb (Matt 28:4). There is no trace of the pious confession at the cross. Of course, Matthew could think that the soldiers at the cross were different persons than the guards at the tomb. ${ }^{107}$ But Matthew does not indicate this. Probably he did not bother with a closer identification. However, it seems to be an intentional choice to specify the guards as soldiers. He could have presented Jewish leaders sending their own armed mob, similar to the throng arresting Jesus in Gethsemane: "a large crowd with swords and clubs, from the chief priests and the elders of the people" (Matt 26:47). Remembering Matthew's theological agenda, it would have been logical to assign a Jewish guard to watch over the tomb. A Roman guard made up of soldiers destroys the contradiction between the Jewish and the gentile attitudes toward Jesus. Now they are both against him.

I suggest that there is no longer a need to knit into the figures of soldiers a contrast between Jews and gentiles. The theological agenda is stated openly in themission commandment:one should make disciples of all nations $(\tau \dot{\alpha} \varepsilon \ddot{\theta} \theta \nu \eta) \cdot{ }^{108}$ Matthew does not need believing gentiles, as it is now the future task to make disciples of them. This theological composition does not explain, however, why gentile soldiers are pictured as open allies of the Jewish leaders and spreaders of the anti-Christian lie. Had Matthew wanted to narratively emphasize the future task, he would have presented the soldiers as being more open to the Christian message. Now they are actively resisting it. There must be a reason that explains the negative characterization of soldiers. The answer may partly lie in the political situation. Matthew was writing in the aftermath of the Jewish war. ${ }^{109}$ The Jewish nobility, including high priests and the leading Pharisees, had resisted the war and even asked King Agrippa and the Roman procurator Florus to send troops to smother the rebellion in Jerusalem (Josephus, Bell. 2.411-421). The uprising did not lack elements of class war between the population and the local aristocracy. ${ }^{110}$ From this point of view, the high priests and Pharisees asking Pilate's assistance (Matt 27:62-66) represent nothing but the hated aristocracy allied with the Romans. If this is also Matthew's viewpoint,

\footnotetext{
107 According to Luz (2005, 570), who presents this assumption as an explanation for the ambiguity.

108 Discussing whether Jews can be considered part of the nations, Luz (2005, 628-631) inclines toward the positive. In any case, pagans belong among those who should be made disciples.

109 On the date of writing, see, e.g., Brown 1997, 216-217.

110 Brunt 1990, 272, 282-287.
} 
he exploits the social antipathy to present all claims against Jesus' resurrection in a dubious light.

Yet, we can ask how central a factor were the social antipathies present in Palestine during the Jewish War? Matthew wrote in a post-war situation, probably outside of Palestine. ${ }^{111}$ The political aspect was probably not so intense in Matthew's own social context. Another factor has a much greater explanatory force: the evil reputation of the rank-and-file men (mal)practicing angareia, etc. As soon as Matthew stops needing soldiers to represent the collective of gentiles, this general view becomes visible. Now they serve to cast dubious light on the Jewish leaders. One of the odd sides of the story is the fact that no leader of the custodia is mentioned. The soldiers at the tomb are just "guards" (oi centurion (Matt. 27:54; 28:4). They are also called "soldiers" (oi $\left.\sigma \tau p \alpha \tau i \omega^{\prime} \tau \alpha \mathrm{l}\right)$, like those who mocked Jesus (Matt. 27:27-31; 28:12). Brutal and corrupt soldiers are ready to promote a serious lie for a bribe. No superior is mentioned, which fits well with the ancient stereotypes. The Jewish leaders thus operate with corrupt rank-and-file men; this reveals a great deal about the leaders, reflecting poorly on them.

The distinction between rank-and-file men and their superiors is seen nearly throughout the Gospel of Matthew. ${ }^{112}$ Matthew follows Mark, who already made this distinction and told how the rank and file mocked Jesus, while the centurion confessed his faith at the cross. In Matthew, the exemplary centurions include the one in Capernaum and the one at the cross. No negative superiors are presented, while the rank and file perpetrate angareia, mock Jesus, and promote the anti-Christian lie. The only exception is the guard at the cross, but the positive representation is due to Matthew's theological contrast between Jews and gentiles, and it is not due to any overall positive attitude toward soldiers. At the end of the narrative, the rank-and-file men turn out to be what they were commonly thought to be: greedy, corrupt, untrustworthy, and, in a word, immoral.

So, were there soldiers in Matthew's community? First, contrary to the pacifistic readings, Matthew does not present any principled reason to preclude soldiers from the Christian community. The door was in principle open for soldiers, but it is another question whether any entered. As Matthew's view

\footnotetext{
111 Brown 1997, 212-213.

112 Weaver (2005, 111, 114-116, 121-122) claims that in Matthew's mind, the centurions would generally "appear to be people who inspire the same fear and hatred as their soldiers." As both of the centurions in the gospel are positive characters, I find it difficult to agree with Weaver's view of the general picture.
} 
of rank-and-file men follows the general stereotype, this does not speak for a personal knowledge of soldiers joining the faith. In turn, the images of centurions are highly positive: they believe in Jesus. Remembering that these men just represent gentiles in Matthew's narrative, we should not read too much into their military profession. However, the profession of exemplary gentiles cannot be entirely without relevance. Matthew gets these figures or at least part of them from his sources, but they would have been more strongly rewritten had they not been acceptable. This fits well with the information of positive interactions between centurions and the local people. In sum, Matthew held the door open for soldiers, but anticipated them with an ambiguous mind. He did not foresee that brutal rank-and-file men would enter the community, and he expected more of centurions. In the narrative world, two centurions entered. This reflects Matthew's expectations of his social context, if not beyond. Most scholars assume that Matthew wrote in Antioch. ${ }^{113}$ A big garrison was located there and, thus, Matthew surely had lived experiences of soldiers.

\subsubsection{Luke's Exemplary Soldiers}

In the Gospel of Luke, the reader encounters several military figures known from Matthew. However, the story is not the same. Luke does not just repeat the same stories but presents his own versions, leaving some figures unmentioned and adding a group of soldiers to the opening of his Gospel. After the infancy stories, where a heavenly army has praised God (Luke 2:13), Luke recounts the preaching of John the Baptist and tells of the reaction of the listeners, among whom one encounters soldiers present in neither Mark nor Matthew.

And the crowds (oi o' $\chi \lambda \circ$ ) asked him, "What then should we do?" In reply he said to them, "Whoever has two coats must share with anyone who has none; and whoever has food must do likewise." Even tax-collectors came to be baptized, and they asked him, "Teacher, what should we do?" He said to them, "Collect no more than the amount prescribed for you."

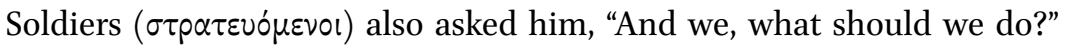
He said to them, "Do not extort money from anyone by threats or false

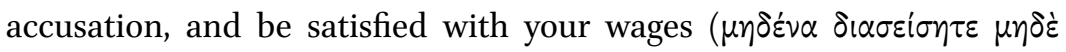

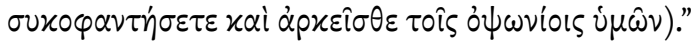

Luke 3:10-14

There are three groups here: crowds, tax-collectors, and soldiers. I suppose that this indicates everyday life; the crowds can be interpreted as the common

113 Brown 1997, 212. 
people with matters of adequate livelihood and clothing, and tax collectors and soldiers were officials met in everyday life. It is not problematic that these officials are mentioned together, because soldiers could safeguard taxation. ${ }^{114}$ MacMullen vividly describes gross abuse on the part of soldiers and tax collectors.

At Mendechora, stationarii and kolletiones, threatening reports to their superiors or imprisonment, practiced a diaseismon, a "shakedown," upon the whole village; nearby, nine men were imprisoned and only one released, for a thousand drachmas; a third neighboring village was loaded "with insupportable burdens, exhausted by unlimited expenses of these sojourners and for the hordes of kolletiones is deprived also of its baths due to its depleted condition, and deprived too of the necessities of life."115

Stationarii were soldiers scattered around in minor posts, stationes. MacMullen describes their ill repute: "It is natural that they should have made themselves unpopular, taking the oxen from the fields, and so forth."116 In other words: they perpetrated angareia. The other group mentioned, kolletiones, were tax collectors or their helpers. ${ }^{117}$ Interestingly, MacMullen describes soldiers and tax collectors in cooperation, just as Luke seems to presume. This cooperation is even philologically visible in the words $\sigma \cup x \circ \varphi \alpha \nu \tau \varepsilon \dot{\varepsilon} \omega$ and $\delta\llcorner\alpha \sigma \varepsilon i \omega$, which John the Baptist uses to refer to soldiers' questionable activities, as such terms not only apply to soldiers but also tax collectors. Zacchaeus the tax collector uses $\sigma \cup x \circ \varphi \alpha \nu \tau \varepsilon^{\varepsilon} \omega$ to admit that he has "defrauded" people (Luke 19:8). The other verb, $\delta ı \sigma \varepsilon i \omega$, is the semiofficial term for extortion. ${ }^{118}$ Its cognate, $\delta 1 \alpha \sigma \varepsilon ı \sigma \mu o ́ s$, appears in MacMullen's description, denoting the joint activities of soldiers and tax collectors. Luke parallels $\sigma u x \circ \varphi \alpha \nu \tau \dot{\varepsilon} \omega$ with $\delta ı \sigma \varepsilon i \omega$, which is somewhat pleonastic but not unique in the ancient literature. ${ }^{119}$ The verbs as such do not necessarily refer to the extortion of money or goods but the end of the

114 Nolland 1989, 150; Pollard 2000, 101.

115 MacMullen 1963,87 . The text is from the third century. The serious illegality it recounts may mirror the increasing disorder in the Empire (Fuhrmann 2012, 220).

116 MacMullen 1963, 55-56. See also Brink 2014, 169.

117 MacMullen 1963, 87 n. 38; Fuhrmann 2012, 218-220.

118 MacMullen 1963, 87 n. 38; Brink 2014, 76.

119 Brink 2014, 101. Cf. Antiphon, De Choreuta 43, where $\sigma \varepsilon i \omega$ and $\sigma u x \circ \varphi \alpha v \tau \omega$ are used in parallel with a similar meaning, and Liddell, Scott, and Jones 2011 on $\delta\llcorner\alpha \sigma \varepsilon ı \sigma \mu o ́ s . ~ Z e i c h m a n n$ $(2019,46)$ claims that $\sigma u x \circ \varphi \alpha \nu \tau \varepsilon \dot{ } \omega$ "denoted false charges against the wealthy, evident in perusing use of the term in documentary papyri and literary texts of the period." This is incorrect, as Prov 14:31, 22:16, and 28:3 (LXX) put "a poor one" as object of the verb. 
sentence makes this meaning incontrovertible. ${ }^{120}$ The verb $\delta$ เ $\sigma \varepsilon i \omega$ refers to violent means of extortion, while $\sigma u x \circ \varphi \alpha v \tau \varepsilon \dot{\omega} \omega$ alludes to false accusations. As we saw earlier, extortion and other injustices were a real threat in the Roman East. Thus, Luke 3:14-like Matthew 5:41-refers to common problematic encounters between soldiers and local people.

However, there are three noteworthy differences when Matthew 5:41 and Luke 3:14 are compared. First, Matthew speaks of angareia, while Luke refers most probably to soldiers' activities in taxation. This is not a large difference, as people surely felt angareia and taxation to be two aspects of the same burden. Second, Matthew does not make a distinction between lawful and unlawful angareia, both being bad without qualification. Luke refers only to clear crimes, hinting that soldiers can blamelessly fulfill their tasks. Third, Matthew sees soldiers practicing angareia as people one simply has to cope with, not expecting any change in them. Luke is not so pessimistic. He describes soldiers as asking guidance from John the Baptist-possibly with the intention to become baptized. Luke paints a picture of soldiers who may become good. This is in line with his emphasis in the gospel as whole, where repenting sinners, like Zachaeus the tax collector, are recurring figures and paradigms of real followers of Christ. ${ }^{121}$ Luke's positive view of soldiers is here in nuce. One will encounter this positive trait also later in the gospel and in Acts.

The positive trait becomes clearly visible in the next Lukan passage on a soldier, the centurion of Capernaum (Luke 7:1-10). This is no surprise after one has noted the general tendency in ancient texts to depict centurions positively. As we have seen above, the common people could feel some kind of trust toward centurions, who often had economic resources. While in the Matthean parallel the centurion of Capernaum is exemplary, Luke's centurion is even more so. Laurie Brink says that the evangelist characterizes him in encomiastic terms. ${ }^{122}$ In Luke's version, the centurion never meets Jesus but communicates with him via Jewish elders and friends. The elders praise the centurion as a wealthy benefactor in the local community. ${ }^{123} \mathrm{He}$ is clearly not a Jew (7:9), but he "loves our people, and it is he who built our synagogue for us."

120 The NRSV speaks only of extorting money. This is possibly due to translating ó $\psi \omega \dot{v}$ เov as 'wages.' Yet, ó $\psi \omega \dot{\omega} v i o v$ probably means provisions in a more general sense. For the meaning of ó $\psi \omega \dot{\omega} v i o v$, see Caragounis' (1974) careful examination. He proposes the following translation for the Lukan sentence "Do not by applying violence rob anyone, nor slander anyone with a view to possible gain, and be content with your own provisions/shoppings" (Caragounis 1974, 51).

121 On Luke's interest in sinners and their repentance, see Pesonen 2009.

122 Brink 2014, 163.

123 There are examples of gentiles founding a synagogue. See Nolland 1989, 317. 
The words may support the idea that the centurion is a God-fearer-whatever this means in practice. As I noted earlier, soldiers could honor local deities alongside state and military deities. Loving Israel and building a synagogue can also imply good relations with the local people.

One can question Luke's picture from a historical point of view. Can a centurion afford to build a synagogue? ${ }^{124}$ Is it credible that a centurion in pre-war Galilee had such a good relationship with the local Jews? Before $44 \mathrm{CE}$, the soldiers in Galilee were Herod Antipas' men, who were known for their antiJewish attitudes (cf. Josephus, Ant. 19.356-359). Could there be an exception? These questions are secondary, as I try to understand Luke's message rather than the historicity of his account. Because Luke wrote outside of Galilee after the Jewish war, ${ }^{125}$ for him the centurion primarily served as a religious example for the audience of the Eastern Mediterranean area; he may have thought about a Roman soldier, which suited his political purposes. ${ }^{126}$ There are examples of wealthy centurions serving as benefactors and funding local sanctuaries. ${ }^{127}$ Thus, the prestigious status of the centurion in the local community is credible in light of what we know about Roman centurions. Martin Goodman notes that Jews even tried to find sympathizers of their religion in order to build useful social links. ${ }^{128}$ Early Christians surely had similar goals.

In the narrative, the centurion's office and economic resources secure him a powerful status in Capernaum. He can send a Jewish delegation to represent himself, which proves his authority among the local people. Seemingly the centurion is a patron to them. ${ }^{129}$ In this context the word "friends" ( $\varphi$ i $\left.\lambda \circ \iota\right)$ probably does not indicate equality between the friends and the centurion, but loyal relationship between patrons and clients. ${ }^{130}$ What makes the centurion so exemplary is his humble attitude toward Jesus. His socially high status emphasizes the humility. While the Jewish delegation describes him as worthy ( $\dot{\alpha} \xi$ เós) of Jesus' help, the centurion claims to be unworthy: "I am not worthy (o

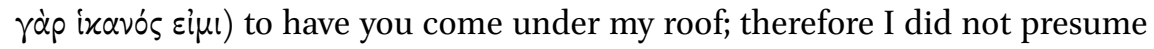

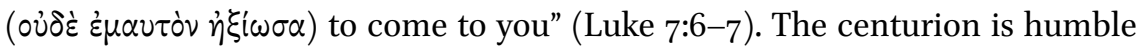
like the tax collector praying in the temple (Luke 18:9-14), but they are not comparable in every respect. In the story of the praying tax collector, a Pharisee

\footnotetext{
124 Wegner 1985, 257-259.

125 Brown 1996, 269-271, 273-274.

126 Kyrychenko 2014, 154-155.

127 Kyrychenko 2014, 156.

128 Goodman 1994, 87-88.

129 Moxnes 1991, 65; Hobbs 2001, 333.

130 Stählin 1974, 147, 159. Aristotle explains the several types of friendship. Among others he mentions the one between unequal persons (Eth. Nic. 1158b-1159a).
} 
pairs tax collectors with thieves, rogues, and adulterers (Luke 18:11; cf. 15:1). Similarly in the story of Zaccheus the tax collector, he confesses fraud (Luke 19:8). The centurion, in comparison, bears no trace of immoral behavior. There does not seem to be anything dubious in his past or present. He is exemplary in a different way than the repenting sinners. ${ }^{131}$ Therefore, even his military profession cannot be brought into question. If it was, the centurion could not be the exemplary believer, if he did not repent. Luke probably did not see any obstacles for a centurion to be a member of the Christian community.

The following soldiers in the gospel are not positive, however. In the story of Judas' betrayal, Luke adds military figures that are absent from the other gospels. These figures are officers ( $\sigma \tau \rho \alpha \tau \eta \gamma o i$ ) who appear on the side of the chief priests and the elders (Luke 22:4, 52). As the latter occurrence clearly indicates, Luke means the officers of the temple police. ${ }^{132}$ One can only speculate why Luke added the officers. Possibly it has something to do with the fact that Roman soldiers are reduced in the Lukan passion story. The soldiers mocking Jesus are not Roman soldiers but belong rather to Herod's men (Luke 23:11).133 The odd absence of Roman soldiers continues when Pilate reluctantly hands Jesus over-to translate it literally- "to their will" ( $\tau \hat{\omega} \theta \varepsilon \lambda \dot{\eta} \mu \alpha \tau \iota \alpha \dot{\nu} \tau \hat{\omega} v)$ (Luke 23:25). Luke continues that "they" (using only verbs in the third-person plural) led him away. "They" also put the cross on Simon of Cyrene, but-and this catches the eye of the reader-Luke (23:26), unlike Mark (15:21) and Matthew (27:32), avoids the verb $\alpha$ rrapevi $\omega$ and the impression of an official procedure which that verb would give. As Jesus is brought to Golgotha, "they" even put Jesus and the two criminals on the cross. The people see what is happening and the leaders scoff at Jesus. Only after he has been crucified do the soldiers suddenly appear to mock ( $(\dot{v} \varepsilon \dot{\tau} \pi \alpha \xi \alpha \nu)$ him (23:36). ${ }^{134}$ The reader's first association

131 Pace Brink (2014, 175), who sees soldiers and tax collectors in a similar category of sinners to be exonerated by Jesus.

132 Scholars have identified them as officials in the temple (Wolter 2008, 693-694), but the textual context clearly refers to temple police. As Nolland (1993, 1030) says, "their importance is surely related to their ability to set in motion the arrest of Jesus."

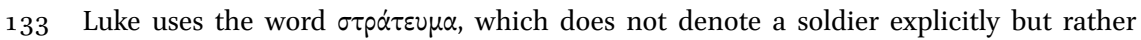
a group of soldiers, a military unit (cf. Acts 23:10, 27), without defining its strength (Bauernfeind 1971, 702, 709 n. 34). The plural form indicates several units, in this case surely the detachments in Herod's bodyguard.

134 The mocking soldiers offer coarse (poor quality) wine (o' $\xi \circ \varsigma$ ), which was usual among the military (Nolland 1993, 1147). It might be a merciful act, but Luke possibly had in mind Ps 68:22 (LXX), where inferior wine is offered as part of a mocking performance. 
is with the previously mentioned soldiers, namely Herod's contingent, who mocked ( $\left.\dot{\varepsilon} \mu \pi \alpha^{\prime} \xi \alpha \varsigma\right)$ Jesus. ${ }^{135}$

Who actually are the nameless "they" to whose will Pilate hands Jesus over? In the textual context they are the chief priests, leaders, and the people (Luke 23:13), who all ( $\pi \alpha \mu \pi \lambda \eta \theta \varepsilon i$ ) required Jesus' death (Luke 23:18). Thus, it seems as if Jesus was crucified by the chief priests, leaders, and the people (cf. Acts 5:30). This is anything but clear, however. In the Gospel of Peter, Herod (not Pilate!) commands people to execute Jesus, but there is no similar authorization in Luke's account. The handing over of Jesus "to their will" can actually mean that Pilate did "as they wished."136 Ancient people might have thought that only Roman officials had the right to execute Jesus (cf. John 18:31). In fact, "they" indicate that the decision of execution was Pilate's responsibility, as "they" shout: "Crucify, crucify him!" (Luke 23:21; cf. 23:18). It is also quite odd that the subject of the verbs in the third-person plural is never mentioned again after Luke 23:13. It is possible that the third-person plural is used to express a more general agency. In other words, one could translate the active voice with the passive one without violating Luke's idea. ${ }^{137}$ It is as though Luke does not wish to pinpoint those very persons who are responsible for executing Jesus' death sentence. There are reasons to believe that they were not what a mechanical reading of the third-person plural presumes. One could naturally accept that the executioners were the soldiers of the local prefect, but Luke carefully avoids saying this in explicit terms. When the soldiers suddenly appear to mock Jesus, their actual task there is left in obscurity. The reader easily associates them with the soldiers of the tetrarch. With regard to Jesus' death, therefore, Luke tries to obscure the role of the Romans in the shadows.

After Jesus' death, there is another military figure at the cross, a centurion who immediately praises God and confesses: "Certainly this man was innocent

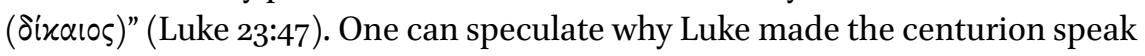
of an innocent (or righteous) man — not the Son of God, as seen in Mark and Matthew. Probably it has something to do with what Pilate said earlier: Jesus is not guilty (Luke 23:4,14,22). Similarly, the repenting criminal attests that

135 Brink (2014, 104-105) and Kyrychenko (2014, 148-149) assume that the soldiers at the cross are Romans. Both are aware of the problematic identification and mention it in footnotes. Only Kyrychenko gives reasons for his interpretation, saying that the parallel accounts and the presence of a centurion make it impossible to speak of Herod's soldiers or the temple police. I do not see why parallel accounts (in other gospels?) should rule out what Luke says or why a centurion could not serve in other than Roman troops.

136 Wolter 2008, 751.

137 Nolland (1993, 1136) speaks of Luke's grammatical carelessness. See also Smyth 1984, 259 (§ 931d). 
Jesus has been unjustly condemned. Pilate, the centurion, and the repenting criminal make the same claim regarding Jesus' blamelessness. ${ }^{138}$ As the repenting criminal is clearly a paradigmatic figure for Christians, ${ }^{139}$ one can assume that the centurion is of the same type. At the cross, the reader of Luke's gospel encounters again the ancient dualism commonly seen between rank-and-file men and centurions. The former mock Jesus, while the latter is a more positive figure. Earlier in the passion narrative the officers of the temple police are negative figures, but this is because they assist Jesus' opponents. The different evaluations of military persons depend on their status or their task, not on their profession as soldiers per se. Here the modern scholarship usually strays, arguing for acceptance or rejection of the military profession. For Luke the problem seems not to be soldiers as such, but unjust soldiers. As an ancient person, he tended to think of rank-and-file men in those terms, but believed that even they could become just (Luke 3:14).

It will suffice to make a few short comments on soldiers in Acts, which support my observations on the gospel. First, the temple police are hostile to Christians (Acts 5:23-26), as in the gospel. Second, there are soldiers who are just doing their work and are mainly extra figures $(24: 22-23 ; 27: 1,11,31-32$; 28:16). For example, Herod's soldiers guarding Peter in prison emphasize the miracle. ${ }^{140}$ Peter succeeds in escaping while the guards are sleeping, which leads to their execution for lack of vigilance (Acts 12:6-19). ${ }^{141}$ Third, in Acts, Roman soldiers are mainly described in a positive light. One may surmise that Luke's positive attitude toward Roman soldiers can already be seen from their absence in the passion story in the gospel. The third point deserves more attention. Roman soldiers protect Paul against the Jews (Acts 21:31-40; 22:24-29, 30; 23:10, 15, 17-35), and Luke finds only minor faults in them. Julius the centurion "treated Paul kindly," but makes the mistake of not believing Paul's weather report (Acts 27:3, 11). Later he protects Paul and other prisoners against guards who wanted to kill them, fearing their escape (Acts 27:42-43) — a very understandable reaction on the part of the soldiers (cf. Acts 12:19). Otherwise, Paul almost always engaged with members of high society (e.g., Felix, Festus,

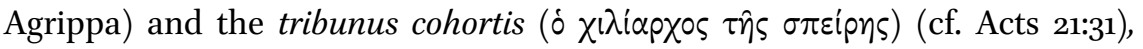
the leader of the Roman troops in Jerusalem. ${ }^{142}$ Paul is brought to Ceasarea in the custody of a mixed unit of infantry and cavalry. Luke even states the

\footnotetext{
138 Brink $(2014,171)$ notes only Pilate and the centurion.

139 Syreeni 1991, 47-49; Pesonen 2009, 215-216.

140 Barrett 2004, 579.

141 It is uncertain if Luke really means execution with the verb $\dot{\alpha} \pi \alpha \chi \theta \hat{\eta} \nu \alpha$ l, but it is probable in this context (Barrett 2004, 588).

142 On the tribunus, see Tajra $1989,67$.
} 
strength of the force ( 470 men). The level of security employed to protect Paul against the Jewish conspirators clearly emphasizes his importance.

While the overall picture of Roman soldiers in Acts is positive, the value placed on Cornelius the centurion (Acts 10) is the greatest. He is probably presented as serving in the Cohors II Italica voluntariorum civium Romanorum, an auxiliary troop. The name of this unit indicates that it recruited Roman citizens, placing it in the superior category of auxiliary regiments. On the other hand, the name could have been an honorary title, with soldiers who were non-citizens recruited locally in the East. ${ }^{143}$ These historical details have minor importance for Luke, however. Key here is that Cornelius was a Roman soldier and the first gentile Christian. ${ }^{144}$ He was "a devout man who feared God" (Acts 10:2) already before his conversion. The stumbling block which Luke pushes aside in the account of Cornelius' conversion is not his military profession, but the fact that he is not a Jew. The whole account tries to argue that a non-Jew can be a Christian. The military profession is quite inessential in the conversion story of Cornelius, as no questions are raised in terms of this.

When commenting on the stories of Cornelius and other military figures in the New Testament, Harnack claims that they "are not told in order to praise the military profession or even to suggest toleration. That they were soldiers in all these cases was of minor importance for the teller of the story."145 The last statement makes clear why Luke welcomed soldiers into the Christian community. Cornelius' profession is of no consequence for the evangelist, who indicates toleration. ${ }^{146}$ The case is so clear that even a pacifist, like Cadoux, can see it. He writes on Cornelius and the jailer $(\delta \varepsilon \sigma \mu \circ \varphi \dot{\nu} \lambda \alpha \xi)^{147}$ in Philippi (Acts 16:23-34), connecting them with the soldiers who posed a question to John the Baptist (Luke 3:14):

The New Testament itself and the earliest Christian literature nowhere express disapproval of the continuance of these men-assuming they

143 Saddington 1996, 2415-2416; Kyrychenko 2014, 39-40. Brink (2014, 151-152) assumes that Cornelius was a veteran.

144 See Brink 2014, 154. Kyrychenko (2014, 164) notes that the place, Caesarea, is hardly coincidental. The city was the Roman capital in Judea.

145 Harnack 1981, 70.

146 Later Harnack $(1924,578$; the previous citation is from Militia Christi, which was originally published in 1905) relayed that there was no problem of Christian soldiers ("eine christliche 'Soldatenfrage'") before Caesar Marcus Aurelius.

147 Some jailers were soldiers, but slaves and civilians were also employed to this end. The jailer in Philippi, under the duoviri ( $\sigma \tau p \alpha \tau \eta \gamma o i$ ) city authorities, heeds the commands of

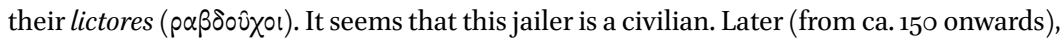
the city prison came more strongly under military command. For more on prison guards, see Krause 1996, 252-264. 
did continue - in their calling, or of the military calling in general. It is even possible that Luke, who records these cases, as well as the conversation between John the Baptist and the soldiers, may have meant to intimate thereby his view as to the propriety of admitting soldiers to the Church without requiring them to abandon the profession of arms: and the existence even of these few cases makes it possible that from the earliest times there may have been soldier-converts in the Church. ${ }^{148}$

Cadoux's reserved attitude - "there may have been soldier-converts" - is wellgrounded, as we should be cautious with the historical reliability of all the details in Acts. Scholars have justly asked whether Cornelius and the jailer in Philippi are historical figures. ${ }^{149}$ But if they are not historical, the author has intentionally created them. If this is the case, their profession may not be so inconsequential, as Harnack claimed. If Cornelius is Luke's innovation, why did he choose a soldier to be the first non-Jewish Christian? Why not another gentile in Caesarea? If Cornelius is an imaginary figure, Luke's choice could attest to the fact that he at least hoped there would be soldier converts.

In sum, it is characteristic for Luke to maintain the reputation of the Roman soldiers. Herod's soldiers or the temple police are presented in a less favorable light. This distinction is seemingly based on political needs. Alexander Kyrychenko puts it as follows: “The Roman Empire in Luke's narrative is a receptive mission field, and the Roman centurion, the principal representative of the Empire, exemplifies the desired response."150 Otherwise Luke presents the standard distinction between rank-and-file men and their superiors. At the very least centurions were clearly welcomed into the Christian community. This is commensurate with Mark and Matthew. While Matthew seems to have reservations regarding rank-and-file men, Luke hopes that even they can be converted, as the admonition addressed to them assumes (Luke 3:14). ${ }^{151}$ In Acts, Luke also reports on a baptized soldier. Why, then, would there not have been any in his own day? Luke would have accepted them if there had been any. However, it is noteworthy that he assumes his readers to be civilians. In the synoptic apocalypse, Luke presents Christians in the midst of a war. There is no hint of Christian soldiers, but rather refugees of war: "When you see Jerusalem

\footnotetext{
148 Cadoux 1919, 228-229.

149 On Cornelius, see, e.g., Haenchen 1982, 355-362, and Barrett 2004, 491-497. One can question if Cornelius' troop was really stationed in Caesarea at that time: "It may be that circumstances prevailing at a later period were assumed to have existed at an earlier one" (Schürer 1973, 364-365). On the jailer, see, e.g., Haenchen 1982, 355-362.

150 Kyrychenko 2014, 189.

151 See Brink 2014, 175. Zeichmann $(2019,46)$ argues that Luke tries to put the rank and file in their place with the poor while presenting the values of the wealthy elite.
} 
surrounded by armies, then know that its desolation has come near. Then those in Judea must flee to the mountains, and those inside the city must leave it, and those out in the country must not enter it" (Luke 21:20-21). If there were Christian soldiers in Luke's community, they must have been exceptions.

\subsubsection{John's Soldiers Fulfill Prophecies}

In the Gospel of John, soldiers are like puppets on a string. They behave as God has planned, acting in a deterministic drama where Christ is to be crucified and then lifted to heaven. Soldiers appear only in the passion story. Their march to the stage is massive: a cohort ( $\sigma \pi \varepsilon i p \alpha)$ led by a tribunus cohortis ( $\delta \chi 1 \lambda i \alpha p X \circ \varsigma)$, come to arrest Jesus along with servants $(\dot{v} \pi \eta \rho \varepsilon \dot{\tau} \tau \varsigma)^{152}$ of the Pharisees and high priests (John 18:3, 12). Thus, Jews and Romans cooperate in the arrest. ${ }^{153}$ The Jewish-Roman cooperation is surprising. In the story of the arrest, John refers to a Jewish plan to seek Jesus' death: Jews were afraid of the Romans and they planned Jesus' death to avoid national destruction (John 11:47-50; 18:14). Thus, the cooperation does not reflect a good or confidential relationship between Jewish leaders and Romans. Pilate will be won over to the side of the Jews only later (John 18:28-19:18). Nonetheless, a whole cohort assists in the arrest of Jesus. How can a cohort be united with Jews in this situation? The answer involves Judas: he-and no one else- "took" ( $\lambda \alpha \beta \omega \dot{\omega} v)$ the cohort and the servants as though he were the real leader. This might be an overinterpretation of a single verb, ${ }^{154}$ if one were to forget that Judas plays the part of Satan (John 13:27). Being that Satan is the ruler of this world (John 12:31; 14:30; 16:11), he can recruit these massive forces against Jesus. ${ }^{155}$ Still, in the last analysis, God pulls all the strings: everything happens as he has planned. ${ }^{156}$

$15^{2}$ Not 'police,' as the NRSV translates. It is surely possible that John is thinking about the

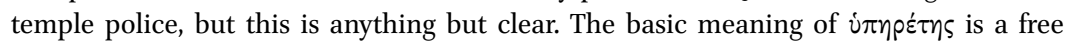

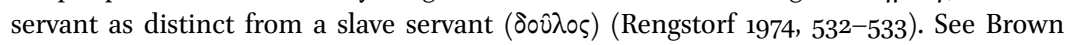
1970, 314 .

153 Quite similarly, see Beasley-Murray 1999, 322.

154 This kind of criticism of my interpretation is quite common. For most interpreters, the verb indicates that Judas showed the way (see, e.g., Carson 1991, 577; Beasley-Murray 1999, 322 ). The meaning of the verb, however, requires more (see Brown 1970, 807).

155 Lindars (1972, 539-540) sees here a symbolic dimension: both religious and secular powers stand against Jesus. Theissen $(1999,203)$ claims that "a cohort can be commanded only by someone who has a Roman mandate" and, thus, Judas' satanic power is also the Roman power, haunted by the words "the ruler of this world." On the other hand, Hakola (2005, $205 \mathrm{n}$. 15) comments that neither John nor the other references to the devil in the Jewish or Christian sources support Theissen's interpretation.

${ }_{15} 6$ On John's dualism and its relationship to his idea of God's governance, see, e.g., Hakola 2005, 197-210. 
Soldiers appear again on the scene when Jews try to induce Pilate to pass a death sentence on Jesus. Pilate is reluctant and flogs Jesus; this surely means that he ordered soldiers to do the flogging (John 19:1). The flogging is an odd turn, as Pilate saw no case against Jesus (John 18:38; 19:4). Did he hope that the Jews would be satisfied with flogging only? ${ }^{157}$ Be that as it may, soldiers properly humiliate Jesus: they not only flog but also mock him. ${ }^{158}$ The mocking itself resembles the descriptions in Mark and Matthew and their view on soldiers. When analyzing Mark's story, I showed that the description corresponds to the normal ancient view of rough rank-and-file men. As Pilate finally assents to execute Jesus, John's story continues as if the Jews crucified Jesus. After stating that Pilate discusses with the Jews and the chief priests, John continues by saying that Pilate handed Jesus over "to them to be crucified. So they took Jesus" (John 19:16). The reader gets the impression that the Jews took Jesus. This is the impression even at Golgotha, where "they" crucify Jesus and two other men (John 19:18). I showed above that Luke possibly tried to blot out the role of soldiers. There is seemingly no similar motive behind John's story, as he later openly states that soldiers crucified him (John 19:23). ${ }^{159}$ The appearance of the third-person plural in John 19:16 and 19:18 is imprecise usage and actually refers to soldiers.

After the crucifixion, soldiers appear twice to assure the reader that it is God who pulls the strings. Soldiers fulfill prophecies: ${ }^{160}$

When the soldiers had crucified Jesus, they took his clothes and divided them into four parts, one for each soldier. They also took his tunic; now the tunic was seamless, woven in one piece from the top. So they said to one another, "Let us not tear it, but cast lots for it to see who will get it." This was to fulfil what the scripture says, "They divided my clothes among themselves, and for my clothing they cast lots." And that is what the soldiers did.

John 19:23-24

\footnotetext{
157 Thus see, e.g., Brown (1970, 886) and Beasley-Murray $(1999,334)$.

$15^{8}$ Beasley-Murray $(1999,336)$ regards the mockery as "motivated by a spontaneous desire for some crude and cruel horseplay."

159 In principle, it is syntactically possible to read John 19:23 in a way that soldiers did not

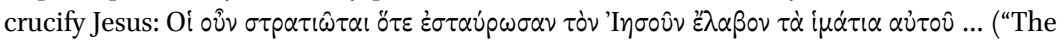
soldiers, when they (i.e. the Jews) had crucified Jesus, took his clothes ...") This translation, however, is against all probability and would be forced.

16o Brown 1970, 913 .
} 
Then the soldiers came and broke the legs of the first and of the other who had been crucified with him. But when they came to Jesus and saw that he was already dead, they did not break his legs. Instead, one of the soldiers pierced his side with a spear, and at once blood and water came out. (He who saw this has testified so that you also may believe. His testimony is true, and he knows that he tells the truth.) These things occurred so that the scripture might be fulfilled, "None of his bones shall be broken." And again another passage of scripture says, "They will look on the one whom they have pierced."

John 19:32-37

Everything happens according to the divine plan, and soldiers play their role, as it is written. This, however, is no positive statement regarding soldiers. All the protagonists, even the Jews striving for Jesus' death, are part of this plan (John 11:51-52), but this does not mean that every character in the gospel is a good one. The reader cannot miss the fact that the Jews are dark characters with nefarious motives. ${ }^{161}$ This is clear throughout the gospel, hitting an apex when Jesus says to the Jews: "You are from your father the devil, and you choose to do your father's desires" (John 8:44). Does the statement about the Jews apply also to the soldiers? Yes and no. On the one hand, in John's dualism the soldiers fall on the side opposing Jesus, as the story of Jesus' arrest clearly presupposes. On the other hand, one can see that soldiers are like extra figures. One can also perceive that the evangelist's attitude toward Pilate is more lenient than toward the Jews. John lets Jesus say to Pilate: "the one who handed me over to you is guilty of a greater sin" (John 19:11).162 If one were to extend any conclusion to the soldiers, it would mean that John's attitude was similarly lenient to them.

Despite these mitigating circumstances, one must conclude that in John's dualism, soldiers were against Jesus. Moreover, fighting is not found among

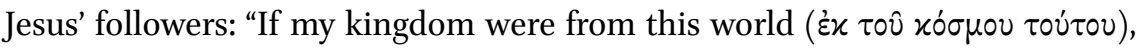

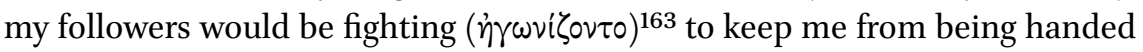
over to the Jews. But as it is, my kingdom is not from here" (John 18:36). Is it possible to soften this statement by claiming that fighting is out of place in

\footnotetext{
161 On the Jews in John, see Hakola 2005.

162 "The one who handed me over to you (Pilate)" cannot refer to Judas, as he did not hand Jesus over to Pilate but to the Jews (Morris 1995, 705). The reference is possibly to Caiphas or to the leading Jews as a collective (Brown 1970, 878-879; Beasley-Murray 1999, 340).

163 'To fight' is the only possible meaning of the verb in this context. The basic meaning of $\alpha \gamma \omega v i$ ' $о \mu \alpha \iota$ is 'to contend,' especially in games. Yet, the meaning 'to fight' is well known, even in early documents (e.g., Herodotus). See Liddell, Scott, and Jones 2011, $\alpha \gamma \omega v i \zeta o \mu \alpha \iota$.
} 
this situation? In other words, one would see Jesus' crucifixion as a part of the divine plan, which Jesus' followers accept without resistance, while fighting would be allowed in other situations. This is not a possible reading, however. After reading the Gospel of John to this point, one cannot miss that the "world"

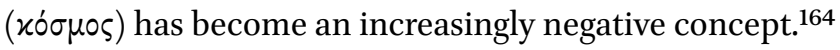

In the opening hymn, the world is made by God through the logos (John 1:10). A little later, it is said that the world is the object of God's love. Jesus came to bear the sins of the world and save it (John 1:29; 3:17). Despite this basically positive aspect, one cannot miss the fact that there is something seriously wrong in the world. The negative trait becomes clearer as the story proceeds toward Jesus' death. It is illustrative that Jesus proclaims his victory over the world (John 16:33) as though it were his enemy (though he earlier was meant to save it!). A similarly oppositional situation is encountered when Jesus says that he does not pray for the world (John 17:9). Now it is no more the world which will be rescued, but the believers who are rescued from the world. In this context, it is difficult to avoid the conclusion that fighting is something entirely negative, as it belongs to the world. Moreover, Jesus speaks of his non-fighting follow-

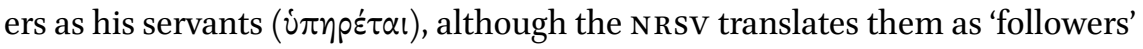
(John 18:36). The use of the word 'servant' possibly equates Jesus' followers with those servants who came to violently arrest Jesus (John 18:3, 12). ${ }^{165}$ In this light, it is difficult to imagine a soldier in a Johannine community.

This Johannine background also sheds light on the story of the royal official (John 4:46-54). This story is dependent on the same tradition as the synoptic parallels, ${ }^{166}$ but John either changed the centurion into the official or he was influenced by a variant of the tradition where there was no centurion. ${ }^{167}$ The choice between the two alternatives is highly speculative. However, it is worth noting that the other believing centurion of the synoptic tradition is missing from John, namely, the centurion at the cross. ${ }^{168}$ One can sense the reason after reading the Johannine passion story where the soldiers belong to the world. Believing soldiers simply do not fit with John's dualistic drama. This makes it improbable that the official is a soldier; although the Greek word $\beta \alpha \sigma i \lambda$ เxós can mean a wide range of professions in royal service, including the military

\footnotetext{
164 Schnackenburg $(1986,285)$ sees the world in John in a more positive light than I do.

165 Morris 1995, 680 n. 85.

166 Dunderberg $(1994,74-97)$ supposes that John probably knew the parallel stories.

167 The centurion seemingly was present in Q (see Robinson, Hoffmann, and Kloppenborg 2000, 102-117).

168 Walle (2010, 62-63) takes note of this fact, although his explanation is not very convincing. Walle thinks that soldiers represent Mithraism and, therefore, a believing centurion does not fit in the story.
} 
ones, it is also a royally virtuous mindset. ${ }^{169}$ The word $\beta \alpha \sigma i \lambda$ เxós does not make it clear that the believing person is a soldier. The official does not metaphorically refer to his power to command minions like the centurion does in the synoptic parallels. All in all, there are no positive military figures in the Gospel of John. As Jesus quite programmatically says, in contrast to the servants of the earthy kingdoms, his followers do not fight. In this, then, there is something akin to modern pacifism. ${ }^{170}$ It is thus difficult to imagine a soldier in a Johannine community.

\subsubsection{The Gospel of Peter}

The Gospel of Peter reflects an interesting development from the canonical gospel tradition. ${ }^{171}$ While Luke is somewhat obscure about whether soldiers or the crowd crucified Jesus, the Gospel of Peter is clear: the crowd did it. Soldiers are not even mentioned in the crucifixion scene, nor before that. For example, the crowd mocks Jesus. The author's tendency is to put the blame on the Jews, while Pilate's role is diminished. ${ }^{172}$ This general tendency is mirrored in the representation of soldiers, who appear only after Jesus is brought to the tomb; the Jewish elders ask soldiers to guard the grave so that the disciples will not steal his body and present a claim of resurrection (Gos. Pet. 8.30). The story is a variant of Matthew's version, but the role of the military is quite different here than in the Matthean version, where soldiers are bribed and liars. Paul Foster claims rightly:

While a Roman presence has been removed from the previous scenes involving the torture and execution of Jesus, it is now required as a reliable witness to the veracity of the resurrection. For this reason the author has the Jewish leaders beseech the impartial Pilate to provide the soldiers, who in narratival terms will perform the more significant role of reliable witnesses. ${ }^{173}$

169 Wegner 1985, 57-6o; Dunderberg 2014, 281, 289-292.

170 "Pacifism" is surely a somewhat anachronistic expression, as John's view does not necessarily presuppose nonviolence, as modern pacifism usually does. Jesus violently expels people from the temple (John 2:13-15).

171 Some, like Crossan (1988), have claimed that the Gospel of Peter transmits an early tradition which is independent of the canonical gospels. Foster (2010, 119-147; see Augustin 2015, 57-109) argues convincingly that the Gospel of Peter is dependent on the synoptic gospels (possibly also on the Gospel of John) and that the unparalleled sections in the Gospel of Peter are due to the author's own creativity. The gospel has been preserved only as a fragment containing the trial, execution, and resurrection of Jesus.

172 Räisänen 2010, 272.

173 Foster 2010, 374. 
This favorable view of soldiers is probably the reason why the Gospel of Peter tells not only of rank-and-file soldiers at the tomb, but also their leader, a centurion called Petronius (Gos. Pet. 8.31). ${ }^{174}$ As I have repeatedly noted, centurions had quite a good reputation. A centurion at the tomb gives reliability to the witness of the soldiers. Against the canonical versions, soldiers are active in rolling the stone into its place at the mouth of the tomb (Gos. Pet. 8.32). Foster sees in this detail "the author's validation of the placement of the body in the tomb prior to the miraculous resurrection."175 The author informs that the soldiers guarded it in an orderly manner in pairs, thereby proving the impossibility of a theft. ${ }^{176}$ During the night, the miracle takes place. The guards see

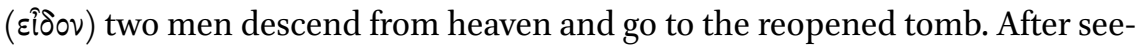

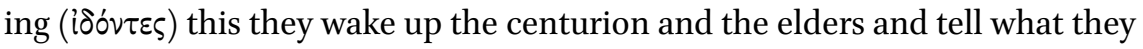

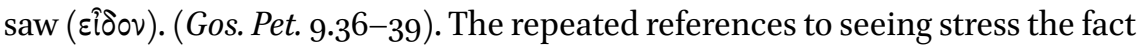
that the soldiers on guard duty really witnessed this miraculous event.

The author's claim that Jewish elders were also guarding the tomb is idiosyncratic. Foster proposes three reasons, asking, "was there a perception that the Romans could be bribed to allow the theft of the body, or that they might be derelict in their duties, or perhaps the narrator simply wanted the Jewish elders present at the resurrection to illustrate how recalcitrant they had become in refusing to accept divine revelation and affirmation of Jesus as God's messiah and son?"177 The first two reasons, bribery and negligence of duties, would be credible when thinking of the general ancient view of rank-and-file soldiers. On the other hand, the narrator likes to present the soldiers as trustworthy witnesses. This is probably why there is also the centurion Petronius, unknown in the canonical tradition, at the tomb. A centurion diminishes doubts about the soldiers. The third reason Foster gives fits well with the author's general tendency to slander the Jewish leaders. Later in the narrative, they prefer to commit a great sin before God over falling into the hands of the people (Gos. Pet. 11.48). The elders did this even though they saw ( $\dot{\rho} \hat{\omega} \sigma(v)$ how Christ came out of the tomb (Gos. Pet. 10.39).

After seeing the miracle, the soldiers, the centurion, and the elders determined to report everything to Pilate. While still thinking to do this they saw an additional miracle, which made the soldiers depart quickly and tell what they

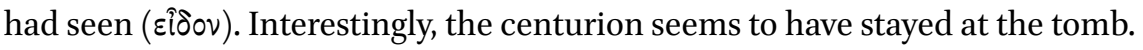

174 Augustin $(2015,138)$ claims that a centurion commanding this small size of a guard is historically suspect.

175 Foster 2010, 382.

176 Foster 2010, 398.

177 Foster 2010, 415 . 


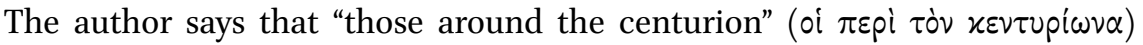
rushed to Pilate and reported what had happened and concluded that "truly this was God's son" (Gos. Pet. 11.43-45). The elders also stayed at the tomb, but later "they all came" to visit Pilate. In the text, "all" refers only to the elders, who prefer sin over being delivered into the hands of the people (Gos. Pet. 11.47-48). ${ }^{178}$ Is the centurion alone at the tomb then? His return is not mentioned. Surely he is assumed to be present when Pilate later commands him and the soldiers. Is he the last one at the tomb, calming remaining after the "distressed" ( $\dot{\alpha} \gamma \omega \nu i \omega \hat{v} \tau \varepsilon \varsigma)$ soldiers have rushed to Pilate and the elders have also arrived there? In this case, he would be the most trustworthy witness of Christ. This is not the only solution. It is possible that Petronius is included in "those around the centurion" and thus he has returned with his soldiers. The Jews ask Pilate to command the centurion and the soldiers not to tell anyone about what happened. Pilate does as the Jews ask and commands the centurion and the soldiers to keep silent (Gos. Pet. 11.49). This is an odd turn of events, as Foster remarks:

With this complete media black-out on reporting the events that occurred, the author does not explain to his audience how he is able to relate this version of events. Is this simply the prerogative of an omniscient narrator, the product of divine revelation, the result of a breaking of silence by one of the observers, or do such questions rob this narrative of the impact it was intended to create for its audience? ${ }^{179}$

Foster leaves the matter open, but I am inclined to see here an intention to say that the soldiers broke the silence. Had this been otherwise, why would the author have placed so much stress on the trustworthiness of the soldiers? The author does not say that the soldiers kept the silence, which is a remarkable difference from Matthew's version. Matthew pointedly says that the soldiers kept silent (Matt 28:15). As the author of the Gospel of Peter probably knew of Matthew's version, it must have been his intentional choice not to follow it here. The figures of the soldiers and the centurion are clearly positive. There is no trace of Matthew's ambiguity around the soldiers, and the positive image of the centurion is similar to the Gospel of Matthew. Petronius' name is surely "due to a fascination for detail in the development of

178 Foster (2010, 448-449) supposes that the soldiers are included.

179 Foster 2010, 455 . 
the tradition, rather than the preservation of a historical detail."180 But naming gives more personal color and makes the figure even more positive in the readers' eyes. The name is a reliably Roman name, which possibly hints that he is a citizen. ${ }^{181} \mathrm{~A}$ centurion is again the most positive military figure-and surely not by accident. The Gospel of Peter just follows the standard imagery of centurions.

\subsection{Conclusions}

The scholarly discussion on soldiers and early Christianity is characterized in the light of modern moral discussions. The sources are often used to defend or oppose Christian participation in the military, as though there were a Christian stance on the issue. In fact, these discussions dismiss the fact that views and practices were diverse among the early Christians. Moreover, all descriptions of soldiers are not meant to be a moral judgement on the question of whether a Christian can serve as a soldier.

I showed that in the gospel material there is an important division between centurions and rank-and-file men. While this division has moral overtones, too, they are not the ones of the modern discussion on Christian ethics. Instead, they reflect the ancient stereotypes of civilized centurions and the brutality of the rank and file. One can only indirectly assume a moral stance on Christian participation in the army. If centurions are acceptable, then the military calling is not questionable in and of itself. This is what one can assume in the case of Mark, Matthew, and—most clearly—Luke. Luke openly states that soldiers must fulfill moral standards: "Do not extort money from anyone by threats or false accusation, and be satisfied with your wages" (Luke 3:14). What comes to the fore here is that soldiers were morally criticized for their violent corruption, not for killing at war, as in the modern debates. Moreover, centurions may have had considerable economic resources, and Christians perhaps used their services. Especially Luke's version of the centurion in Capernaum presents a picture of a wealthy benefactor-surely a proper convert. In general, the gospels speak of soldiers engaged in police work, not at war. The representation of soldiers reflects the views of civilians who encountered soldiers in their everyday life. The soldiers in the synoptic gospels are thus understandable as a part of the social setting. Only Luke seems to have clearer ideological tendencies, as the Roman soldiers contribute to his pro-Roman message, especially in Acts.

180 Foster 2010, 378.

181 Saddington 1996, 2414, 2414 n. 12. 
As is generally known, the Gospel of John differs from the synoptics in many respects; this is also the case in respect to the soldiers represented in it. First, centurions are missing. While Matthew and Luke speak of a centurion in Capernaum, John speaks of a $\beta \alpha \sigma i \lambda$ ixós, which may or may not mean a soldier. John seems to intentionally disregard the military character as soldiers belong to the dark side in his dualism. In the Passion narrative, John even states that earthly rulers use men to fight, but Jesus does not (John 18:36). John proves that there are indeed some antimilitaristic tendencies among the early Christians.

\section{Metaphors, Antimilitarism, and Christian Soldiers}

In this section, I show that the antimilitaristic tendencies pronounced, especially within the literate class. I first look at the military metaphors. Then, I proceed to examine what Christian apologetes and other early Christian theologians have said about soldiers. Their views are well represented in the surviving literature. The views of other Christians must be read through them or on the basis of archaeological evidence. I will show that there were Christian soldiers, despite the antimilitaristic tendency among the theologians.

\subsection{Military Metaphors}

One encounters military issues not only in the literary persons of the gospels. What do military metaphors imply about attitudes toward the military and indirectly about soldiers in Christian communities? John F. Shean refers to the centurion of Capernaum, who presents a military analogy for his authority over those under him and Jesus' authority (Matt 8:8-9; Luke 7:7-8), Paul's military metaphors, and the patristic usage. This leads him to ask what the parlance betrays of the audience:

One can only speculate on the intended audience for such comparisons, but they may reflect the active participation of military personnel in Christian communities for whom such analogies would have had a particular resonance. ${ }^{182}$

182 Shean 2010, 145. Helgeland, Daly, and Burns (1987) claim that there are no military metaphors in the gospels. This is apparently wrong unless we draw a straight line between metaphors and parables and count the centurion's words among the latter. Moreover, there is the parable of a king who wonders if he may engage an enemy in battle (Luke $14: 31-32)$. 
Shean acknowledges that he is only speculating. The key of his assumption is that the analogies of military life "would have had a particular resonance" among soldiers. This sounds intuitively true, but before rushing to conclusions I would like to ask whether the frequency of military metaphors makes sense in the absence of real soldiers among Christians. I will take a look at the use of the metaphors in early Christian writings and then in antiquity in general. After that I will discuss what military metaphors betray about the potential presence of soldiers among the early Christians.

\subsubsection{Military Metaphors in Early Christian Writings}

David J. Williams has helpfully collected military metaphors in the Pauline epistles. ${ }^{183}$ I will neither repeat all these metaphors nor limit my survey to the Pauline material. Instead, I will present examples from this material, add examples outside of the Pauline texts and group the material into three main types. First, there are single military words or expressions used without further elaboration. Second, there are military metaphors for the inner conflict within an individual person. Third, Christian conduct is sometimes presented as military service.

Some single words in early Christian texts originally belong to the military. ${ }^{184}$ For example, in the passage on the wages of sin (Rom 6:23), the word 'wages' $(\dot{\omega} \psi \omega \dot{\omega} \nu \alpha)$ actually means payment or provisions for soldiers. ${ }^{185}$ In Hebrews,

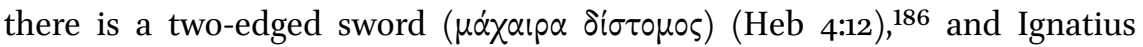
of Antioch says that Christ lifted up a "standard" or a "flag" ( $\sigma \dot{\sigma} \sigma \emptyset \mu \circ v)$ (Ign. Smyrn. 1.2). Ignatius' own zeal wages war $(\pi \circ \lambda \varepsilon \mu \varepsilon \hat{\imath})$ against him (Ign. Trall. 4.2). These are a few examples of single words bearing a military ring. The last example leads to the second type of military metaphors, the description of inner conflict within an individual person. This is quite common in early Christian writings. Ignatius makes his point with one word, but there is a more extended version, for example, in Rom 7:23: "I see in my members another law at war ( $\alpha \nu \tau i \sigma \tau \rho \alpha \tau \varepsilon v o ́ \mu \varepsilon \nu \circ v)$ with the law of my mind, making me captive ( $\alpha i \chi \mu \alpha \lambda \omega \tau i \zeta o v \tau \alpha)$ to the law of sin." Polycarp claims that "every passion wages war ( $\sigma \tau \rho \alpha \varepsilon \dot{\varepsilon} \varepsilon \tau \alpha$ ) against the spirit" (Pol. Phil. 5.3; trans. Ehrman, LCL; cf. also 1 Pet 2:11). The Letter of Peter to Philip, which belongs to the Nag Hammadi

\footnotetext{
183 Williams 1999, 211-244.

184 Of course, it is not always clear which terms can be counted among military metaphors.

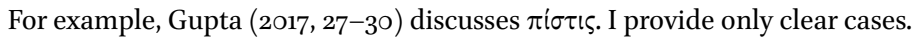

185 Williams 1999, 224.

186 The word $\mu \alpha \dot{\alpha} \chi \alpha$ เp $\alpha$ can also mean a sacrificial knife (Liddell, Scott, and Jones 2011, $\mu \alpha \dot{\alpha} \chi\llcorner\mathrm{p} \alpha$ ).

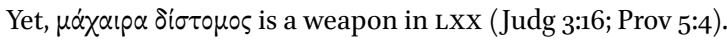


library, also uses a military metaphor for the inner fight. Christian teaching is a way to fight the enemy attacks:

Concerning the fact that you are being detained, it is because you are mine. When you strip yourselves of what is corruptible, you will become luminaries in the midst of mortal people. Concerning the fact that you are to fight the powers, it is because they do not have rest like you, since they do not want you to be saved. The apostles worshiped again and said, "Lord, tell us, how shall we fight against the rulers, since the rulers are over us." A voice called out to them from the appearance and said: "You must fight against them like this, for the rulers fight against the inner person. You must fight against them like this: come together and teach salvation in the world with a promise. And arm yourselves with my Father's power, and express your prayer, and surely the Father will help you by sending me."

NHC VIII,2 137; trans. MEYER

James concludes that the war within the individual Christian is the reason for Christian in-group disputes. He also calls these disputes wars and conflicts. Thus, James develops a two-sided metaphor where the in-personal conflict is the starting point: "Those wars $(\pi \dot{o} \lambda \varepsilon \mu o \iota)$ and conflicts ( $\mu \dot{\alpha} \chi \alpha \iota)$ among you, where do they come from? Do they not come from your cravings that are at

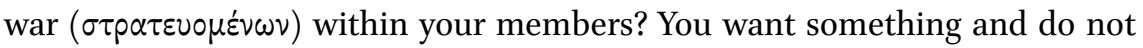
have it, so you commit murder. And you covet something and cannot obtain

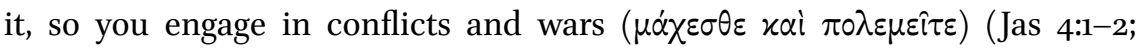
trans. slightly revised)." For James, warfare in Christian daily life is a negative metaphor. Usually it is something positive, as is the case in the Letter of Peter to Philip, cited above.

The positive usage is the third type of military metaphors. The author of 2 Timothy puts it in a way which later became classic:187 "Share in suffering like

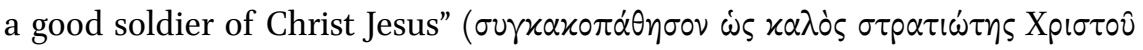
'Inбov) (2 Tim 2:3). This is actually not meant to describe just any Christian, only preachers. The limited usage is already present in the undisputed Pauline

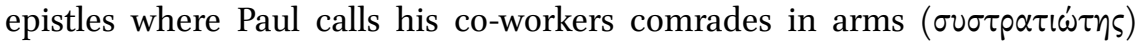
(Phlm 2; Phil 2:25). Early Christian literature also affords examples of all Christians as soldiers. This is openly stated by Clement of Rome when he is discussing the right attitude toward Jesus Christ: "Who then are the enemies (oi $\varepsilon^{\prime} \chi \theta$ poí)? Those who are evil and oppose ( $\left.\dot{\alpha} \nu \tau \tau \alpha \alpha \sigma \sigma o ́ \mu \varepsilon v o l\right)$ his will. And so,

187 See Harnack 1981, 38. 
brothers, with all eagerness let us do battle as soldiers $(\sigma \tau \rho \alpha \tau \varepsilon v \sigma \omega \dot{\omega} \mu \varepsilon \theta \alpha)$ under

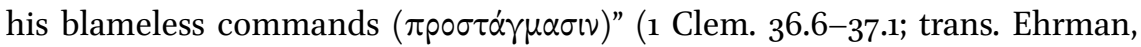
LCL). Clement continues by presenting imperial soldiers as a good example of Christian conduct. The metaphorical Christian army is led by Jesus as the commander-in-chief, Clement says.

In the Gospel of John, Jesus is not the commander but a soldier whose willingness to sacrifice himself is exemplary. Jerome H. Neyrey has presented an illustrative array of classical texts in which the good shepherd repeats the ancient values of a noble warrior who gives his life for others (John 10:11-18) and leaves an example of right conduct. ${ }^{188}$ Jesus also provides an example of heroism with his words: "This is my commandment, that you love one another as I have loved you. No one has greater love than this, to lay down one's life for one's friends. You are my friends if you do what I command you" (John 15:1214). Lengthy military metaphors are found in 2 Corinthians, Ephesians, and Ignatius' epistle to Polycarp. In 2 Corinthians, Paul presents the picture of a victorious battle:

Indeed, we live in the flesh, but we do not wage war according to the flesh, for the weapons of our warfare are not in the flesh, but they have divine power to destroy strongholds. We destroy arguments and every proud obstacle raised up against the knowledge of God, and we take every thought captive to obey Christ. We are ready to punish every disobedience when your obedience is complete.

2 Cor. 10:3-6; trans. revised

Paul presents Christians as an assaulting army that destroys the enemy base and after the battle pacifies the area by punishing every remaining foe. ${ }^{189}$ The aggressive and belligerent tone is quite striking from Paul, who just previously appealed to the recipients of the epistle "by the meekness and gentleness of Christ" (1 Cor 10:1). A similar oddity occurs in Ephesians, where the readiness to proclaim the gospel of peace is joined with a lengthy military metaphor:

Finally, be strong in the Lord and in the strength of his power. Put on the whole armour of God, so that you may be able to stand against the wiles of the devil. For our struggle is not against enemies of blood and flesh, but against the rulers, against the authorities, against the cosmic powers of this present darkness, against the spiritual forces of evil in the

188 Neyrey 2001.

189 Williams 1999, 215-217. 
heavenly places. Therefore, take up the whole armour of God, so that you may be able to withstand on that evil day, and having done everything, to stand firm. Stand, therefore, and fasten the belt of truth around your waist, and put on the breastplate of righteousness. As shoes for your feet put on whatever will make you ready to proclaim the gospel of peace. With all of these, take the shield of faith, with which you will be able to quench all the flaming arrows of the evil one. Take the helmet of salvation, and the sword of the Spirit, which is the word of God.

Eph. 6:10-17

The background of this metaphor is quite surely found in 1 Thessalonians, which is undoubtedly an authentic epistle of Paul, even the oldest one. There Paul exhorts, "But since we belong to the day, let us be sober, and put on the breastplate of faith and love, and for a helmet the hope of salvation" (1 Thess. 5:8). One may note that the pattern illustrates the well-known Pauline triad of faith-hope-love. ${ }^{190}$ Ignatius of Antioch is possibly dependent on the Pauline tradition, but he extends the tradition with concrete Latin words from the Roman military usage of his day:191

Be pleasing to the one in whose army you serve, from whom also you receive your wages. Let none of you be found deserter ( $\delta \varepsilon \sigma \varepsilon \rho \tau \omega \rho)$. Let your baptism remain as your weaponry, your faith as a helmet, your love as a spear, your endurance as a full set of armor. Let your works be a down payment on your wages $(\delta \varepsilon \pi \delta \sigma \tau \tau \alpha)$, that you may receive the back pay $(\ddot{\alpha} \kappa \kappa \varepsilon \pi \tau \alpha)$ you deserve.

Ign. Pol. 6.2; trans. EHRMAN, LCL

Cadoux notes that it was "apparently Paul who introduced this custom of drawing from the military world metaphors and similes illustrative of different aspects of Christian, particularly apostolic, life."192 This is surely right if the criterion is based on the earliest Christian documents on this practice. However, it is up to the reconstruction of the gospel material to determine if this usage goes back to the centurion of Capernaum or to the historical Jesus himself (Luke 14:31-32). ${ }^{193}$ Military metaphors later became increasingly

190 Lohse 1990, 8.

191 For the Latin words and their meaning in the army, see Schoedel 1985, 276. Harnack (1981, 41) explains the presence of these technical terms with the fact that Ignatius wrote his letter during his transportation to Rome under the auspices of soldiers.

192 Cadoux 1919, 161. Cadoux seems to think that Paul is the author of Ephesians.

193 See Hobbs 1995, 271. 
popular among Christians, especially in the West. ${ }^{194}$ Two illustrative examples are the words paganus and sacramentum. The latter originally meant the military oath. ${ }^{195}$ The former could mean a person who lives in the countryside, but it also denoted a civilian in contrast to a soldier. The military meaning seems to be the origin of the term in Christian usage. ${ }^{196}$ Does this fact reflect the active participation of soldiers in the Christian communities, as Shean cautiously assumes? I do not want to hasten to conclusions. The view remains unbalanced as long as the Christian usage is deprived of its ancient context.

\subsubsection{The General Background of Military Metaphors}

Ramsay MacMullen has pointed out that certain military concepts and even slang spread from the army into common usage. ${ }^{197}$ The Latin-based words $\delta \varepsilon \sigma \varepsilon \dot{\rho} \tau \omega \rho$ and $\alpha \varkappa \kappa \kappa \varepsilon \pi \tau \alpha$ in Ignatius' text (Pol. 6.2) clearly belong to this category. However, military metaphors occur already in the pre-Roman Greek. In his article on spiritual warfare, Emonds argues that Plato is the oldest source where a military metaphor is related to human life. ${ }^{198}$ Emonds notes that the metaphor in Apologia became very popular. ${ }^{199}$

This is in truth how it is, fellow Athenians. Wherever someone takes his stand thinking it's the best thing to do, or is posted by his commander, he must remain there, in my opinion, and face the danger without taking into account either death or anything else rather than the prospect of disgrace. So I would have done a dreadful thing, fellow Athenians, if, when the commanders whom you had chosen to lead me gave me orders both in Potidaea and Amphipolis and Delium, on that occasion I remained where they had posted me like anyone else and risked being killed, but when the god commanded, as I thought and assumed, that I must spend my life in philosophy and examining myself and others, I then abandoned my post because I was afraid of dying or some other difficulty. That would have been dreadful and in truth then someone would have justly taken

\footnotetext{
194 Harnack 1981, 52-61.

195 Harnack 1981, 53-55.

196 Harnack 1981, 84,105. Harnack refers to examples in Christian and non-Christian texts, among others Tertullian's De Corona 11.

197 MacMullen 1963, 165-169.

198 Emonds' article was originally published in Heilige Überlieferung. Ausschnitte aus der Geschichte des Mönchtums und des heiligen Kultes. Eine Festgabe zum silbernen Abtsjubiläum des hochwürdigen Herrn Abtes von Maria Laach Dr. theol. et iur. h.c. Ildefonds Herwegen (Münster: Aschendorffsche Verlagsbuchhandlung: 1938), pages 21-5o. I refer to the pages of the 1963 reprint, which appears as an appendix of Harnack's Militia Christi.

199 Emonds 1963, 135.
} 
me to court because I don't believe gods exist, disobeying the oracle and fearing death and thinking I'm wise, though I'm not.

Plato, Apol. 28D-29A; trans. EMLYN-JONES and PREDDY, LCL

Plato is not the first to use this type of metaphor, however. Referring to Cicero (Sen. 73), Emonds states that these kinds of metaphors must have been present in the Pythagorean sources before Plato. ${ }^{200}$ Yet, Plato's words became very influential, as Epictetus shows, for example, in a context where he explicitly refers to Socrates:

You make yourselves ridiculous by thinking that, if your general had stationed me at any post, I ought to hold and maintain it and choose rather to die ten thousand times than to desert it, but if God has stationed us in some place and in some manner of life we ought to desert that.

Epictetus, Disc. 1.9.24; trans. Oldfather, LCL ${ }^{201}$

Emonds shows that the topos appears not only in Epictetus but also in Seneca, Marcus Aurelius, and the writing of De Mundo by an unknown author (usually called Ps.-Aristotle). ${ }^{202}$ The concise form is found in Seneca (Ep. 96.5): "Life is warfare." Marcus Aurelius follows suit (Med. 2.17). What comes to the versions of the military metaphors, Emonds distinguishes two types, the metaphysical or mystical metaphor and the ethical metaphor. In Plato's metaphors he sees the metaphysical version, where Socrates understands himself in a certain relationship with God. In Seneca's texts he sees a more ethical aspect, following Stoic lines. ${ }^{203} \mathrm{I}$ am not sure that Stoicism put less weight on the relationship with God. At least Epictetus and Cleanthes prove the opposite. ${ }^{204}$ This also goes for the military metaphor, as proved by Epictetus' passage cited above.

200 Emonds 1963, 138. Moreover, one should bear in mind that Heraclitus spoke of natural phenomena in terms of war. See fragment 80 , and possibly also 53, as explained by Kirk (1962, 238-249).

201 For similar references to this section of Plato's Apologia, see Epictetus, Disc. 3.1.19-20; 3.24.99.

202 Emonds 1963, 142-162. Emonds fails to show that the military metaphor was present in early Stoicism, though he thinks that it must have been there. The only reference he gives is Cleanthes' prayer transmitted by Epictetus (Ench. 53), but it is hardly clear that a military metaphor was really intended. Yet, it is without question that in New Testament times there were military metaphors in non-Christian sources.

203 Emonds 1963, 136-137, 148-149.

204 On Stoic theology in general, see Algra 2003; for Cleanthes' religion, see Thom 2005; for Epictetus' religion, see Long 2002, 142-179. 
One can say fairly that as concerns the religious dimension in general, there is no lack of ancient military metaphors. In this sense, the early Christian usage is similar. There are analogies for all three types of military metaphors in Christian texts. First, there are single military words with a metaphorical meaning (e.g., Epictetus, Disc. 3.22.18). Regarding the second type of military metaphors, the conflict within an individual, Aristotle speaks of it with expressions closely reminiscent of Rom. 7:23. According to Aristotle, the human soul seems "to contain another element beside that of rational principle, which

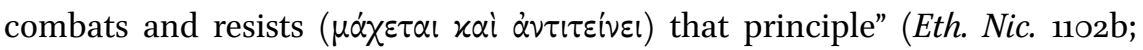
trans. Rackham, LCL; cf. Plato, Leg. 626e). James claimed that the inner conflict in individual Christians also causes "wars" and "conflicts" ( $\pi \dot{\lambda} \lambda \varepsilon \mu 0 \mathrm{l}, \mu \dot{\alpha} \chi \alpha \iota)$ between Christians who covet something and do not get it without violence. This is an old theme. Plato writes: "For nothing causes us wars, revolts and

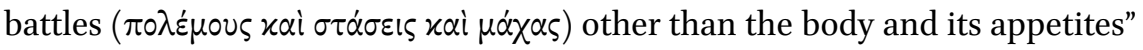
(Phaed. 66c; trans. Emlyn-Jones and Preddy, LCL). This is echoed by Epictetus:

For it is my nature to look out for my own interests. If it is in my interest to have a farm, it is in my interest to take it away from my neighbour; if it is in my interest to have a cloak, it is in my interest also to steal it from a bath. This is the source of wars, uprisings, tyrannies, and plots ( $\pi \dot{\partial} \lambda \varepsilon \mu$,

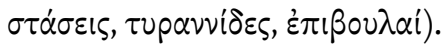

Epictetus, Disc. 1.22.14; trans. Oldfather, LCL revised

Plato and Epictetus speak of wars and uprisings in relation to literary meaning. However, their reasoning is close to that which James metaphorizes when speaking of Christian in-group disputes as wars.

The third type of military metaphors comprises the one where Christian conduct is described as warfare. A good parallel is in Plato's Apologia cited above. Clement (1 Clem. 36.6-37.1) emphasizes the orderly conduct of Christian life with a comparison to order in the army. Clement's words have a parallel in De Mundo, whose unknown author (called Ps.-Aristotle) compares the orderly processes of the universe (cf. 1. Clem. 20) to those of an army.

The process is very like what happens, particularly at moments in a war, when the trumpet gives a signal in a military camp; then each man hears the sound, and one picks up his shield, another puts on his breastplate, and a third his greaves, helmet or belt; one harnesses his horse, one mounts his chariot, one passes on the watchword; the companycommander goes at once to his company, the brigadier to his brigade, the cavalryman to his squadron, and the infantryman runs to his own station; 
all is stirred by a single trumpeter to a flurry of motion according to the orders of the supreme commander.

Ps.-Aristotle, Mund. 399 B; trans. FURLEY, LCL

De Mundo lacks the ethical intention so clear in 1 Clement, but as we have seen in the texts of other ancient authors, the military metaphor is easily extended in this direction. The form of catalog also reminds one of the metaphor in Paul's epistle to the Ephesians though there is no detailed metaphorical breakdown of the soldiers' equipment. Catalogs of the equipment that soldiers used can be found, for example, in Homer's Iliad $3 \cdot 328-339 .{ }^{205}$ I am not aware of any allegorical interpretation of these (or similar) Homeric verses, but if there are any, they would provide a good parallel to Ephesians. Ephesians is also recalled in Musonius Rufus' comparison between clothes and the armor ( $\pi \alpha v 0 \pi \lambda i \alpha)$; just as one uses weapons $(\ddot{\sigma} \pi \lambda \alpha)$, which protect the bearer, one should also wear clothes suited for the protection of the body and not for display (Musonius Rufus 19). ${ }^{206}$ Abraham J. Malherbe notes that some Cynics understood their rough cloaks as their armaments. ${ }^{207}$ There are also clear models for Christian writings in the Jewish scriptures:

He put on righteousness like a breastplate, and a helmet of salvation on his head;

he put on garments of vengeance for clothing, and wrapped himself in fury as in a mantle.

Isa 59:17

Here, as in Wisdom of Solomon 5:17-40, it is God who puts on the military equipment. This imagery is transferred to the Christians in Ephesians. ${ }^{208}$ Thus, military metaphors were known to Christians from scripture and from the general Greco-Roman discourse. All three types of military metaphors can

205 "But goodly Alexander did on about his shoulders his beautiful armour, even he, the lord of fair-haired Helen. The greaves first he set about his legs; beautiful they were, and fitted with silver ankle-pieces; next he did on about his chest the corselet of his brother Lycaon, and fitted it to himself. And about his shoulders he cast his silver-studded sword of bronze, and thereafter his shield great and sturdy; and upon his mighty head he set a well-wrought helmet with horse-hair crest-and terribly did the plume nod from above - and he took a valorous spear, that fitted his grasp. And in the self-same manner warlike Menelaus did on his battle-gear" (trans. Murray, LCL).

206 Lutz 1957, 120, lines 21-25.

207 Malherbe 1983, 157.

208 Best 1998, 587. 
be found in classical texts. In the Christian usage, the metaphors with their theological implications are just "christened." The military element does not substantially differ from the non-Christian texts. This fact frames our approach anew. One cannot straightforwardly ask whether the Christian use of the military metaphors speaks of Christian soldiers. Instead, one has to ask whether there is a correlation between the use of military metaphors and some attitude toward soldiers.

2.1.3 Do Military Metaphors Speak of Real Soldiers?

In Plato's case, there is a positive correlation between the military theme of the metaphor and actual military life. In the text, the metaphor is developed in relation to Socrates' dutiful service in earlier campaigns. As Epictetus' echo of this metaphor shows, the correlation is not always so clear. In the passage cited above, he compares any social position in life (given by God) to the post of a soldier (commanded by a general). ${ }^{209}$ One of those actual social positions can be that of a soldier (Disc. 3.24.99). God put Agamemnon in command, as he was "able to lead the host against Ilium" (Disc. 3.22.7; trans. Oldfather, LCL). Socrates is a great moral example, which includes his military service (Disc. 3.24.61; 4.1.159-160). Despite these positive sayings on soldiers, there is no clear correlation between the use of the military metaphor and a positive attitude toward military things. Wars break out due to philosophical lapses (Disc. 1.22.14; 2.22.22), as was seemingly the case in the Trojan War. In a fictional discussion with Agamemnon, Epictetus points out that there is no reason to attack Troy (Disc. 3.22.36-37). At last, philosophical training leads to the Stoic indifference toward everything, including wars and armies:

How, then, is a citadel destroyed? Not by iron, nor by fire, but by judgements. For if we capture the citadel in the city, have we captured the citadel of fever also, have we captured that of pretty wenches also, in a word, the acropolis within us, and have we cast out the tyrants within us, whom we have lording it over each of us every day, sometimes the same tyrants, and sometimes others? But here is where we must begin, and it is from this side that we must seize the acropolis and cast out the tyrants; we must yield up the paltry body, its members, the faculties, property, reputation, offices, honours, children, brothers, friends-count all these things as alien to us. And if the tyrants be thrown out of the spot, why should I any longer raze the fortifications of the citadel, on my

209 On Epictetus' thoughts about social positions, see Huttunen 2009, 24-26. 
own account, at least? For what harm does it do me by standing? Why should I go on and throw out the tyrant's bodyguard? For where do I feel them? Their rods, their spears, and their swords they are directing against others.

Disc. 4.1.86-88; trans. Oldfather, LCL

Abraham Malherbe has shown that this Epictetan metaphor has a long tradition, beginning with Antisthenes the Cynic. ${ }^{210}$ In Epictetus' version, concrete military things like fortifications turn out to be adiaphora. Actual warfare is meaningless to the one whose judgments are right. It is worth comparing Epictetus' thought with 2 Corinthians 10:3-4, which closely resembles the Antishenian tradition, as Malherbe demonstrates. Paul points out that "we do not wage war fleshly; for the weapons of our warfare are not fleshly."211 Christian warfare is warfare in a metaphorical meaning without any explicit connection to actual military operations. There is not one word about actual warfare. $^{212}$ The metaphorical meaning of warfare is repeated in Ephesians: "Our struggle is not against enemies of blood and flesh, but against the rulers, against the authorities, against the cosmic powers of this present darkness, against the spiritual forces of evil in the heavenly places" (Eph. 6:11). The list of soldiers' equipment is explained with their spiritual equivalents, so that the reader cannot miss the spiritual nature of the warfare. This kind of metaphorical usage is already found in Isaiah (Isa 11:4-5; 59:17), but the exact relationship between Ephesians and Isaiah is not clear. ${ }^{213}$

These Pauline words in 2 Corinthians and Ephesians may sound pacifistic, ${ }^{214}$ which they are not. The words "we do not wage war fleshly" (2 Cor. 10:3) mean that the war Paul is speaking of is not a war in the ordinary sense: "we"referring to all Christians - are waging special kind of war. What one should think about soldiers waging ordinary wars is left unspoken. It is surely an overstatement to see here a claim against ordinary wars. It is only underlined that the war under discussion has an unusual meaning. A similar point can be made in Ephesians. "Our struggle" underlines the anomalous meaning of war

\footnotetext{
210 Malherbe 1983.

211 The translation is a modification of the NRSV. For some reason or other, the NRSV translates this passage as saying that the weapons are not merely carnal, as if there were also carnal weapons.

212 I cannot say if warfare is indifferent to Paul in this passage. He was acquainted with the Stoic idea of adiaphora (Huttunen 2009, 26-31).

213 Lincoln 1990, 436. Asher (2014) helpfully illustrates the cultural background of missiles or arrows being attributed to the devil.

214 For this reason, it is no surprise that Cadoux $(1919,162-163)$ noted them.
} 
in Christian life. In other words, it does not deal with struggle in the ordinary sense. One must add that promoting "the gospel of peace" by military means (Eph. 6:15) is not a contradiction in terms, as the imperial ideology of the Pax Romana was grounded in the Roman army securing the peace. ${ }^{215}$ This ideology is turned toward Christian use without any indication of the attitude toward the Empire or its army.

2 Corinthians 10:3-4 and Ephesians 6:10-17 lack any connection to ordinary warfare. Thus, they do not say anything of actual soldiers. As the military metaphors in the Christian texts clearly belong to the common usage in antiquity, they do not create any grounds for a hypothesis regarding Christian soldiers. It is noteworthy that Ignatius of Antioch can both use a military metaphor (Ign. Pol. 6:2) in the positive sense and paint actual soldiers in a negative light:

From Syria to Rome I have been fighting the wild beasts, through land and sea, night and day, bound to ten leopards, which is a company of soldiers, who become worse when treated well. But I am becoming more of a disciple by their mistreatment.

Ign. Rom. 5.1; trans. EHRMAN, LCL

The military metaphor is woven even into this saying. The expression "From Syria to Rome ... through land and sea, night and day" resonates with the imperial propaganda by which an emperor or army leader would relate his military achievements in the campaigns. ${ }^{216}$ At the same time, Ignatius' view of soldiers is clearly negative. The passage does nothing more than state the ancient perception, however: rank-and-file soldiers are mean. ${ }^{217} \mathrm{His}$ military metaphors do not tell anything of soldiers in Christian communities. The common discourse provided these metaphors, which Christians could use for their own purposes. Comparing the domestic and the military metaphors, Raymond Hobbs notes that the latter emphasize more the outer and visible aspect of a person's behavior. There is also a strong emphasis on boundary control and heroic suffering in the military metaphors. Hobbs concludes that their use "reflects a community which sees itself as a community under threat from human and superhuman powers." ${ }^{218}$ Hobbs' claim fits well with the defensive character of soldiers' equipment in 1 Thessalonians 5:8 and Ephesians 6:10-17. Especially

\footnotetext{
215 See what I said above about the eippvoroiós (Matt. 5:4).

216 Schoedel $1985,178$.

217 Cadoux (1919, 92 n. 2) understands this as he explicates Ignatius' words with Edward Gibbon's statement: "The common soldiers, like the mercenary troops of modern Europe, were drawn from the meanest, and very frequently from the most profligate, of mankind."

218 Hobbs 1995, 266-268, 270.
} 
in the latter text, the Christians are under an attack. In 2 Corinthians 10:3-4, however, the reader encounters a more offensive and triumphant metaphor, where the enemy is under threat of annihilation. Thus, the military metaphors do not always speak of a community under threat, but rather of a situation of struggle in general. 219

Military metaphors later became quite common in Western Christianity. Harnack states that in the third century, Latin Christianity is "filled with images of military service, military discipline, and battle. One may flatly state that this schema and these images are the most frequent of all."220 This may suggest a greater influence of the army within the Church, but there is also another option: the values of military metaphors described by Hobbs were intensified by the Church. These two options are not mutually exclusive, and the intensified use of the metaphors in early Latin Christianity is an interesting phenomenon which I will examine again in Tertullian's case, treated below. At this point, it is enough to state that the sheer existence of some military metaphors in a text does not testify to the existence of Christian soldiers. The investigation of the metaphors does not merely lead to a dead end. It is perhaps enough to say that military themes are not avoided by the early Christian authors we have examined. Military life was but one part of the experienced world that provided illustrative material for Christian rhetoric. Scholars have not always avoided the temptation to read more into it. As we saw at the beginning of this chapter, Shean speculates about the military audience. In contrast, scholars with pacifist leanings are eager to read the military metaphors as implicating an exclusion of military life in the normal sense. The spiritual point of these metaphors would then exclude any actual military invovement. ${ }^{21}$ This is far-fetched, as J.J. O'Rourke aptly notes:

[T] he use of a figure of speech merely shows the use of the figure of speech; one would scarcely take the comparison of the coming day of the Lord with a nocturnal thief (Mt 24,43; 1 Th 5,2), or "Behold I come as a thief" (Ap 16,15), as an indication of the early Church's view of thieves. ${ }^{22}$

\footnotetext{
219 Lohse $(1990,13)$ claims that the battle is just the defensive matter of adherence to the victory that Christ has already won, in contrast to the Qumran community, which looked forward to the future victory. Yet, even in the metaphorical sphere, we encounter Christians on the offensive, not to mention in their visions of the future visions (for example, Revelation).

220 Harnack 1981, 6o.

221 See, e.g., Gabris 1977, 228-229.

222 O'Rourke 1970, 235.
} 
In some cases, however, one can sense concrete dimensions. First, there is sometimes a vague boundary between a metaphor and apocalyptic warfare. In Ephesians 6, the war is waged not by real weapons but by spiritual weapons. Nevertheless, there is a real war going on-not in a mundane sense but a celestial one:223 "For our struggle is not against enemies of blood and flesh, but against the rulers, against the authorities, against the cosmic powers of this present darkness, against the spiritual forces of evil in the heavenly places" (Eph. 6:12). There is also a certain future day given for the battle: "the whole armor of God" should be taken in order to withstand "that evil day" (Eph. 6:13). If the author means the final day of the eschatological tribulations, he means that Christians will really wage war in the end times. Yet, the metaphorical meaning of "gearing up" with military equipment makes clear that it is not a question of war in the normal sense. In this way, the war in Ephesians differs from the apocalyptic wars described in the Christian and Jewish sources. ${ }^{224}$ It is also possible to see the expression "that evil day" as a reference to the whole present age, possibly with an idea of "a climatic evil day, when resistance will be especially necessary."225 This turns our perspective back to the idea of continuous Christian conduct presented as warfare against cosmic forces.

Cosmic military powers are known in the early stage of the Hebrew Bible (cf. Gen 32:2-3), but mostly they are combined with apocalyptic visions (cf. 2 Macc 3:24-26; 1QM XII). There are similar visions in Christian sources (cf. Rev 12:7), where Christ can be a commander leading the troops to a victory in the final battle (Rev 19:11-21). In the Gospel of Matthew, Jesus refers to celestial legions that are ready to fight when necessary (Matt 27:53). ${ }^{226}$ The visions tell of an army which prevails over all others and, thus, reduces the significance of any terrestrial forces. These apocalyptic armies wage actual war, though differently and more effectively than mundane ones. In this sense, Christian texts do speak of actual warfare. There is also one case where the metaphor carries a positive attitude toward the Roman army. Clement of Rome presents the Roman army as an example for Christian life within the congregation. However, the way Clement describes the Roman army betrays more of a positive attitude. Clement states, "Consider those who soldier under our own leaders” (1 Clem. 37.1; trans. Ehrman, LCL).

\footnotetext{
223 Harnack 1981, 36.

224 Lincoln 1990, 438.

225 Lincoln 1990, 446.

226 Jesus' words "Whoever takes the sword will perish by the sword" in the previous verse is often used to promote pacifism. This is difficult to defend, however, in the context where angelic legions are legitimately clad in armor.
} 
Harnack notes Clement's discourse using "our": "The spokesman of the Roman congregation looks upon the Roman army with satisfaction and pride. Can he regard an army whose discipline and obedience he praises as in every respect the camp of the devil? I think not."227 Louis J. Swift goes further, stating that without speaking of Christian participation in war, Clement's stance is difficult to reconcile with pacifism. He continues: "The fact that the author is not at all embarrassed by such imagery very likely indicates that the problem of a Christian's serving in the army was not an issue for him."228 This is a sole exception among the early Christian metaphors. Otherwise the metaphors do not tell about the attitudes toward the soldiers. The Christian authors used the metaphor as their contemporaries did. But if the case is this, we can conclude that the views of Christian authors did not greatly differ from those of their contemporaries. As I have shown, Epictetus seemed to be slightly negative toward warfare and soldiering without being an outspoken pacifist in the modern sense. Indeed, he shared the common literate view, which is clearly visible among the apologists and early Christian theologians, as I argue below.

The Antimilitarism of Christian Intellectuals and the Christian in the Ranks of the Roman Army

\subsubsection{Philosophical Disgust toward Wars and Armies}

In his The Second Church, Ramsay MacMullen speaks of a divide between elite Christians and the common believers, whose life can be reconstructed mainly through archeology. ${ }^{229}$ The literary evidence comes from the elite, reflecting their views. If the Christian populace is represented at all, it happens on the elite's terms. I will show that the divide between the theological elite and the populace makes understandable why there were both strong antimilitarists and soldiers among the early Christians. Actually, this divide was common in contemporary Roman culture. It is exemplified in a case reported by Tacitus, who tells how Vitellius's army halted Vespasian' troops in a Roman suburb. After successful defense, Vitellius sent several delegations to persuade the enemy that a peace agreement would be better than a fight. Musonius Rufus, a prominent Stoic philosopher who belonged to one of these, ${ }^{230}$ found that his ideas were strongly rejected by Vespasian's men.

227 Harnack 1981, 7 O.

228 Swift 1983, 33.

229 MacMullen 2009.

230 On Musonius, see, e.g., Thorsteinsson 2010, 40-54. 
Musonius Rufus had joined these delegates. He was a member of the equestrian order, a man devoted to the study of philosophy and in particular to the Stoic doctrine. Making his way among the companies, he began to warn those in arms, discoursing on the blessings of peace and the dangers of war. Many were moved to ridicule by his words, more were bored; and there were some ready to jostle him about and to trample on him, if he had not listened to the warnings of the quieter soldiers and the threats of others and give up his untimely moralizing.

Tacitus, Hist. 3.81; trans. MOORE, LCL

The troops were frenzied, heightening the dissonance between the soldiers and the philosopher. Still, I would claim that the situation betrays the divide between the moral views of the philosophical elite and the populace. Musonius' antimilitarism won little understanding. This divide is important to acknowledge in order to understand why there were both soldiers and strong antimilitarists among the early Christians. To be sure, there were also upper-class Christian authors (just think of Luke!) who saw nothing wrong with the military. Yet, as a generalization, the divide provides an explanation for the presence of soldiers, despite certain antimilitaristic traits among the early Christians. I will first examine how the philosophical elite viewed wars and soldiers. Then I will turn to examine the early Christian theologians, who appear to have been negative or hesitant in relation to military issues. Next, I will examine both the literary and archeological evidence of Christian soldiers. At the end of this chapter, I concentrate on Tertullian, who, despite his antimilitaristic views, openly discusses Christian participation in the army.

In ancient Rome, the upper-class and literate view on soldiers was somewhat negative. ${ }^{231}$ In the New Comedy, which flourished before the Empire but was still known during it (see, e.g., Marcus Aurelius, Med. 11.6), "the stock character soldier of comedy is usually portrayed as swaggering and boastful. His masculinity goes to excess, and he does not tend to learn by experience."232 Alexander Kyrychenko notes that this negative view of the soldiers is a literary topos. $^{233}$ There were exceptions to this general view. Some within the literate elite did not share the negative picture of soldiers. Caesar's works are examples of positive attitudes toward the military. Yet, the literary topoi tell of the general atmosphere. Especially the philosophical elite felt some kind of disgust toward the military. Harry Sidebottom argues that their "attitudes to soldiers

231 Campbell 2002, 33 .

232 Pierce 1998, 139. I thank Marika Rauhala for drawing my attention to this matter.

233 Kyrychenko 2014, 89-9o. 
appear to have usually been a mixture of alienation, contempt, and antipathy." He illustrates his point with examples:

Philosophers' dislike of soldiers found expression in unflattering comparisons. Soldiers were like sheepdogs, which were renowned for their viciousness. They were compared to sailors, and the bad company kept on ships was proverbial. They were likened to pedagogues, and they were generally thought of as being of such low status that they were like hired labour for the grape harvest. Serving on a campaign was said to be like being a convict.

Epict. 4.1.39; cf. 3.24.29234

There was even some philosophical "flirtation with pacifism,"235 but not without a certain degree of ambiguity. Especially the wars in the remote past could be viewed positively and the fulfilling of military duty could be viewed as a good thing. ${ }^{236}$ For example, Epictetus praises Spartans who died fighting in Thermopylae (Disc. 2.20.26), ${ }^{237}$ and he sees it as a duty to serve as a soldier (e.g., Disc. 3.22.7; 3.24.61, 99; 4.1.16o). This last view contains a certain ethical admiration of military discipline-something which legions honored as the divine Disciplina. ${ }^{238}$ Even if certain military features are admired, they are mostly presented as a singular point of comparison. The point of these comparisons or metaphors is to exhort the civilian audience to lead a better life. Military life is not the point but just a vehicle for moral exhortation in civil life. Epictetus' exemplary soldiers are mostly persons of mythology or the remote past. In the abovementioned passages, the dutiful soldier is Socrates or a person in Homer's Iliad. In the remote past, there were some brave battles, like those waged by the stout-hearted Spartans, who died fighting for freedom in Thermopylae (Disc. 2.20.26). ${ }^{239}$

These brave soldiers were actually figures of literary and cultural traditions, not contemporary or real soldiers. Military heroes of recent history or contemporary life were lacking. Epictetus presents a former slave, who suffered through three campaigns in order to get a higher office, only to find himself "in the handsomest and sleekest slavery" (Disc. 4.1.39-40; trans. Oldfather, LCL). There was nothing brave about military life here, as the ex-slave was

\footnotetext{
234 Sidebottom 1993, 253.

235 Sidebottom 1993, 262.

236 Sidebottom 1993, 254-255.

237 Huttunen 2009, 85-86.

238 Other military virtues honored as deities were Honos, Virtus, and Pietas (Helgeland, Daly, and Burns 1981, 48).

239 For this abnormal estimation of warfare in Epictetus, see Huttunen 2009, 85-86.
} 
emotionally dependent on external things; according to Epictetus, his social prestige belonged to indifferent things, ${ }^{240}$ and his suffering in campaigns was futile. Epictetus' philosophical view of war contains a strong trace of negativity: wars are due to a lack of philosophical knowledge (e.g., Disc. 1.22.14; $2.22 .22 ; 3.22 .32-37$ ). This philosophical disgust toward wars also seemed to be Musonius' perspective when he tried to inspire pacifism in Vespasian's troops.

Epictetus' admirer Emperor Marcus Aurelius could not avoid wars. This created an ethical dualism, which he himself noted in his Meditations. He lamented that several experiences, including war among others, obliterate all the holy principles of philosophy (Med. 10.9). After this notion, he continues with an example using self-irony:

A spider prides itself on capturing a fly; one man on catching a hare, another on netting a sprat, another on taking wild boars, another bears, another Sarmatians. Are not these brigands, if thou test their principles?

MARCUS AURELIUS, Med. 10.10; trans. HAINES, LCL

The self-irony is found in the Sarmatians mentioned here. Marcus Aurelius led the Roman army in 170 against northern enemies, among others the Sarmatians. ${ }^{241}$ He assumed the title Sarmaticus, the conqueror of the Sarmatians, in the year $175 .{ }^{242}$ The column erected to the memory of the Emperor and the triumphal arch depict prisoners of war that his army captured. ${ }^{243}$ The divide between philosophers and other people is thus embodied in the Emperor's person. Most other philosophers could avoid an encounter with the necessities of the political life and thereby maintain their antimilitaristic views in an uncompromised manner. Sidebottom notes: "The perception that warfare did not impinge directly on the ordinary lives of the majority of the inhabitants of the empire, coupled with tenets of Stoic philosophy, led to what can be seen as significant omissions in the philosophers' stated views on warfare."244 Early Christian theologians like Aristides, Justin the Martyr, Athenagoras, Irenaeus, and Clement of Alexandria belonged to the intellectual elite with a philosophical education. It is no surprise that they represent the same philosophical attitude in the christened form.

\footnotetext{
240 Huttunen 2009, 20-26.

241 On these wars, see Birley 1987, 159-183. Birley calls Sarmatians "Jazyges."

242 Birley 1987, 189; Rutherford 1989, 2-3.

243 See the picture on the opening page of Haines' edition of the Meditations and the pictures in Ferris 2009, 121-126.

244 Sidebottom 1993, 258.
} 


\subsubsection{Theologians of the Early Church}

Aristides of Athens, who lived in the first decades of the 2nd century, writes in passing that the immoral tales of Greek gods misled people toward several disasters, including wars: "So that from these misguided practices it has been the lot of mankind to have frequent wars and slaughters and bitter captivities" (Aristides of Athens, Apologia 8; trans. ANF 9.269). War belongs to the miseries of the world, yet Aristides provides no further elaboration on the theme. Actually, one cannot know what exactly he thought about war and military service. The theme seems distant to him. His criticism of polytheism and the traditional tales of gods is old, as it is already found in Xenophanes (6th and 5 th centuries BCE). ${ }^{245}$ Thus, Aristides just modifies an ancient philosophical tradition to Christian use.

Justin Martyr (ca. 100-165) is sometimes presented as refusing military service. ${ }^{246}$ He wrote that the fallen angels sowed all kinds of vices among humankind: "murders, wars ( $\pi \circ \lambda \varepsilon \dot{\mu} \mu \nu \varsigma)$, adulteries, intemperate deeds" (2. Apol. 5.4; trans. ANF 1:190). One may explain war as a metaphor for the personal strivings between individuals. This explanation, however, does not rule out war in the literal sense. Justin is namely speaking of any kind of conflict, as he says that the fallen angels and the demons did these things "to men, and women, and cities, and nations" (2. Apol. 5.5; trans. ANF 1:190). Thus, wars are the large-scale version of personal striving. Here Justin belongs to the Greek philosophical tradition. For example, both Plato and Epictetus saw personal and collective strivings in the same continuum, although they did not speak of fallen angels or demons. ${ }^{247}$ However, middle Platonists knew different kinds of demons, both good and evil. Apuleius claims that there are demons who are souls that have left their bodies. The souls who have sinned in the body are bad demons, creating all kinds of havoc (De deo Socr. 153). ${ }^{248}$ Plutarch describes the activities of certain evil demons as follows:

But as Heracles laid siege to Oechalia for the sake of a maiden, so pow-

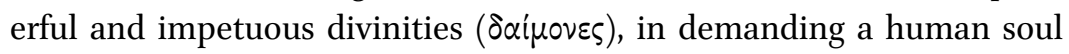
which is incarnate within a mortal body, bring pestilences and failures of

245 On Xenophanes, see, e.g., Lesher 1992.

246 Cadoux 1919. 103; Bainton 1946, 196; Sider 2012, 23.

247 See Plato, Phaed. 66c and Epictetus, Disc. 1.22.14 (cited above).

248 Dillon 1996, 319. 
crops upon States and stir up wars and civil discords, until they succeed in obtaining what they desire.

Plutarch, Moralia 417 D-E; trans. BABBITT, LCL ${ }^{249}$

Justin gives a Christian character to the generally known philosophical view. The Christian side of his argumentation is the reference to the Book of Isaiah, which he reads as a prophecy of the Christian mission.

For out of Zion shall go forth instruction, / and the word of the Lord from Jerusalem. / He shall judge between the nations, / and shall arbitrate for many peoples; / they shall beat their swords into ploughshares, / and their spears into pruning-hooks; / nation shall not lift up sword against nation, / neither shall they learn war any more.

Isa $2: 3-4$

Justin concludes that the prophecy was fulfilled when God sent the disciples from Jerusalem. The result is that "we who formerly used to murder one another do not only now refrain from making war upon our enemies (ov $\pi \circ \lambda \varepsilon \mu \circ \vartheta \hat{\mu} \varepsilon \nu$

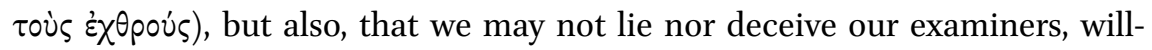
ingly die confessing Christ" (1. Apol. 39.3; trans. ANF 1:175-176). Again, "making war" may be a metaphor for personal strivings, and here the metaphorical sense seems to be in the foreground. Justin continues by comparing Christian readiness for martyrdom to soldiers being ready to die. The metaphorical sense seems to be close also in Justin's other reference to the same prophecy: "[W]e who were filled with war, and mutual slaughter, and every wickedness, have each through the whole earth changed our warlike weapons, - our swords into ploughshares, and our spears into implements of tillage,- - and we cultivate piety, righteousness, philanthropy, faith, and hope" (Dial. 110.3: trans. $A N F$ 1:254). Justin metaphorically explains the agricultural words as referring to piety and other spiritual virtues. Thus, it is also natural to understand "war" metaphorically without totally excluding the literal sense. As shown above, in Second Apology 5.4-5, personal and national enmity are the same thing, albeit on different scales.

Beside his peaceful message, Justin also maintains that the destruction of Jerusalem in the Bar Kokhba revolt was a righteous punishment (Dial. 108.1, 3; 110.6). The Roman rulers and the Roman army seem to be a divine instrument against the unrepentant Jews. Similarly, Luke maintains that the Romans

249 In this matter, Plutarch seems to be dependent on Xenocrates, a philosopher of the Old Academy in the fourth century вC (Dillon 1996, 32). 
punished Jerusalem in the Jewish war (Luke 19:41-44). This thinking reflects the Deuteronomistic theology. In the Deuteronomistic history, the Babylonians put divine punishment into effect. This does not entail any positive statement about Babylonians, however. Thus, the statements about Romans punishing Jews are vague, and they can be interpreted in different ways. Justin grants recognition to the rulers and expects that they will punish wrongdoers (1 Apol. 17; 2 Apol. 9). He requires the emperor to punish even the Christian heretics (1 Apol. 16.14). There is a parallel in Epictetus' thought. Although Epictetus is mainly against the violent use of power, he admits in passing that rulers rightly punish wrongdoers. Yet, even in this case Epictetus points out that rational means are much better for ruling (Disc. 3.22.94). ${ }^{250}$

Justin and Epictetus did not totally deny the violent use of power. As we saw above, the main line of their thought, however, took another direction than violence. These views, however, do not explicitly tell whether or not Justin accepted Christian soldiers. In general, he does not have much to say about soldiers. Justin claims that "your Pilate," with the soldiers, was against Christ (1 Apol. 40.6). This is possibly an echo of the Johannine dualism where soldiers are against Christ and his followers. In another place, Justin compares the compensation given to soldiers and to persecuted Christians. Soldiers put their life in danger without any incorruptible compensation. Why, then, would the Christians not do the same if they get an eternal compensation (1 Apol. 39.5)? Eduard Lohse comments on this by saying that Christians are soldiers in a peculiar way ("Soldaten besonderer Art"). 251 Whether or not this peculiar art of soldiers can also pertain to an ordinary soldier is left open, however. Cadoux claims that Justin was against Christian participation in the army, but provides an explanation why there was no open antimilitarism. According to Cadoux, an open denial of military service would have ruined Justin's main purpose, to win toleration in the Empire. ${ }^{252}$ One might ask how Cadoux can know this. As there is no statement on the matter, I think that it is safer to leave Justin's view open. In any case, it is clear that military matters were not close to him. He belonged to the intellectual elite of his time, which had a negative or distant relationship in relation to such affairs.

After Justin we find similar slightly negative or distant views in many other Christian authors. Tatian (ca. 120-180) shared Justin's middle Platonist view that wars are inspired by demons (Oratio ad Graecos 19.2-4). It is claimed that

\footnotetext{
250 For Epictetus' view on state laws and rulers, see Huttunen 2009, 83-92.

251 Lohse 1990, 15.

252 Cadoux 1919, 103.
} 
he refused to follow military commands. ${ }^{253}$ This view is based on an incorrect understanding of the text and probably even on an incorrect translation in the Ante-Nicene Fathers:

I do not wish to be a king; I am not anxious to be rich; I decline mili-

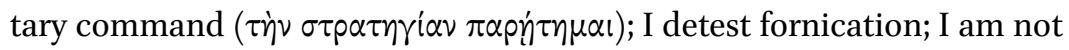
impelled by an insatiable love of gain to go to sea; I do not contend for chaplets; I am free from a mad thirst for fame; I despise death; I am superior to every kind of disease; grief does not consume my soul. Am I a slave, I endure servitude. Am I free, I do not make a boast of my good birth.

Tatian, Oratio ad Graecos 11.1; trans. ANF 2:69

This text is given in the context where Tatian denies that sinning is up to Fate. It is easily seen that, in the Stoic manner, he despises the value of every external thing. As I have noted above, for example, Epictetus claimed that external things are indifferent, but their use is not. People should not be emotionally dependent on any external thing, but treat them as God wants. ${ }^{254}$ Thus, declining "military command" means only that one is not automatically forced to follow the command. Moreover, why should one who despises such commands be a soldier? The case of angareia already shows that soldiers could command civilians. There is still one strong reason to doubt that Tatian is not speaking of the Christian attitude toward the army. The word $\sigma \tau \rho \alpha \tau \eta \gamma^{\prime} \alpha$ basically means praetorship or some other high office, which suits well in this particular context. ${ }^{255}$ It is probable that Tatian just denies the value of this kind of socially high position, insofar as he despises the position of king. Here, Tatian's reasoning is similar to that of Epictetus, who ridiculed an ex-slave for suffering in the campaigns in order to reach a high office (Disc. 4.1.39-40). However, Tatian does not combine the high office with warfare. Thus, I cannot conclude that Tatian was against Christian participation in the army. The issue is left open, which shows a distant relationship to these matters.

Athenagoras (ca. 130-190) claims that punishment in the hereafter is morally needed. Otherwise those robbers, rulers, and tyrants who have unjustly ( $\dot{\alpha} \delta i x \omega \varsigma)$ killed myriads are left without their due. Their crimes include, for example, razing cities unjustly ( $\alpha \dot{\delta}(x \omega \varsigma)$ ), burning houses along with their inhabitants, devastating a country, and destroying inhabitants of cities, peoples, and even an entire nation (Res. 19.7). Athenagoras seemingly refers to campaigns

253 Cadoux 1919, 103; Bainton 1946, 195; Ryan 1952, 17; Shean 2010, 91.

254 On the Stoic theory of value, see, e.g., Huttunen 20o9, 20-26.

255 For the meanings of $\sigma \tau \rho \alpha \tau \eta \gamma$ i $\alpha$, see Liddell, Scott, and Stuart 2011. 
that led to total destruction, and which are critically described by Tacitus: "To plunder, butcher, steal, these things they misname empire: they make a desolation and they call it peace" (Tacitus, Agricola 30.5; trans. Hutton and Peterson, LCL). However, Athenagoras uses the word 'unjustly' twice, indicating the violent acts he speaks of as being immoral. This raises the question of whether or not some violent acts are just. Cadoux notes that "Athenagoras instances the usages of unjust war" without further commentary. 256

In principle, Athenagoras may refer to the just war theory, as it was known to the Romans. According to Cicero, there is only one justified casus belli: "The only excuse, therefore, for going to war is that we may live in peace unharmed; and when the victory is won, we should spare those who have not been bloodthirsty and barbarous in their warfare" (Cicero, Off. 1.34-40; trans. Miller, LCL). The Emperor Augustus boasts that he waged wars in that manner: "I made peaceful the Alps from the region near the Ionian bay as far as the Tyrrhenian sea, but made war on no tribe unjustly ( $\dot{\alpha} \delta \dot{i}(\omega)$ )" (Augustus, Res Gestae 26.3; trans. Cooley). This text is found in three inscriptions, and it must have been widely known. In any case, it transmits the standard Roman propaganda of just war repeated later, for example, by Suetonius (Aug. 21.2). ${ }^{257}$ In the context of this political discourse, it seems probable that Athenagoras shared the Roman theory of just war. He only blamed those rulers and tyrants who waged unjust wars. His words are vague, as if he is generally not interested in warfare or armies. Athenagoras' attitude toward the military is distant, a stance which is characteristic of members of the Roman intellectual elite. ${ }^{258}$

Irenaeus (c. 130-202) - like Justin before him—thinks that Isaiah's (2:3-4) and Micah's (4:2-3) prophecies are fulfilled in the Christian proclamation that the nations beat their swords and war-lances into peaceful instruments and that "they are now unaccustomed to fighting, but when smitten, offer also the other cheek" (Haer. 4.34; trans. ANF 1:512). It is, of course, hyperbole to claim that nations no longer fought in Irenaeus' time. He must factually mean that Christian individuals do not fight. It is again unclear if "fighting" is a metaphor or not. A reference to the Sermon on the Mount gives the impression of personal quarrels between individuals. Complete peace will be attained only after

\footnotetext{
256 Cadoux 1919, 5 o.

257 Cooley 2009, 223.

258 In another passage, Athenagoras claims that Christians do not endure seeing killing, even

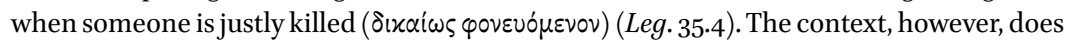
not refer to war or to the army. Athenagoras claims that rumors of killings in Christian gatherings are senseless, as Christians do not even attend the gladiatorial games. Thus, gazing upon just killings refers to what people watching gladiators do.
} 
the eschatological turn, ${ }^{259}$ when people are no longer like wild animals but tame ones:

[T] hose inflict no hurt at all who in the former time were, through their rapacity, like wild beasts in manners and disposition, both men and women; so much so that some of them were like wolves and lions, ravaging the weaker and warring on their equals; while the women (were like) leopards or asps, who slew, it may be, even their loved ones with deadly poisons, or by reason of lustful desire. (But now) coming together in one name they have acquired righteous habits by the grace of God, changing their wild and untamed nature. And this has come to pass already.

Epid. 61; trans. ROBINSON

As the last sentence reveals, Irenaeus thought that Christians had already changed from being like wild beasts into tame animals. His starting point is Isa 11:6-7; while Isaiah's text is not clearly metaphorical, Irenaeus' explanation is that animals refer to different kinds of people. The metaphorical use of animals is known from the philosophical tradition. For example, Epictetus says:260

It is because of this kinship with the flesh that those of us who incline toward it become like wolves, faithless and treacherous and hurtful, and others like lions, wild and savage and untamed.

Epictetus, Disc. 1.3.7; trans. Oldfather, LCL

Though Irenaeus speaks of "warring on their equals," this surely meant all kinds of violent quarrels. On the other hand, it is clear that there will be no wars after the eschatological turn. If Christians already live this peaceful life in this era, as Irenaeus assumes, it does logically include conscientious objection. This conclusion is not accepted by Jean-Michel Hornus, who refers to Haer. 5.24; ${ }^{261}$ here Irenaeus refers to Rom 13:4, where civil authorities are claimed to be agents of God's wrath. He advises Christians not to call the authorities into question when they punish wrong-doers legitimately. According to Hornus, this suggests that Christians could also be agents of God's wrath.

Hornus' interpretation, however, goes too far. Irenaeus probably thought that gentile authorities used the sword. He says that those who departed from

259 Sider $(2012,29-30)$ restricted the passage so that its eschatological character is no longer clear for the reader.

26o More analogies for Epictetus texts are referred to by Dobbin $(1998,88)$.

261 Hornus 1980, 65. 
God-clearly non-Christians—are "subjected to human authority, and kept under restraint by their laws," so that they can attain "some degree of justice, and exercise mutual forbearance through dread of the sword" (Haer. 5.24; trans. $A N F$ 1:552, italics added). Unlike Paul, Irenaeus speaks of the laws that hold society together, but behind these laws the sword looms large as the ultimate restraint. The wrathful sword and its use belong to their life, that is, to the life of the gentiles. I do not see here any hint of Christians using the sword. Irenaeus seems to acknowledge that authorities legitimately punish wrongdoers. Christians do not need such punishment, however, as they are tame animals instead of wild beasts. This seems to be in line with Justin and Epictetus, who also acknowledge civil punishments but prefer better, nonviolent means.

One can find more concrete information in the writings of Clement of Alexandria. There are several passing references to war and soldiers. ${ }^{262}$ Three of them are of greater interest. First, in a series of scattered passages from the Bible, Clement cites the exhortation of John the Baptist (Luke 3:14; Paed. 3.12.91). As I showed above, Luke did not question soldiers as such but only their malpractices. This seems to be Clement's stance, too, as he does not qualify the exhortation in any way. ${ }^{263}$ Another interesting passage is his injunction to use shoes. According to Clement, women should not go barefoot, whereas men can go barefoot, except in military service (Paed. 2.11.117). Ronald J. Sider comments on this: "Given the fact that Clement's whole book is devoted to describing how Christians should live, we should probably assume that Clement is thinking of Christians in the army."264

Sider's supposition is far from definitive, however, as Clement does not say this explicitly. His argumentation for soldiers wearing shoes is just a cryp-

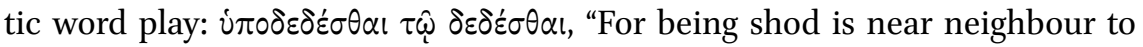
being bound" (trans. ANF 2:267). This seems to apply to any soldier, not just a Christian one. A passing reference to soldiers with word play can be a side comment, which does not necessarily refer to Christian soldiers. However, one passage does give more information, and it is sometimes presented as a witness that "Clement regarded military service as merely another occupation." 265 In the context, he states that human beings are created to have knowledge of God.

262 See a larger collection in Sider 2012, 32-42.

263 See also the Didascalia apostolorum (probably written in Syria around 230), which refers to the same exhortation in Luke (Sider 2012, 64-65).

264 Sider 2012, 37.

265 Helgeland 1979, 744; Cf. Harnack 1981, 75; Swift 1983, 52. 
Practise husbandry ( $\gamma \varepsilon \dot{\omega} \rho \gamma \varepsilon ı)$, we say, if you are a husbandman; but while you till your fields, know God. Sail the sea $\left(\pi \lambda \varepsilon \hat{i}_{l}\right)$, you who are devoted to navigation, yet call the whilst on the heavenly Pilot. Has knowledge taken hold of you while engaged in military service ( $\sigma \tau \rho \alpha \tau \varepsilon v o ́ \mu \varepsilon v o ́ v ~ \sigma \varepsilon ~ \varkappa \alpha \tau \varepsilon i \lambda \eta-$ $\varphi \varepsilon \vee \dot{\eta} \gamma \nu \hat{\omega} \sigma \iota \varsigma)$ ? Listen to the commander, who orders what is right.

Prot. 10.100; trans. ANF 2:200

I am hesitant to claim that this text presents military service as "merely another occupation." First, one may note that Clement speaks of those soldiers who have become Christians during their service. It is not just an occupation that a Christian takes. This may mirror the practice that a Christian should not enlist (Trad. ap. 16.9), though Clement does not express it clearly. ${ }^{266}$ Second, there is an interesting difference between the admonitions given to the soldiers and to the others. The commander who orders what is right surely denotes God, like the heavenly Pilot is God. ${ }^{267}$ Thus, the peasant and the sailor are admonished to do their work with God in their minds, but there is no specific injunction for soldiers to fulfill their military tasks. They are only admonished to listen to God. What this concretely means is left unsaid. While military service is somewhat problematic, it can be admitted that Clement is not an uncompromising antimilitarist.

The philosophically oriented Christian elite did not encounter the problem of militarism only in the Roman army but also in the Scripture. Marcion and some other theologians rejected the entire Old Testament, partly because of its violent and belligerent parts. Others justified the Scripture by allegorizing or by thinking that the times of such warfare were over and should be left in the past. ${ }^{268}$ The last stance we saw already in Epictetus, who could praise the Spartans' fighting in Thermopylae while his view of contemporary wars was negative. Clement of Alexandria bridged the histories of the Greco-Roman culture and the Old Testament by claiming that the Greeks learned all their skills from Moses_including military tactics and strategy (Strom. 1.24.158-160). The

266 Similarly, Rordorf 1969 , 113. In contrast, Helgeland $(1979,744)$ claims that "Clement never gave the slightest indication that enlistment would be a problem." The Apostolic Tradition is preserved in several versions and details vary between them (see Bradshaw, Johnson, and Phillips 2002, 89-9o). In each version, it prohibits the catechumen and baptized Christians from becoming soldiers. There were also limitations in accepting some high-ranking soldiers (thus interpreted by Bradshaw, Johnson, and Phillips 2002, 94) into the Christian community, while other soldiers are not mentioned at all. Seemingly those in military service who became Christians were usually not required to leave their occupation.

267 Sider 2012, 34. Cf. Rordorf 1969, 113.

268 Bainton 1946, 212. 
same church father, however, was dubious about the armies of his own time. Clement belonged to the intellectual elite of his time and shared their ambiguity vis-à-vis military issues.

All this religious hesitation in the face of military service seems confirmed by Celsus, who criticized Christianity in his book The True Word in 170-180. Celsus blamed Christians for not taking up arms for the emperor. Origen quotes his words:

For if all were to do the same as you, there would be nothing to prevent his being left in utter solitude and desertion, and the affairs of the earth would fall into the hands of the wildest and most lawless barbarians; and then there would no longer remain among men any of the glory of your religion or of the true wisdom.

Origen, Cels. 8.68; trans. ANF 4:665

According to Harnack, Celsus "confirms what we have assumed, that the church did not allow its faithful to serve in the military." Roland Bainton claims that Celsus "knew of no Christians who would accept military service." Origen, who wrote 70-80 years later, accepts Celsus' claim of Christians who did not enter the army. This is just intellectual discussion, however. Intellectuals discussed the ideas of the philosophically oriented Christian elite, not social facts. Many literate Christians despised or at least felt religious hesitation about military service, while other Christians lived their life within Roman society, including the army. Our first evidence of Christian soldiers after the New Testament writings come from Celsus' time. Next I will look at the nonintellectuals and some intellectual dissidents.

\subsubsection{Intellectuals and Other Christians}

Tertullian and Eusebius of Caesarea discuss Christian soldiers in Marcus Aurelius' "thundering legion," Legio XII Fulminata, which fought on the northern frontier in the 170s. Both authors refer to the so-called "rain miracle." The miracle has historical roots, as it is also described in gentile sources without any mention of Christians. ${ }^{269}$ The column of Marcus Aurelius represents two anomalous weather phenomena, the rain and the thunderbolt. ${ }^{270}$ The rain god

269 The most important ancient sources are Dio Cassius 72.8-10; Historia Augusta, M. Ant. 24.4; Tertullianus, Apol. 5.6; Eusebius, Hist. eccl. 5.5. Kovács (2009, 23-93) provides an extensive collection of the sources and commentaries on them.

270 On the incidents described in the column with an overview to the literary sources, see, e.g., Ferris 2009, 81-93. 
depicted on the column was a new figure in Roman iconography. The god does not correspond to Hermes Aerios, to whom the Roman sources attribute the miracle. ${ }^{271}$ Kovács assumes that "the creator of the visual message of the column evidently did not wish to identify the figure with any specific Roman god," and suggests that the rain god is an allegorical figure. ${ }^{272}$

Because the rain god is a totally new figure, one is tempted to see here a reference to a new divinity for the Romans, that is, the god of Christian worship. Tertullian attributes the rain to God, to whom Christian soldiers prayed in distress. Tertullian refers to what Marcus Aurelius himself would have written in a letter: "He bears his testimony that that Germanic drought was removed by the rains obtained through the prayers of the Christians who chanced to be fighting under him" (Tertullian, Apol. 5.6; trans. ANF 3:22). ${ }^{273}$ What imperial letter Tertullian has seen is unknown. ${ }^{274}$ However, he also mentions the rain miracle in Ad Scapulam 4.6, maintaining that it is a famous incident. While Tertullian's descriptions are short, they are the earliest preserved written sources. ${ }^{275}$ These testimonies come some decades after the incident. Eusebius is more generous with his account, telling that rain and thunder brought victory to the Roman army after the Christian soldiers kneeled and prayed for help (Hist. eccl. 5.5). Although Eusebius wrote in the fourth century, his words have some reliability, as he used earlier sources, gentile texts, Tertullian and-what is most interesting-Apollinaris, the bishop of Hierapolis in Phrygia, who was a contemporary of the campaign. Although one cannot exactly know what comes from Apollinaris, Eusebius seems to base his work on a source independent of any that has been preserved. ${ }^{276}$

John Helgeland points out that neither Apollinaris nor Tertullian give any hint that the Christian soldiers did something wrong. ${ }^{277}$ Shean reads this as a general acceptance of military service. ${ }^{278}$ I do not agree. One should keep in mind that Apollinaris and Tertullian wrote apologies for the emperor. In this context it is understandable that no critical stance toward the military would be expressed. They did not wish to raise any suspicion of disloyalty. As I later

271 Ferris 2009, 84.

272 Kovács 2009, 166-167.

273 Tertullian also mentions the incident in Scap. 4.6; ANF 3:107.

274 There is a letter from Marcus Aurelius to the Roman senate, but it seems to have been written in the 4th century (Helgeland 1979, 769; Kovács 2009, 113-121). The text of the letter is given, e.g., by ANF 1:187; see Kovács (2009, 51-53) and Snyder (2012, 140-142).

275 Pace Ferris $(2009,86,88)$ who claims that Dio Cassius provides the earliest writing in the first decades of the third century. Later, however, he reports that Tertullian wrote ca. 200.

276 Kovács 2009, 47-50.

277 Helgeland 1979, 773 .

278 Shean 2010, 191. 
show, Tertullian could also write on Christian soldiers in a totally different tone. Tertullian's (and possibly Apollinaris') critical stance, however, lends reliability to the information. There was no ideological need to invent stories of Christian soldiers. In sum, it seems a fact that there were Christians in Marcus' army. Legio XII Fulminata was recruited in Cappadocian Melitene, and it must have trained there rigorously before the campaign. Helgeland suggests that "Christian participation in the army at Melitene must have taken place long before 173 ,"279 when he dates the miraculous victory. This dating is not universally accepted, but all scholars place the rain miracle in the first years of the 170 . $^{280}$ Thus, there must have been Christians in the legion no later than the late 16 os.

The Christians of the "thundering legion" are the first Christian soldiers after those mentioned by the Gospel of Luke and Acts. It makes no difference whether the Christian soldiers referenced by Luke are historical. Luke's text proves that soldiers were welcome to join the Lucan communities. Since Luke wrote around 100, the "silent years" between Luke and the rain miracle comprise about seven decades. Is it credible that there was no continuity from the canonical writings of Luke to the times of the "thundering legion"? I would argue that we should not put too much weight on the philosophically oriented church fathers, as they did not cover the whole of Christianity of their time. The Gospel of Peter, the origin of which is before $150-190,{ }^{281}$ gives a very positive picture of soldiers, though it does not claim that they were Christians.

Through an analysis of The Infancy Gospel of Thomas, Helgeland has supported the idea that soldiers were accepted into Christian circles. Its picture of Jesus is less peaceful than that of the canonical gospels. This apocryphal gospel attracted the interest of less literate Christians, which brings Helgeland to conclude that "a study of the church fathers alone is likely to present a dangerously biased impression of the experience of the early church."282 Though The Infancy Gospel does not speak of Christian soldiers, it shows that the common Christians did not always share the ideals and values of the intellectual elite. ${ }^{283}$ Differences within the Christian communities on the educational level also

\footnotetext{
279 Helgeland 1979, 773.

280 Kovács 2009, 265-275.

281 Foster 2010, 172.

282 Helgeland 1979, 762-764. Sider (2012, 129-130) rightly criticizes Helgeland for confusing The Gospel of Thomas and The Infancy Gospel of Thomas. However, that does not weaken the point that The Infancy Gospel of Thomas indeed presents a more violent picture of Jesus than the canonical gospels.

283 On the differences between the literate elite and other Christians, see Shean 2010, 154-162.
} 
explain why some literary sources are so negative or hesitant toward military service, while other texts leak that Christians were soldiers.

I do not to claim that every literate Christian shared the hesitant or negative views of many philosophers. Otherwise one could not explain, for example, Luke's views. Later, Julius Africanus clearly differs from the philosophical church fathers; he is a deviant figure among the literate Christians of the beginning of the third century. That Julius shamelessly promoted the art of war embarrassed Cadoux, leading him to claim that Julius was only nominally a Christian and thus "represents no one but himself."284 In fact, he is a good reminder that the views of the church fathers did not represent the whole truth. Born in Aelia Capitolina some fifteen years after the Bar Kokhba revolt, Julius belonged to the high society of the eastern parts of the Empire. ${ }^{285} \mathrm{He}$ may have been an officer of Septimius Severus' army, but if not, he was at least well acquainted with military matters. ${ }^{286}$ This is evident from his book Kestoi, which he wrote during his stay in Rome. The book was aimed at insinuating himself into the good graces of Emperor Severus Alexander. ${ }^{287}$

Encyclopedic in scope, it is an assemblage of miscellaneous, practical advice about military ruses, armament, horse medicine, weights and measures, botany, antidotes, textual criticism, amulets, truth serums, hypnotics, aphrodisiacs, fertility drugs, and even family planning. Much of what survives from it is a disquieting catalogue of various methods of biological and chemical warfare. The tone is strident and merciless. Poison the food and water of the barbarians, Africanus urges, just as they try to poison us. ${ }^{288}$

The book belongs to the category of manuals that provided technical details supporting the Emperor's warfare. It is not without parallels, though its Christian origin is unique. ${ }^{289}$ Despite his more clearly Christian writings, Julius was a fringe figure in the Church. He "held no church office, formed no sect,

284 Cadoux 1919, 206-207.

285 Adler 2004, 521-522; Shean 2010, 193-194. Adler (2004, 531-534) denies that the court of Edessa was Christian, although the court had close relationships with Christians like Julius.

286 Adler 2004, 539.

287 Adler 2004, 540.

288 Adler 2004, 542.

289 Adler 2004, 543-544. 
had no school, taught no students, attracted no following."290 Hence, he did not belong to the philosophically oriented Christians. Yet, his figure reveals a side of early Christianity which is so easily forgotten in the shadow of the more antimilitaristic church fathers.

While most Christians never wrote a single word, there is fortunately archaeological evidence that points to the existence of Christian soldiers at the turn of the third century. Some scholars have counted funerary inscriptions as proof of this, but very few of the inscriptions are from the pre-Constantine period. Even fewer are from the first half of the third century or earlier. I comment on only two of the inscriptions, as they are early enough and seem to have a tie to Christianity. ${ }^{291}$ First, there is an inscription which commemorates the wife of a certain Cossutius serving in Septimius Severus' army. The text includes a date: April 10, 201.

$$
\begin{aligned}
& d(\text { is) m(anibus) Cossutius Eutyches Aureliae Romanae coniugikar(issimae) } \\
& \text { dulcis(simae) ben(e) m(erenti) fecit cum quo vix(it) ann(os) XXVIII } \\
& \text { secund(a) Parthica Sever(iana) Faviano Muc(iano) con(sulibus) III idus } \\
& \text { April(es). }
\end{aligned}
$$

To the gods and to the shades. Cossutius, spouse of Eutyche Aurelia, made this monument for his Roman spouse, dearest and sweetest, with whom he lived twenty-eight years, member of the Second Parthian Severan Legion, in the consulship of Favianus and Mucius, three days before the Ides of April. ${ }^{292}$

The identification with Christianity is seemingly based on the place of the inscription, not on the text itself. ${ }^{293}$ Actually, the text raises doubts about the identification of Cossutius as a Christian. First, there is no hint of Christianity in the text. Second, are the opening words of the text something which can be expected of a Christian? What are the "gods" that a Christian would refer to? Third, if we accept that the place of the inscription determines

\footnotetext{
290 Adler 2004, 547.

291 See, e.g., Hornus 1980, 118-122; Helgeland 1979, 791-793; Swift 1979, 862; Shean 2010, 183185. Sider $\left(2012,145^{-151}\right)$ gives a series of inscriptions. Among them is one from the year 217, which is sometimes supposed to be Christian because of the words "welcomed to God." Yet, because it is far from certain that this implies the Christian God (Sider 2012, 148), I leave this inscription aside.

292 Cf. CIL 6.32877; trans. Owen Evald in Sider 2012, 147.

293 Swift 1979, 826.
} 
that Eutyche was a Christian, what makes us suppose that Cossutius shared her faith? Thus, this inscription does not provide evidence of Christian soldiers.

Another interesting inscription is found in the Christian cemetery of Priscilla in Rome. Scholars have dated it to the end of the second century. Thus, it might be even earlier than the inscription cited above. ${ }^{294}$

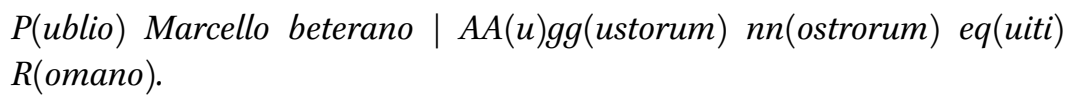
$R$ (omano).

To Publius Marcellus, a Roman knight, veteran of the army of our two emperors. ${ }^{295}$

Not even this is unambiguously an inscription of a Christian soldier. The deceased man is certainly a veteran, but the text does not tell whether or not he was a Christian during his active service. Scholars who normally comment on all the pre-Constantine inscriptions conclude that the very existence of these inscriptions proves the toleration of soldiers in the Christian communities. ${ }^{296}$ When looking only at these two inscriptions, however, such a conclusion must be made more carefully: there were possibly soldiers among the Christians around the year 200. What these funerary inscriptions show, at the very least, is that the social network of Christians reached into military life. It was acceptable to not prohibit military careers in the communities where the inscriptions were found. ${ }^{297}$ This is not much, but an expert of inscriptions would find more. Germane to my discussion, Ronald J. Sider writes that a new, up-to-date study on this topic would be very useful. ${ }^{298}$

Fortunately, we also have other archaeological evidence of Christian soldiers. In Dura-Europos, a town and military base in Syria, a home church has been discovered. ${ }^{299}$ The town was destroyed in 256 , so the church must be dated earlier than that. There was a dwelling of soldiers in the same city block as the church, as the Greek and Latin inscriptions prove. ${ }^{300}$ In the church, there are some Roman names in the inscriptions. ${ }^{301}$ One of these, Proclus, is found

\footnotetext{
294 Sider 2012, 146.

295 Cf. CIL 6.37273; trans. Owen Evald in Sider 2012, 147.

296 Bainton 1946, 193-194; Hornus 1980, 122; Swift 1979, 862; Shean 2010, 185.

297 Cf. Swift 1979, 862.

298 Sider 2012, 146.

299 For an overview of the church and the Christian community there, see Snyder 2003, 128134; MacMullen 2009, 1-10; Mell 2010, 33-105.

300 Mell 2010, 87 .

301 Mell 2010, 101.
} 
in a wall painting that presents the victory of David over Goliath. Otherwise, the name Proclus appears only in the military sources of Dura-Europos. The name in the painting indicates either the painter or the benefactor. ${ }^{302}$ Ulrich Mell has convincingly shown that the motif of David and Goliath belongs to the old Syrian baptismal ritual, ${ }^{303}$ but one can speculate whether it had a special appeal to soldiers. It seems probable that there was a Proclus among the Christians of Dura-Europos.

If the case of Christian soldiers is somewhat speculative in Dura-Europos, it is not in Megiddo. A Christian prayer hall at Megiddo has an unequivocal military character, as both its place and an inscription prove. The construction is dated around 230,304 which means that it is earlier than the house church in Dura-Europos. The prayer hall is situated in the immediacy of a Roman army camp. Besides the prayer hall, the building consists of dwellings of centurions and their families. There was also a bakery, which belonged to the army, as bread stamps used by the army were found there. ${ }^{305}$ Thus, it seems that the army owned the building. ${ }^{306}$ The floor of the prayer hall is decorated with four mosaic carpets situated around a stone table. All the carpets have geometrical figures. In addition, one carpet has two inscriptions and one carpet an inscription with a picture of two fishes, a tuna and a bass. ${ }^{307}$ The three inscriptions, written in Greek, prove that the prayer hall is a Christian construction. The carpet with the picture of fishes includes the following text:

Gaianus, also called Porphyrius, centurion, our brother ( $\dot{\alpha} \delta \varepsilon \lambda \varphi \partial \dot{\varsigma} \dot{\eta} \mu \hat{\omega} \nu)$, has made the pavement at his own expense as an act of liberality. Brutius has carried out the work. ${ }^{308}$

This text fits well with the picture of centurions from the gospels and other material. As I have shown above, centurions had economic resources, which

\footnotetext{
302 Mell 2010, 162.

303 Mell 2010, 169-173.

304 Tepper and Di Segni 20o6, 28, 50. The dating is debated (Adams 20o8, 64-66). Adams compares the construction with a post-Constantine building in Britain, where there is a chapel installed in one of the rooms. According to Adams, this similarity with the prayer hall in Megiddo "could perhaps lend weight to the view that the Megiddo church is a later (post-313 CE) Christian addition" (Adams 2008, 67). This evidence is very weak, however. A later survey on the site has not changed the dating (Tepper, David, and Adams 2016, 116). Tepper and Di Segni 2006, 24, 29-30, 45.

306 Tepper and Di Segni 2006, 50-51. The unit there was Legio VI Ferrata, which seems to have been present already at Hadrian's time (Tepper and Di Segni 2006, 14; Pollard and Berry 2012, 153-154).

307 Tepper and Di Segni 2006, 31-34.

308 Trans. Tepper and Di Segni 20o6, 34.
} 
made them appealing for the Christian communities. Gaianus could afford a mosaic construction. Though he is "our brother," this designation is not enough to prove that he was a Christian. This designation was used in Greco-Roman associations and in militarylife, especially among the adherents of Mithraism. ${ }^{309}$ The Christian character becomes plain in the other carpet, which includes two texts. The first indicates the donor of the stone table:

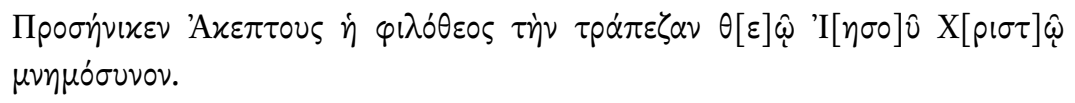
$\mu \nu \eta \mu o ́ \sigma 0 v o v$.

The God-loving Akeptous has offered the table to God Jesus Christ as a memorial. $^{310}$

The words "God Jesus Christ" unequivocally proves that the prayer hall is a Christian construction. Each of the sacred names appears as a standard abbreviation, which we know from papyri of the 3 rd-4th centuries. ${ }^{311}$ As the inscription dedicates the table to God Jesus Christ, it was probably used for the Eucharist. ${ }^{312}$ Yotam Tepper and Leah Di Segni interestingly point out that the word $\mu \nu \eta \mu \sigma^{\sigma} \sigma v v^{\prime}$ occurs three times in the New Testament (Matt. 26:13; Mark 14:9; Acts 10:4). In Acts, the word is used by an angel in speaking to Cornelius the centurion: "Your prayers and your alms have ascended as a memo-

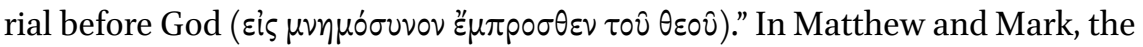
word occurs in the story of a woman anointing Jesus in Bethany. Jesus says that the incident should be told to the whole world in memory of her (zis $\mu \nu \eta \mu o ́ \sigma v v o v$ $\alpha \dot{v} \tau \hat{\varsigma}$ ). Tepper and Di Segni claim that in light of the anointing story, the word does not occur by chance in the inscription. There are also women in the other inscription of the same carpet. The inscription runs as follows:

Remember ( $\mu \nu \eta \mu \circ v \varepsilon \dot{\sigma} \sigma \tau \varepsilon)$ Primilla and Cyriaca and Dorothea, and moreover also Chreste. ${ }^{313}$

Tepper and Di Segni note that the formula is unusual, as the request is not addressed to God-which is usual in the memorial inscriptions-but to other

\footnotetext{
309 Harland 2005; Tepper and Di Segni 2006, 34-35.

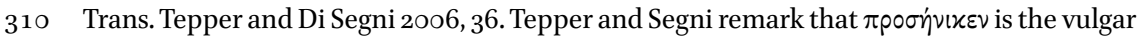

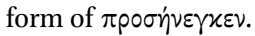

311 Tepper and Di Segni 2006, 36.

312 See Tepper and Di Segni $(2006,37)$, who note that the Greek word used in the inscription also occurs in Paul when he refers to the Eucharist (1 Cor 10:21).

313 Trans. Tepper and Di Segni 2006, 41.
} 
Christians. ${ }^{314}$ One is tempted to think that, as a woman, Akeptous wanted to be remembered like the other women mentioned in the carpet. In this interpretation, Akeptous would have erected the table for Christ so that it would also serve as a reminder of her. In the Scripture, there are also examples of a memorial ( $\mu \nu \eta \mu \delta$ ovvov) for people in cultic situations (cf. Lev. 23:24; Num. 17:5). This interpretation is anything but clear, however. The parallel between the woman in the New Testament story and Akeptous is not very close. The former does not offer a memorial, as Akeptous does. Instead, the story itself is a memorial of the woman for people. One should consider other interpretative options.

Was the table intended to remind the people of Christ or Christ of the people? As the table was probably used for the Eucharist, one can associate it with the idea that the Eucharist is celebrated in rememberance of Christ (1 Cor 11:24-25; Luke 22:19; Justin Martyr, 1 Apol. 66:3). In this reading the table would be a memorial of Christ for the Christians. This is, however, not very probable. First, in the traditionally transmitted eucharistic words the

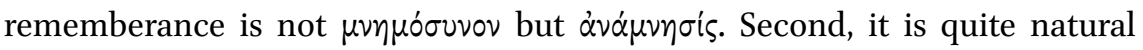
to understand the word $\mu \nu \eta \mu o ́ \sigma u v o v$ as a second object for the verb. ${ }^{315}$ Thus, the table should remind God Jesus Christ of something, probably of the local Christians. This idea comes close to the Eucharist prayer of Didache, which contains the petition "Remember ( $\mu \nu \eta \dot{\sigma} \sigma \eta \tau \tau)$ your church, O Lord" (Did. 10.5; trans. Ehrman, LCL). There are analogies for the use of $\mu \nu \eta \mu$ ó $0 v 0 v$ in this sense. In the story of Cornelius, prayers and alms are a memorial ( $\left.\mu \nu \eta \mu \sigma^{\sigma} \sigma \nu v^{\circ}\right)$ for God. The Book of Tobit speaks of prayers as a memorial ( $\mu \nu \eta \mu o ́ \sigma v v o v)$ before God (Tob 12:12; cf. Sir 50:16). The Septuagint provides analogies of cultic articles as a memorial ( $\mu \nu \eta \mu o ́ \sigma v v o v)$ for God (Exod 28:29; 30:16; Num 31:54). This use of $\mu \nu \eta \mu \sigma_{\sigma} \sigma v v^{2}$ suits quite well for the table, while the use of the word in the story of the anointing woman is more remote. I conclude that Akeptous erected the table to remind God Jesus Christ of the believers in the camp. In addition, the analogical use of $\mu \nu \eta \mu$ ó $\sigma v v^{2}$ in the story of Cornelius may have appealed to the Christians congregated in a building that belonged to the Roman army.

The Christian prayer hall in Megiddo is an unequivocal witness that there were Christians in the Roman army in the beginning of the third century. As the prayer hall is in the building owned by the army, Christians gathered

314 Tepper and Di Segni 2006, 42. Similar formulations are found in the church of Dura-Europos (Mell 2010, 16o-161). One could also ask, is it certain that the plural refers to Christians and not, for example, to the divine Father and Son? Justin Martyr already

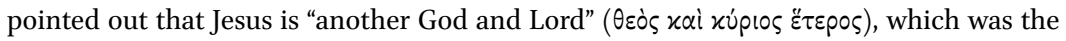
explanation for the occasional plural referring to God in the Scripture (Dial. 56.4; 62.1-4). That said, I do not know any Christian prayer with an address in the plural.

On two accusatives with one verb, see Smyth 1984, 362 . 
openly there and their faith was tolerated in the unit. Neither was the church in Dura-Europos a secret one; it was generally known. ${ }^{316}$ These facts fit well with the relative tolerance of Christianity in the beginning of the third century. A positive peak for the Christians was during the reign of Emperor Alexander Severus (r. 222-235). He is claimed to have kept Christ and Abraham among his household lares (Historia Augusta, Alex. Sev. 29.2). ${ }^{317}$ The emperor's mother played an important role in the administration (Historia Augusta, Alex. Sev. 14.7). Eusebius of Caesarea reports that she had Origen give her a lecture and that the emperor's household was largely Christian (Hist. Eccl. 6.21.3-4; 6.28). The sources may somewhat exaggerate the favor of Christianity in the court, but there was apparently a certain degree of peace. The existence of the prayer hall in a military area fits with this warmer period for Christians in the Empire. ${ }^{318}$

As Christianity did not belong to the official cults of the state, it was celebrated outside of the army camp. We do not know how the centurion Gaianus, "our brother," and other brothers in Legio vi Ferrata lived with the official cult. Neither do we know, for instance, how they reconciled the "gospel of peace" with their military profession. They apparently did not concern themselves so much with these issues, or at least they found a way to reconcile their profession with their faith. Tertullian, an educated intellectual Christian, provides more information in spite of the fact that he did not accept them.

\subsubsection{Tertullian's Antimilitarism Meets Christian Practice}

Tertullian is routinely presented as the pacifist in the early Church.Jean-Michel Hornus speaks of "Tertullian and other Christian ethicists," who rejected all compromise with the military. ${ }^{319}$ As Roland Bainton points out, "In the West, Tertullian was the most unambiguous when he said that 'Christ in disarming Peter ungirt every soldier." 320 Tertullian provides two basic arguments against Christian participation in the army. First, Christians are not allowed to spill blood and, second, the idolatry included as part of military service is strictly

316 Mell 2010, 81-82.

317 Historia Augusta, Alex. Sev. 43.6-7, 51.7-8 also reports of Alexander Severus' otherwise positive attitude toward Christianity. One can surely see here the tendency of a pagan author to propagate religious tolerance in the Theodosian Christian Empire at the end of the 4th century (Stertz 1977).

318 Adams $(2008,66)$ supposes that construction of the prayer hall would have invited a religious conflict, but in the political climate of Alexander Severus it was not automatically so. Alexander's successor Maximinus Thrax started persecutions, but these were limited to certain leaders of the Church (Eusebius, Hist. Eccl. 6.28). Later, Philip the Arab (r. 244-249) is reported to be a Christian (Hist. Eccl. 6.34), but this is also an exaggeration. However, his reign was evidently mild for the Christians (Pohlsander 1980). 
prohibited (Cor. 11; Idol. 19). ${ }^{321}$ While it is right to present Tertullian as an antimilitarist, he is not representative of the general Christian attitude. His own writings betray the fact that all Christians did not live up to his ideals. What we encounter again is the discrepancy between the views of the elite Christians and the reality among other Christians. For this reason, it is fruitful and illustrative to complete this chapter with a survey of Tertullian's writings.

Jerome claimed that Tertullian was the son of a centurion (Vir. ill. 53), but this information is not always taken as fully certain. ${ }^{322}$ One of the arguments for Tertullian's military background is his dense use of military parlance. ${ }^{323}$ "We were called to the warfare of the living God (ad militam Dei vivi) in our very response to the sacramental words (in sacramenti verba)" (Mart. 3; trans. $A N F$ 3:694), he proclaims in a manner that is not very unusual for him. ${ }^{324}$ One of the original meanings of sacramentum is military oath, to which Tertullian clearly refers here. However, the sheer existence of military metaphors does not require a military background. I earlier noted that the military metaphors in early Christianity have roots in the ancient philosophical tradition. One encounters military metaphors in Plato, Aristotle, Epictetus, and other philosophers. The same metaphors were present in the Latin literature. Seneca admonished: “vivere, Lucili, militare est (Ep. 96.5). In Apuleius' Metamorphoses, a priest of Isis tells that at the end of the initiation rite, Lucius, the main character of the novel, enlists himself "in this holy army (sanctae huic militiae), to whose oath of allegiance (sacramento) you were summoned not long ago" (Metam. 11.15; trans. Hanson, LCL). ${ }^{325}$ Pliny the Younger already spoke of the oath (sacramentum) among Christians (Ep. 10.96). He seemingly borrowed the word from the military parlance. ${ }^{326}$

Thus, military language as such betrays nothing of the background in the Christian congregation. It is more a question of its frequency than the simple occurrence of military metaphors. Tertullian used military parlance more densely than any other theologian of the early Church, ${ }^{327}$ but as an antimilitarist he framed the military concepts anew. These refer to a lifestyle which creates an alternative or even an opposition to the concrete military calling.

321 See also Rordorf 1969, 124; Gero 1970, 294-295; Shean 2010, 95-98. Helgeland (1979, 741) plays down the problem of bloodspilling in a questionable way. Although it is true that the biblical references Tertullian uses are not pacifistic, his way of using them is clearly against any bloodspilling that included war and the army.

322 On the scholarly discussion, see, e.g., Trilling 2004, 29-31.

323 Trilling 2004, 31, 6o.

324 On Tertullian's military parlance, see, e.g., Bähnk 2001, $5^{8}-76$.

325 Rordorf $(1969,134)$ refers to this and other parallels, which, as far as I see, are not so clear as this one.

326 Cook 2010, 209.

327 Cancik 2008, 273. 
"For what wars should we not be fit, not eager, even with unequal forces, we who so willingly yield ourselves to the sword, if in our religion (apud istam disciplinam) it were not counted better to be slain than to slay?" (Apol. 37; trans. ANF $3: 45) \cdot{ }^{328}$ Why, then, does Tertullian's writing have this strong military color? As Tertullian himself was an antimilitarist, is the parlance due to the influence of soldiers in the early Latin Church? According to Harnack, Tertullian's strong militaristic language is located in the tradition of Latin Christianity, which had social reasons for this tendency: "the military element was at times very strong in some of the earliest Latin congregations." ${ }^{329}$ Hubert Cancik notes that there is a difference between the intellectual and abstract character of the Greek theological concepts and the Latin terms derived from the administrative and the military sources. ${ }^{330}$ Cancik also points out that such military parlance preceded Tertullian. ${ }^{331}$

Some scholars have proposed that Tertullian wrote at the time of a growing role of the army in the Empire. The military offered more attractive opportunities than before, and, during Tertullian's time, the first Christian soldiers appeared-or at least their number grew immensely then. ${ }^{332}$ To claim that the first Christians appeared around the year 200 goes against the information available from the "thundering legion" in the 17os. Even Tertullian himself claims that Christians fought in this legion (Apol. 5.6). The military character of the Latin Christian concepts before Tertullian also points to Christian soldiers being no new phenomenon in Tertullian's time. On the other hand, it may be true that their number increased, raising ethical and theological questions. ${ }^{333}$ This creates a sensible background for Tertullian's heightened antimilitarism, which he unequivocally represented in his works De idolatria and De corona. The strength of the resistance against Christian participation in the army is thus related to the strength of the phenomenon in Latin Christianity that he resists.

328 The word disciplina is noteworthy: while the Christian religion is a kind of regimentation, it is not aimed at turning Christians into a disciplined army but into martyrs (Cancik 2008,275 ). To count it better to be slain than to slay is actually a variation on the Platonic principle: it is better to suffer wrong than do it (Gorg. 469c, 474b, 475e).

329 Harnack 1981, 54.

330 Cancik 2008, 269-271. Similarly also Bähnk 2001, 61.

331 Cancik 2008, 271-273.

332 Rordorf 1969, 109-110, 119-120; Gero 1970, 289, 291; Trilling 2004, 80. Rordorf denies the existence of Christian soldiers before Tertullian's time. Harnack (1981, 84-85), in contrast, claims that the credit of the army was diminishing. This may be true only of the literate elite, to which Harnack refers.

333 Rordorf $(1969,107$ n. 4, 118) claims that Tertullian refers to the contemporary discussion on soldiers in Idol. 19.1. As Rordorf openly states, this interpretation is not entirely unequivocal. 
If Tertullian was a rigorous antimilitarist, why does he not criticize the Christian soldiers in the Apologeticum? Instead he presents them as a proof of Christian loyalty to the Empire. He says that Christians fill "cities, islands, fortresses (castella), towns, market-places, the very camp (castra ipsa), tribes, companies (decurias), palace, senate, forum" (Apol. 37; trans. ANF 3:45). A common view is that Tertullian's attitude developed from the tolerant views in the Apologeticum into more rigorous ones. ${ }^{34}$ This supposition, however, assumes a certain chronology of the works that is hardly clear. ${ }^{335}$ Actually, the differences between Tertullian's views in the books mentioned above should not be exaggerated. The problem lies in the Apologeticum itself. Immediately after presenting Christians in every area of the society, the army included, he continues by saying — as we saw above — that according to the disciplina Christians prefer to be slain than to slay!

One can try to harmonize Tertullian's view by a reference to the paramilitary tasks of the army. A soldier could have tasks that were not military in the full sense of the word. Shean notes that "it was possible for a Christian to serve in the army without violating any of the pacifist prohibitions against killing."336 Unfortunately, this reading is out of place. As we have seen, in the Apologeticum he reported on Christian soldiers of the "thundering legion" on the northern front. This can mean nothing but fighting men. The real reason for Tertullian's ambivalence seems to be rhetorical. When writing an apology on behalf of all Christians to his non-Christian audience, he toned down his criticism of Christian soldiers. The discrepancy between his views and the conduct of his fellow Christians became part of his own treatise. Writing the De idolatria and De corona for his fellow Christians, he openly expresses his antimilitaristic conviction. ${ }^{337}$ Adolf Harnack put this bluntly, "We cannot exonerate this hotblooded man from the charge of keeping two sets of books." ${ }^{338}$

The De idolatria rigidly rejects any service in the army. In the treatise, Tertullian discusses different cases where a Christian might encounter idolatry. Military matters are treated in a passage after he has discussed the idolatrous clothing and ornaments required by public offices, which are unsuitable for a Christian (Idol. 17-18). Tertullian admits that rank-and-file soldiers can avoid

334 Gero 1970, 291-293; Shean 2010, 95.

335 On the scholarly discussion, see Bähnk 2001, 12 n. 11. Trilling (2004, 209-211) gives Harnack's chronology (orig. 1904) and T. D. Barnes' chronology (orig. 1971): both assume that the Apologeticum was written around 197. Harnack says that both De idolatria and De corona were written between the years 208-212, while Barnes dates De idolatria to 196-197 and De corona to 208.

336 Shean 2010, 96. Similarly Gero 1970, 292.

337 Cf. Bähnk 2001, 70 n. 125.

338 Harnack 1981, 77. See also Dunn 2015, 100-101, 103. 
idolatry, and then he turns to other arguments in order to rebut Christian participation in the army:

But now inquiry is made about this point, whether a believer may turn himself unto military service, and whether the military may be admitted unto the faith, even the rank and file, or each inferior grade, to whom there is no necessity for taking part in sacrifices or capital punishments. There is no agreement between the divine and the human sacrament (sacramento divino et humano), the standard of Christ and the standard of the devil, the camp of light and the camp of darkness. One soul cannot be due to two masters - God and Caesar. And yet Moses carried a rod, and Aaron wore a buckle, and John (Baptist) is girt with leather and Joshua the son of Nun leads a line of march; and the People warred: if it pleases you to sport with the subject. But how will a Christian man war, nay, how will he serve even in peace, without a sword, which the Lord has taken away? For albeit soldiers had come unto John, and had received the formula of their rule; albeit, likewise, a centurion had believed; still the Lord afterward, in disarming Peter, unbelted every soldier. No dress is lawful among us, if assigned to any unlawful action.

Idol. 19; trans. ANF 3:73

After illustrating the incompatibility of Christian and military callings, Tertullian suddenly turns the discussion to clothing: Moses' rod (Exod 4:2; 17:5) is associated with the rod (virga) of the centurion, Aaron's buckle (Exod 28:12; cf. 1 Macc 14:44) with the buckle (fibula) of the tribuni militum, and John the Baptist's belt (lorum) with the girdle worn by soldiers. ${ }^{339}$ Moreover, Joshua led the army and "the People" (i.e., Israelites) waged war. How can it thus be against Christian faith to serve in the army? ${ }^{340}$ John the Baptist accepted soldiers, as Luke reports, and the centurion of Capernaum believed without receiving an admonition to leave his office. ${ }^{341}$ These references seem to be arguments that some Christians have presented for the acceptance of military service. ${ }^{342}$ Tertullian shrugs off these scriptural proofs by claiming that the disarming of Peter in Gethsemane bears a principal message and, being a later incident, is more authoritative than the earlier ones. "A rather artful proof," Harnack

\footnotetext{
339 Waszink and van Winden 1987, 273.

340 Instead of "the People" (populus), Waszink and van Winden $(1987,62-63,267-269)$ read "Peter" (Petrus), which makes understandable the following claim of a joke. Tertullian is probably thinking of Peter using the sword in Gethsemane.

341 Tertullian cannot mean Cornelius the centurion, as he presumes that the centurion believed before Jesus' passion.

342 Harnack 1981, 77.
} 
ironically states, continuing: "The centurion from Caesarea is also forgotten, probably intentionally." Harnack rightly points out, however, that Tertullian is basically not pondering single scriptural proofs. Instead, there is a basic conviction that military service belongs to the realm of the devil. ${ }^{343}$ This is surely attested to by the idolatrous army religion.

This discussion of girdles or such things seems to have little to do with idolatry. Tertullian seemingly detours, as he must admit that the rank and file can avoid idolatry; their case must be treated with other arguments. As the end of the passage shows, Tertullian reasons that a soldier's dress is indeed connected to idolatry. In that way, the rank and file also participated in idolatry. Helgeland recalls the significance of clothing in the religious festivals of the army: every soldier had to wear formal dress on these situations. According to Helgeland, idolatry is the basic problem for Tertullian, not the military calling as such. ${ }^{344}$ This is partly true. Idolatrous clothing was the issue in the previous passage, and Tertullian returns to it at the end of this passage. Still, Tertullian's negative attitude toward soldiers does not wholly rest in idolatry. Killing is also a problematic issue, as the references to capital punishment and the disarming of Peter indicate. ${ }^{345}$

In De idolatria, Tertullian does not directly write about Christian soldiers. However, some arguments for the permissibility of Christian military service betrays their presence in the army. While there is surely an overstatement in the Apologeticum that Christians "fill" (implevimus) fortresses, camps, and companies, it certainly contains some truth: there really were Christians in the army. ${ }^{346}$ This is attested to by Tertullian's De Corona, which opens with an incident in the nuncupatio votorum, one of the several religious ceremonies performed in the army. This ceremony, held annually on January 3 rd, included the crowning of soldiers and a recitation of the military oath (sacramentum). ${ }^{347}$ This particular year, the soldiers also received a cash bonus:

Very lately it happened thus: while the bounty of our most excellent emperors was dispensed in the camp, the soldiers, laurel-crowned, were

343 Harnack 1981, 78.

344 Helgeland 1979, 739-740.

345 Quite similarly Sider 2012, 5 o.

346 In the same context, he claims that the majority of the inhabitants in the cities are Christians. This is without doubt an overstatement. See also Gero 1970, 292. In Apol 42 (trans. ANF 3:49), Tertullian says: "We sail with you, and fight with you, and till the ground with you." Gero (1970, 291-292) philologically discusses this passage, but concludes that actual military service cannot be ruled out.

347 Kossmann 2008, 135-136, 145-146. Otherwise, the oath was recited after enlisting and on the anniversary of the emperor's ascension to power (Helgeland 1979, 739). 
approaching. One of them, more a soldier of God, more stedfast than the rest of his brethren, who had imagined that they could serve two masters, his head alone uncovered, the useless crown in his hand-already even by that peculiarity known to every one as a Christian — was nobly conspicuous.

Cor. 1; trans. ANF 3:93

The opening words reveal that the main character had Christian brothers in arms who did not deny the laurel. Tertullian blames them, but also reports their arguments:

Thereafter adverse judgments began to be passed upon his conductwhether on the part of Christians I do not know, for those of the heathen are not different-as if he were headstrong and rash, and too eager to die, because, in being taken to task about a mere matter of dress, he brought trouble on the bearers of the Name. [...] they murmur that a peace so good and long is endangered for them. [...] they put forth also the objection-But where are we forbidden to be crowned?

Cor. 1; trans. ANF 3:93

Tertullian continues to address the question of forbidden laurels, but later opens his argumentation against all military service in Cor. 11-12. His strategy is to develop with examples the basic notion in the opening words: Christian soldiers try to serve two masters when adding a human oath to the divine one, ${ }^{348}$ keeping watch for others than Christ and so on: "The very carrying of the name over from the camp of light to the camp of darkness is a violation" (Cor. 11; trans. ANF 3:100). In addition to idolatry, killing is against the law of Christ, who proclaimed that those who take up the sword will perish by the sword. Moreover, a Christian soldier can be laureled after a victorious campaign against barbarians, which includes killing and, what is even worse, killing of fellow-Christians: "Is the laurel of the triumph made of leaves, or of corpses? Is it adorned with ribbons, or with tombs? Is it bedewed with ointments, or with the tears of wives and mothers? It may be of some Christians too; for Christ is also among the barbarians" (Cor. 12, ANF 3:101).

348 See also Cor. 12 (trans. ANF 3:101): "Lo! the yearly public pronouncing of vows, what does that bear on its face to be? It takes place first in the part of the camp where the general's tent is, and then in the temples. In addition to the places, observe the words also: 'We vow that you, O Jupiter, will then have an ox with gold-decorated horns.' What does the utterance mean? Without a doubt the denial (of Christ). Albeit the Christian says nothing in these places with the mouth, he makes his response by having the crown on his head." 
Unlike in De idolatria, in De corona Tertullian reluctantly finds room for Christian soldiers. Now he mentions not only the soldiers, which John the Baptist encountered, and the centurion of Capernaum - like in De idolatriabut also Cornelius. Tertullian consequently reasons: "Of course, if faith comes later, and finds any preoccupied with military service, their case is different" but only if they can "avoid offending God," which Tertullian seems to regard as being very difficult (Cor. 11). In allowing military service for those who were baptized when serving in the army, Tertullian goes along with Apostolic Tradition $16.9 .{ }^{349}$ Still, he is quite skeptical about whether a Christian can serve in the army without "quibbling" over his faith. He argues that a soldier has no special liberties in his Christian conduct. The necessities of military life allow for no exception to the normal Christian faith and morality (Cor. 11). Seemingly, some have allowed exceptions because of the necessities, but Tertullian has a profoundly contrary view. If there is any necessity, it is the necessity to suffer and die because of faith. ${ }^{350} \mathrm{He}$ remarks with contempt on the reaction of his fellow Christians when they saw one refusing the military crown:

They murmur that the peace so good and long is endangered for them. Nor do I doubt that some are already turning their back on the Scriptures, are making ready their luggage, are equipped for flight from city to city; for that is all of the gospel they care to remember. I know, too, their pastors are lions in peace, deer in the fight."

Cor. 1; trans. ANF 3:93

The refusing soldier put away his sword and military dress, and thus he was "equipped in the apostle's armour" (Eph 6:11-17) to fight the spiritual fight so that he would receive "the white crown of martyrdom" worthier of other crowns (Cor. 1; trans. ANF 3:93). ${ }^{351}$ Yet, Harnack doubts that the soldier was as exemplary a martyr as Tertullian claims. Harnack sharply questions why, for instance, the soldier suddenly refused to take the crown but has "not resisted military authority before on any of a hundred other occasions." ${ }^{352}$ Harnack points out that Tertullian makes a comparison with worshipers of Mithras in the closing section of the treatise (Cor. 15; trans. ANF 3:103). They had the liberty to be uncrowned, as they had refused it already in their rites, stating:

349 See the discussion above on Clement of Alexandria.

35 O Bähnk 2001, 71-76. Bähnk speaks of Tertullian's other treatises, but clearly there are similar ideas in De corona. See also Dunn 2015, 99.

351 Bähnk 2001, 69-70.

$35^{2}$ Harnack 1981, 83. 
"Mithras is my crown." ${ }^{353}$ Harnack concludes that Tertullian's hero actually requires the same freedom of religion as Mithraists: "It is a symptom of the increased self-consciousness of the Christians (especially those in the army) as a religious group distinct from others. Apparently this Christian soldier did not at all want to demonstrate that Christian service and military service were irreconcilable." 354

The reader must distinguish between the soldier's protest as a historical phenomenon and the interpretation Tertullian gave to it. It was Tertullian, who — as an intellectual — felt aversion toward military life and made this soldier into a hero of his own antimilitarism. This reveals his connections to the philosophical elite of his time, although he also maintained a certain distance. ${ }^{355}$ It is well known that Tertullian rhetorically rejected philosophy as Athens, which should have nothing to do with the Christian truth of Jerusalem (Praescr. 7). Still, he wrote a remarkable text, De pallio, which is an encomium on the philosopher's mantle that he had embraced. Tertullian says that his Christianity is "a better philosophy" (Pall. 6; trans. ANF 4:12); this simultaneously indicates a connection to and taking distance from "ordinary" philosophy. In philosophical terms, Tertullian's deep disgust toward idolatry is surely unique, though there were reserved attitudes among philosophers, too. ${ }^{356}$ For him, idolatry was the clearest reason to reject military service. Yet, he also thought that killing was against Christian morality. This reason comes closer to the philosophers, who felt disgust toward violence and violent means of ruling. In De pallio, Tertullian allows the philosopher's mantle to list public offices where it does not serve, for example: "no judge, no soldier (non milito), no king" (Pall. 5; trans. ANF. 4:11). It is symptomatic that it is just the philosopher's mantle that utters this. As a Christian intellectual, Tertullian shared the antimilitaristic ethos of his pagan peers.

\subsection{Conclusions}

I started the last section's discussion on military metaphors in order to ask whether they tell something about soldiers among the Christians. The result was mainly negative. However, the lengthy discussion was necessary to dismiss

353 This ceremony belongs to the initiation of the grade of miles (soldier). See Merkelbach $1984,95^{-96 .}$

354 Harnack 1981, 83.

355 Cf. Trilling 2004, $36-38$.

356 For example, Epictetus ridicules the desire to see Phidias' statue of Zeus when Zeus is everywhere (Disc. 1.6.24; Huttunen 2009, 39). See also Goulet-Cazé's article (1996) on Cynics and their views on religion and van Kooten's $(2008,347-354)$ description of Roman ideas of the aniconic cult. 
the idea that repeated military metaphors necessarily imply the existence of Christian soldiers. I showed that these metaphors belonged to the standard philosphical parlance of the day and were used also by persons with antimilitaristic attitudes. Only 1 Clement seemed to suggest more than this.

In the previous section I pointed out an antimilitaristic tendency in the Gospel of John. I showed that this tendency finds its home in the writings of the early Christian theologians, Tertullian being the most prominent Christian antimilitarist. The antimilitaristic tendency was part and parcel of the intellectual ethos of the time. Antimilitarism was characteristic not only of the Christian theologians, but also their philosophical pagan peers. While there were exceptions among Christian theologians, like Julius Africanus, most written sources reflect antimilitarism or at least a distant attitude to military issues. One should not read these sources as the Christian statement, however. The reality was more heterogenous. This looms in the antimilitaristic writings, too. While being an uncompromising antimilitarist, Tertullian speaks of Christian soldiers. In his in-group polemics he criticizes them, but in his apologetics for a non-Christian audience, these same soldiers are presented as a proof of Christian loyalty toward Roman society. The excavations in Dura-Europos and Megiddo suggest that some soldiers were quite openly Christians in the first decades of the third century. Tertullian's De Corona, despite its antimilitarism, betrays the same fact from ca. $200 \mathrm{CE}$. The number of Christians seems to have been high enough to require some sort of recognition and freedom from the state cult.

The increasing need to recognize Christians led not only to granting of recognition but also intensified periods of persecution, that is, until the Constantinian turn in the next century. The Decian persecution in the $250 \mathrm{~s}$ seems to have been the result of the rising importance of Christianity in Roman society. ${ }^{357}$ However, these persecutions do not make up the whole picture of Christians in Roman society. The remains of a prayer hall in Megiddo suggest a considerable degree of toleration or recognition of Christians from the side of the Roman army from the beginning of the third century. At the same time, many Christians granted recognition to the the Roman army by participating in its structures. While admittedly there was an antimilitaristic trait among the early Christians, which Tertullian clearly represents, his antimilitarism does not represent the whole truth of the relationship between early Christianity and the Roman army, since Tertullian had brothers in arms.

357 Rives 1999, 151. 